UNIVERSIDADE DE SÃo PAULO

INSTITUTO DE QUÍMICA

\title{
HIPERHOMOCISTEINEMIA E O RISCO CARDIOVASCULAR
}

GANNABATHULA SREE VANI

Tese de Doutorado

ORIENTADORA

PROFA. DRA. VIRGINIA BERLANGA CAMPOS JUNQUEIRA

SÃO PAULO

13.05.2002 
Ficha Catalográfica

Elaborada pela Divisão de Biblioteca e

Documentação do Conjunto das Químicas da USP.

\section{Gannabathula, Sree Vani}

G198h Hiperhomocisteinemia e o risco cardiovascular /

Sree Vani Gannabathula. -- São Paulo, 2002.

$130 \mathrm{p}$

Tese (doutorado) - Instituto de Química da Universidade de São Paulo. Departamento de Bioquimica.

Orientador : Junqueira, Virgínia Berlanga Campos

1. Vitamina : Bioquímica 2. Aminoácido : Metabolismo 3. Doenças cardiovasculares I. T. II. Junqueira, Virginia Berlanga Campos, orientador. 


\section{“Hiperhomocisteinemia e o Risco Cardiovascular"}

\section{GANNABATHULA SREE VANI}

Tese de Doutorado submetida ao Instituto de Química da Universidade de São Paulo como parte dos requisitos necessários à obtenção do grau de Doutor em Ciências - Área: Bioquímica.

Aprovada por:

Profa. Dra. VIRGÍNIA BERLANGA CAMPOS JUNQUEIRA

IQ - USP

(Orientadora e Presidente)

\begin{tabular}{c} 
Prof. Dr. WALTER COLLI \\
IQ - USP \\
\hline Profa. Dra. DULCINÉIA SAES PARRA ABDALLA \\
FCF - USP \\
\hline Profa. Dra. ANA CAMPA \\
FCF - USP
\end{tabular}

Prof. Dr. LUIZ ROBERTO RAMOS

UNIFESP

13 DE MAIO 2002. 
"Aos meus amados pais, a quem devo todas as minhas conquistas.... que apesar de não estarem mais fisicamente presentes, sempre estiveram ao meu lado em todos os momentos, dificeis e alegres, $e$ para sempre permanecerão vivos no fundo do meu coração".

"In memory of my 6eloved parents who are responsible for all my achievements, ... although are not present in this world anymore, have always 6een present in all the difficult and happy moments of my life. They will remain for ever deep inside my heart". 
"A vida é um jogo no qual as regras mudam constantemente; nada estraga mais um jogo do que aqueles que o levam a sério".

$G$,

Você, com seu amor, compreensão e respeito, soube me ajudar nos momentos mais dificeis. Te amo.

Aos meus amados filhos, sentido da minha vida, que aceitaram tantos sacrifícios e pacientemente esperam pela minha atenção.

Aos meus sogros, que tanto me incentivaram nessa minha caminhada.

Life is a game in which the rules are constantly changing; nothing spoils a game more than those who take it seriously.

G,

Your love, understanding and respect, always helped me in the most difficult moments of my life. Love $u$

To my loving kids, meaning of my life, who accepted so many sacrifices and patiently wait for my attention.

My in laws (Mr.Govinda Rao \& Mrs. Lakshmi Kantamma), Who gave me lots of incentive to conquer this step. 
Chefe( Prof. Dr. Edson Rodrigues):

Se houvesse mais pessoas como o senfor, o mundo seria bem

Melhor.

Meus irmãos e sister in laws, parte da minfa vida que de alguma maneira contribuiram para as minhas vitórias 
$\mathcal{N a ̃ o ~ 6 a s t a ~ c o n q u i s t a r ~ a ~ s a b e d o r i a , ~ e ́ ~ p r e c i s o ~ u s a ́ - l a . ~}$

$\grave{A} \mathcal{V} i$,

Que com sua sabedoria soube guiar e ensinar tudo que é essencial. Obrigada pela oportunidade e amizade. 


\section{AGRADECIMENTOS}

Ao Prof. Dr. Luiz Roberto Ramos, por acreditar em nós e toda ajuda indispensável na hora de decifrar os dados.

Aos participantes deste estudo, voluntários urbanos e rurais, sem os quais não seria possivel realizar este trabalho. Obrigado a todos.

Aos amigos e colegas que trabalharam no laboratório, Leandro Giavarotti, Ligia Azzalis, Ligia Gomes, Sandra Chan, Sandra Poppe, André Fonseca, Adriana carvalho, Alessandra F.Lima, Alcione Moscardi e Maria Antonietta Leitão, meus sinceros agradecimentos.

A Alessandro de Grande, por seu importante auxilio na etapa final.

Aos Amigos do Laboratório VITAE, Luciano e Tania Rodrigues, que pacientemente me auxiliaram a entender a cromatografia líquida.

À grande Adri, esteja onde você estiver, estará sempre nas nossas lembranças.

Ao $\operatorname{Dr}$ Clóvis A. Peres e Alexandre Shinzato, pelo auxílio durante a análise estatística.

À Andréa L. Oliveira e Silva da Análise, por toda boa vontade durante as dosagem das vitaminas

À Dr. Vania d' Almeida e ao Allan, pelos momentos gostosos e pelo o trabalho conjunto nas determinações de homocisteina.

À equipe da pós-graduação da IQ-USP, pela boa vontade e atenção prestada durante todos estes anos.

Às Profa. Dra. Ana Campa e Profa. Dra. Dulcineia Abdalla, da Faculdade de Ciências Farmacêuticas da USP e Profa Dra. Marisa de Medeiros e Prof. Dr. Pio Colepicolo, do Instituto de Química da USP, pelo incentivo e amizade.

À Prof. Ms. Angela Maria S. Mattos Pinto da UNITAU, pela compreensão e auxilio nos momentos difíceis.

Ao pessoal do Hemocentro - USF, pelo auxilio na coleta de sangue (especialmente durante fins de semanas) dos voluntários urbanos e rurais .

À Carmem de Luna Yelisetty, amiga e irmã, pela ajuda nas coletas, amizade e revisão do testo.

Àlê pelo auxilio na hora de dosagem dos lipídeos. 
À Karin Somon Giavarotti, ser amiga nos momentos negros é dom de poucos, desejo muito sucesso.

À D. Vitória, pela sua atenção.

Às meninas do laboratório de bioquímica- UNITAU, que de várias maneiras me ajudaram.

Ao CNPq, FAPESP, UNITAU, USF e Análise Produtos e Serviços para Laboratório LTDA, pelo apoio financeiro para a realização deste trabalho.

Os meus sinceros agradecimentos a todos que se fizeram presentes, voluntariamente, no desenvolvimento deste trabalho. 


\section{RES U M O}

Nível elevado de homocisteína (Hcy) no plasma é considerado fator de risco de doença cardiovascular. Consumo reduzido de vitaminas $B_{6}, B_{12}$ e ácido fólico tem sido relacionado com hiperhomocisteinemia. O objetivo desse estudo foi verificar o consumo de vitaminas $B_{6}, B_{12}$ e ácido fólico nas populações urbana e rural, bem como a correlação dos níveis plasmáticos dessas vitaminas com os níveis plasmáticos de Hcy. Também determinamos os níveis séricos de lipídeos e avaliamos o risco cardiovascular das populações frente a hiperlipemia. O consumo de $B_{6}$ e ácido fólico é maior na população urbana, com $p=0,00$ e $p=0,04$ respectivamente, sendo o consumo de $B_{12}$ maior na população rural, com $p=0,47$. As correlações são significativamente negativa entre Hcy e as vitaminas $\mathrm{B}_{12}$ e ácido fólico. A população rural apresenta Hcy com valor médio de $16,5 \pm 9,2 \mu \mathrm{mol} / \mathrm{L}$, classificada como hiperhomocisteinemia moderada, e a população urbana $12,8 \pm 5,5 \mu \mathrm{mol} / \mathrm{L}$, o qual está dentro da faixa de referência. $\mathrm{O}$ valor médio de LDL sérica é maior na população urbana $(3,4 \pm 0,8 \mathrm{mmol} / \mathrm{L})$ do que na população rural $(2,8 \pm 0,9 \mathrm{mmol} / \mathrm{L})$, com valor de $p=0,00$. Como fator de risco cardiovascular, consideramos Hcy plasmática $>14 \mu \mathrm{mol} / \mathrm{L}$ e LDL sérica $>3,38 \mathrm{~m}$ mol/L. Neste caso, $41,4 \%$ da população rural e $7,4 \%$ população urbana apresentam Hcy maior que $14 \mu \mathrm{mol} / \mathrm{L}$. O inverso ocorre em relação a LDL, onde $43,2 \%$ da população urbana e $11 \%$ na população rural apresentam níveis acima de $3,38 \mathrm{mmol} / \mathrm{L}$. Concluímos que o risco cardiovascular decorrente de hiperhomocisteinemia é maior na população rural que na urbana e este risco poderia reduzir mediante o consumo de vitaminas. 


\section{Abstract}

\section{ABSTRACT}

Elevated levels of plasma homocysteine (Hcy) are considered a risk factor for cardiovascular diseases. Low intake of vitamins $B_{6}, B_{12}$ and folic acid have been related to hyperhomocysteinemia. The purpose of the present study is to determine the consumption of the vitamins $B_{6}, B_{12}$ and folic acid in two Brazilian urban and rural populations, along with the plasmatic levels of these vitamins and plasmatic homocysteine. In addition, the serum levels of lipids have been determined to evaluate the cardiovascular risk in the two populations regarding their hyperlipidemic comdition. The consumption of $\mathrm{B}_{6}$ and folic acid is higher in the urban population $(p=0.00$ and $p=0.04$ respectively), while the consumption of $B_{12}$ is not significantly different $(p=0.47)$. There is a negative correlation between $\mathrm{B}_{12}$ and folic acid with Hcy. The rural population shows mean Hcy value of $16.5 \pm 9.2 \mu \mathrm{mol} / \mathrm{L}$ and is classified as having moderate hyperhomocysteinemia, while for the urban population, the mean value is $12.8 \pm 5.5 \mu \mathrm{mol} / \mathrm{L}$ and is well within the normal range. The mean value of the serum LDL is higher in the urban population $(3.4 \pm 0.8 \mathrm{mmol} / \mathrm{L})$ compared to the rural population $(2.8 \pm 0.9 \mathrm{mmo} / \mathrm{L})$ with a significance of $p=0.00$. Plasma Hcy values $>14 \mu \mathrm{mol} / \mathrm{L}$ and serum LDL $>3.38 \mathrm{mmol} / \mathrm{L}$ were considered as the risk factors for cardiovascular disease. With in the reference values, $41.4 \%$ of the rural population and $7.4 \%$ of the urban population show a Hcy as a risk factor. For LDL, the inverse is true, i.e $43.2 \%$ of urban and $11 \%$ of the rural population are at risk. We conclude that the cardiovascular risk arising from hyperhomocysteinemia is higher in the rural population and that this can be reduced by increased consumption of vitamins. 


\section{ABREVIATURAS}

\begin{tabular}{|c|c|}
\hline BHMT & Betaina-homocisteina metiltransferase \\
\hline $\mathrm{B}_{6}$ & Piridoxal fosfato \\
\hline $\mathrm{B}_{12}$ & Cobalamina \\
\hline CBS & Cistationina Beta-Sintetase \\
\hline $\mathrm{CIS}$ & Centro de Informática em Saúde \\
\hline $\mathrm{CL}$ & Cistationina Gama-Liase ou Gama-Cistationase \\
\hline $\mathrm{CTT}$ & Cistationina \\
\hline CYS & Cisteina \\
\hline DCV & Doença cardiovascular \\
\hline DP & Desvio Padrão \\
\hline EDTA & Ácido etileno diamino tetracético \\
\hline Gly & Glicina \\
\hline Hcy & Homocsiteina \\
\hline HDL & Lipoproteina de alta densidade \\
\hline HPLC & Cromatografia liquida de alta pressão \\
\hline HSD & Honest Significant Difference \\
\hline LDL & Lipoproteina de baixa densidade \\
\hline MAT & Metionina Adenosiltransferase \\
\hline MET & Metionina \\
\hline 5-metilTHF & $\mathrm{N}^{5}$-metilenotetrahidrofolato \\
\hline 5,10- metilenoTHF & $\mathrm{N}^{5,10}$ - metilenotetrahidrofolato \\
\hline MS & Metionina Sintetase \\
\hline MTHFR & $\mathrm{N}^{5,10}$ - metilenotetrahidrofolato redutase \\
\hline
\end{tabular}


PAN

PBS

R

RDA

TCEP

tHcy

TG

SAM

SAH

SBD-F

SEM

U

VLDL
Programa de Apoio a nutrição

Phosphate -buffered saline

Rural

Daily Recomended Allowence

tris 2 - carboxyethylphosphine

Homocisteina total

Triglicérideos

S-adenosilmetionina

S-adenosilhomocisteina

ammonium 7 - fluorobenzo-2-oxa-1.3 diazole - 4 -

Sulfonato

Erro do Desvio Padrão

Urbano

Lipoproteína de muita baixa densidade 


\section{ÍNDICE}

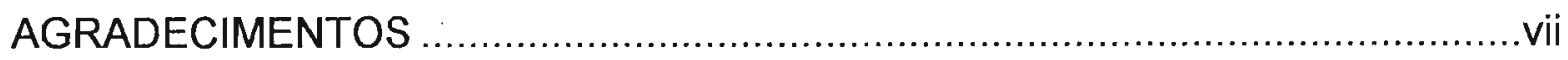

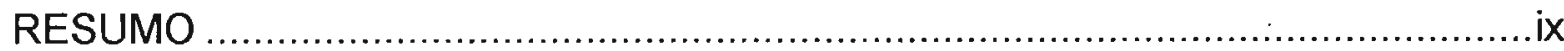

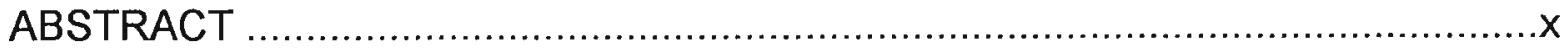

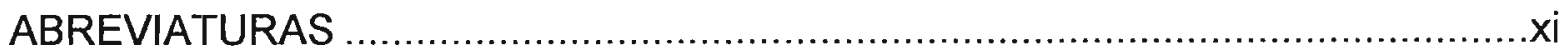

1. INTRODUÇÃO

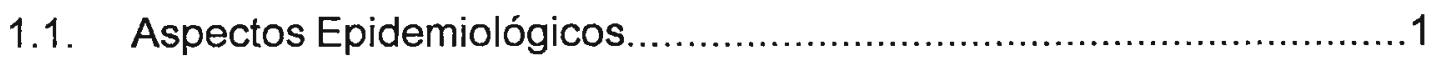

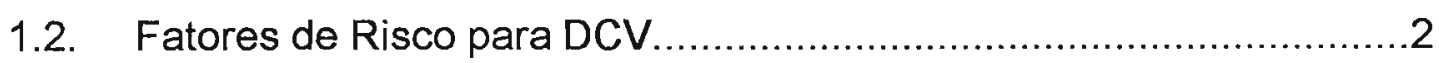

1.3. Hiperhomocisteinêmia ...............................................................

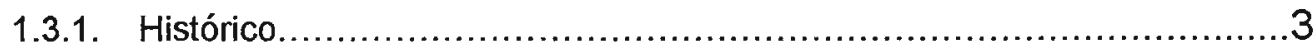

1.3.2. Metabolismo de Homocisteina e Sua Regulação.............................6

1.3.3. Anormalidades do Metabolismo de Homocisteina .........................12

1.3.3.1. Fatores Genéticos que Determinam as Anormalidades no Metabolismo de Hcy..................................................13

1.3.3.1.1. Alterações na via de Transulfuração ....................13

1.3.3.1.2. Alterações na via de Remetilação .......................14

1.3.3.2 Fatores Nutricionais que Determinam as Anormalidades no Metabolismo de Hcy ............................................16

1.3.3.2. Outros Fatores que Determinam as Anormalidades no Metabolismo de Hcy: Idade, Sexo, Estilo de Vida e Outros ......18

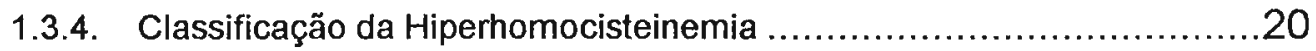

1.3.5. Determinação da Homocisteina no Plasma ou Soro .........................21

1.3.6. Mecanismos Fisiopatológicos Implicados na Hiperhomocisteinemia .....24

1.3.6.1 Alterações da Tromboresistência Vascular .........................24

1.3.6.2. Estresse Oxidativo Mediado pela Hiperhomocisteinemia ........29

1.3.6.3. Papel Alternativo de Hipometilação ....................................33

1.3.7. Tratamento Vitamínico da Hiperhomocisteinemia ..............................35

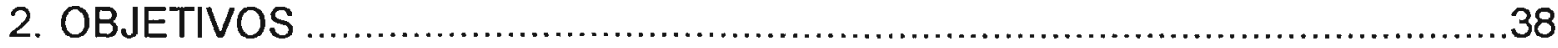

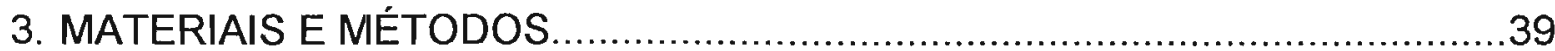

3.1. Seleção de Voluntários para Pesquisa ..........................................39

3.2. Metodologia para Estimar Consumo Diário das Vitaminas...............40

3.2.1. Inquérito Alimentar ..................................................40

3.2.1.1. O Inquérito Alimentar e Sua Aplicação ..............................40 
3.3. Metodologia para Medir Níveis Plasmáticos das Vitaminas 43

3.3.1. Dosagem de Vitamina $B_{12}$ .43

3.3.2. Dosagem de Vitamina $\mathrm{B}_{6}$ e Ácido Fólico. .44

3.4. Determinação da Concentração da Homocisteina Plasmática........47

3.4.1. Obtenção da Amostra .....................................................49

3.4.2. Técnica da Dosagem da Homocisteina .......................................50

3.5. Metodologia para Avaliar Níveis Plasmáticos dos Lipídios ................53

3.5.1. Dosagem de Trigliceridios ............................................53

3.5.2. Dosagem de Colesterol Total .............................................54

3.5.3. Dosagem de HDL Colesterol ........................................... 55

3.5.4. Cálculos da concentração de VLDL e LDL .............................. 55

3.6. Tratamento Estatístico dos Resultados ..........................................55

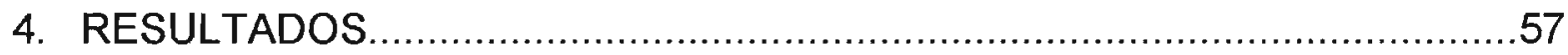

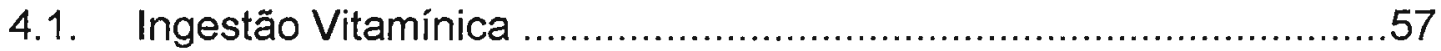

4.2. Parâmetros Plasmáticos e Séricos .......................................58

4.3. Correlação Entre a Ingestão e os Níveis Plasmáticos das Vitaminas

4.4. Correlações Entre Os Níveis Vitaminas, Hcy e Lipídios

4.5. Distribuição dos Fatores de Risco Entre as Duas Sub-populações estudadas

5. DISCUSSÃO.

5.1. Risco de Doença Cardiovascular e a Influência de Metabolismo de Homocisteína..............................................70

5.2. LDL-Colesterol, Homocisteína e a Doença Cardiovascular............84

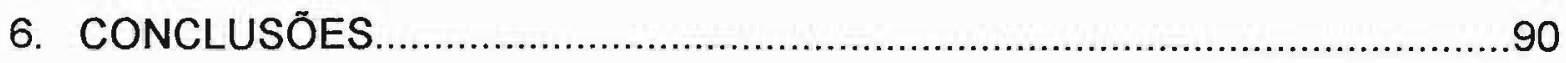

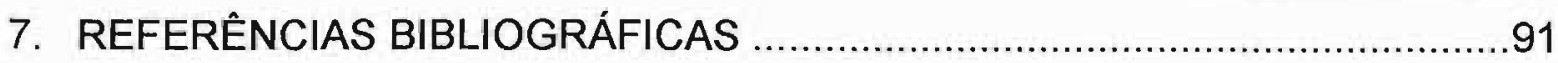

8. ANEXOS 


\section{INTRODUÇÃO}

\subsection{ASPECTOS EPIDEMIOLÓGICOS}

"Quando medito acerca de uma doença, nunca penso em termos de encontrar um remédio para ela e sim, numa forma de preveni-la" LOUIS PASTEUR, 1884 (PASTEUR,1968)

Apesar dos progressos, a doença cardiovascular é, ainda o mais sério risco à vida e à saúde. Estima-se que um em cada três homens nos Estados Unidos desenvolva algum tipo de doença cardiovascular antes de atingir 60 anos; para as mulheres as probabilidades são de uma em 10. A cardiopatia coronária é a principal causa de morte após os 40 anos entre o sexo masculino e após os 50, entre o sexo feminino (WILLIAM b. KANNEL, M.D. e THOMAS J. THOM, B.A. 1990).

Desde a década de 40, o Brasil vem passando por um processo de inversão das curvas de mortalidade, em que se observa um declínio na mortalidade por doenças infecciosas e um concomitante aumento na mortalidade por doenças crônicas não transmissiveis e causas externas. Esse processo, chamado "fenômeno de transição epidemiológica", ocorreu em todos os países hoje desenvolvidos, onde a população de idosos é cada vez mais expressiva (muw.saude.gov.br).

Em 1930, as doenças cardiovasculares (DCV) eram responsáveis por apenas $11,8 \%$ das mortes nas capitais do país. Em 1996, este percentual era de $27,4 \%$. A alta prevalência das doenças cardiovasculares é hoje observada mundialmente. No Brasil, este grupo de doenças é a principal causa de óbito: foram responsáveis, em 1996, por 249.613 óbitos dos 908.882 óbitos registrados, representado $28 \%$ do total (www.saude.gov. br). 
Mesmo quando não matam, essas doenças levam, com freqüência, à invalidez parcial ou total do indivíduo, com graves repercussões para este, sua familia e a sociedade. Isso mostra que o investimento na prevenção destas doenças é decisivo, não só para garantir qualidade de vida, mas também, para evitar gastos com hospitalização, que a cada dia se torna mais cara em razão do alto grau de sofisticação em que se encontra a medicina moderna.

\subsection{FATORES DE RISCO PARA DCV}

Não há uma causa única para as DCV mas, sabe-se que existem fatores que aumentam a probabilidade de sua ocorrência. São denominados fatores de risco cardiovascular. Estes fatores de riscos são condições ou hábitos que agridem o coração ou as artérias. Os principais são: hipertensão arterial, dislipidemia, tabagismo, diabetes mellitus, sedentarismo, obesidade e estresse.(www.saude.gov.br).

A hipertensão arterial é, dentre os fatores de risco cardiovascular, o mais importante, afetando de 11 a $20 \%$ da população adulta. A relação entre os niveis elevados de colesterol no sangue e a presença de cardiopatia coronária já está bem definida. Vários estudos mostraram que a redução dos niveis de colesterol no sangue reduz o risco de infarto agudo do miocárdio e a mortalidade por doenças cardiovasculares. (www.saude.gov.br).

Entretanto, o risco de mortalidade decorrente das DCV não é totalmente explicado pelos fatores de riscos tradicionais. Cerca de 60 a $70 \%$ dos casos de DCV estão relacionados com os principais fatores de risco, mas o restante é atribuído a outros fatores não muito evidentes. Desde a última década, a hiperhomocisteinemia tem sido apontada como um fator de risco independente 
para DCV (MOLINOW, 1990; 1994; MOLINOW e cols., 1990; WILLIAMS e cols., 1990; GENEST e cols., 1990; CLARKE e cols., 1991; GENEST e cols., 1991; TAYLOR e cols., 1991; UBBINK e cols. 1991; MOLGAARD e cols., 1992; STAMPFER e cols., 1992; ALFTHAN e cols., 1994; VERHOEF e cols., 1994; 1995; von ECKARDSTEIN e cols., 1994; ARNESEN e cols., 1995; DEN HEIJAR e cols., 1995; FORTIN \& GENEST, 1995; FUSTER, 1995; GLUECK e cols., 1995; PERRY e cols., 1995; SELHUB e cols., 1995; BERG \& BOERS, 1996).

\subsection{HIPERHOMOCISTEINEMIA}

\subsubsection{Histórico}

O aminoácido homocisteína (Hcy) foi primeiramente descrito por BUTZ \& DU VIGNEAUD em 1932. No ano seguinte, pesquisadores do Massachusetts General Hospital publicaram no New England Jornal of Medicine o relato de um caso referente a um menino de 8 anos, com homocistinúria, o qual foi a óbito após infarto cerebral decorrente de aterotrombose da artéria carótida. Acredita-se que este seja o primeiro caso descrito de homocistinúria. Trinta anos depois duas sobrinhas e um irmão do mesmo menino manifestaram homocistinúria, decorrente de um erro metabólico hereditário raro (McCULLY, 1969).

Casos de homocistinúria em crianças com retardamento mental foram descritos por GERRITSEN e cols (1962). Posteriormente, MUDD e cols. (1985 e 1995) demonstraram que o erro metabólico hereditário era decorrente da deficiência da cistationina $\beta$-sintetase. Essa descoberta abriu caminho para o reconhecimento da deficiência de outras enzimas do metabolismo da homocisteina, tais como a metionina sintetase e a metilenotetrahidofolato 
redutase, que também determinam homocistinúria. Observações clínicas em pacientes com homocistinúria alertaram quanto ao provável papel da Hcy como agente patogênico das DCV. Neste caso, os pacientes com homocistinúria apresentam alta incidência de problemas cardiovasculares na infância e adolescência, com lesões vasculares que ocorrem independentemente do defeito metabólico, sugerindo que a Hcy é a responsável pela DCV e não o defeito genético em si (SCHIMKE e cols, 1965; McCULLY, 1983; McCULLY, 1997).

A relação entre os níveis plasmáticos de homocisteína e a aterosclerose foi enfatizada por McCULLY (1969) que concluiu que o aumento de Hcy constitui um fator de risco para DCV. Ele salientou, também, que esse risco não está limitado a um pequeno número de crianças com retardamento mental, mas que um número elevado de americanos normocolesterolêmicos estariam sofrendo de DCV decorrente de níveis elevados de Hcy e, ainda, que a cura poderia estar no aumento do consumo de vitaminas do complexo B.

$\mathrm{Na}$ época, McCully estava caminhando em sentido contrário ao conceito médico, que tinha o colesterol como causa essencial das DCV, sendo por isso demitido da Universidade de Harvard, onde trabalhava como professor de patologia (MCCULLY, 1997).

CHALLEM (1997) relata que um especialista da área de colesterol, quando entrevistado pela Time em 1979, proferiu o seguinte comentário sobre a teoria da Hcy como fator de risco de DCV: "Administração de vitaminas do complexo B [para arterioesclerose é]. loucura".

Após sua demissão, McCully continuou trabalhando com Hcy e vitaminas do complexo B no Veterans Administration Hospital in Providence, R.I.(Rodh Island - USA) sendo que, nos dias de hoje, o uso de vitaminas do 
complexo B no tratamento de hiporhomocisteinemia é amplamente aceito pela medicina (CHALLEM, 1997).

O primeiro estudo clínico favorável à teoria de McCULLY foi publicado em 1976 por WILCKEN \& WILCKEN, relatando niveis elevados de Hcy em pacientes com doença coronariana, diagnosticada por angiografia. BOUSHEY e cols. (1995) analisando 27 artigos correlacionados ao metabolismo da Hcy e ácido fólico, apontam a hiperhomocisteinemia como sendo um potente fator de risco para a DCV. Atualmente, existem mais de cem estudos clínicos e epidemiológicos relacionados aos niveis de Hcy e DCV, considerando a hiperhomocisteinemia um fator independente de risco de DCV.

Por outro lado, a deficiência de ácido fólico, decorrente da mudança de hábitos alimentares da população em geral, em que os alimentos frescos, ricos em ácido fólico, estão sendo substituídos por alimentos processados ("fast food") pode ser diagnosticada através da dosagem de Hcy no plasma (CHALLEM, 1997). Neste sentido, UBBINK e cols (1993) relatam que 59\% dos homens de meia idade apresentam deficiência de acido fólico e que $30 \%$ de homens e mulheres idosas apresentam niveis elevados de Hcy, bem como que, cerca de 30 a $40 \%$ dos indivíduos com DCV apresentam níveis elevados de Hcy (SELHUB, 1993). Estes dados deixam clara a dimensão epidêmica das DCV, as quais respondem por cerca de $50 \%$ das mortes nos EUA, tendo como causa, em grande parte, um consumo inadequado de vitaminas. Neste sentido, estudando o metabolismo do ácido fólico, FROSST e cols., (1995) bem como MOLLOY e cols., (1997) verificaram a influência dos níveis desta vitamina em indivíduos com erro genético do metabolismo da Hcy, e concluindo que, níveis elevados de ácido fólico compensariam o erro genético do metabolismo da Hcy. Considerando que o 
erro genético muitas vezes passa desapercebido, CHALLEM (1997) propõe, como solução prática e barata, o consumo adequado de ácido fólico, que, neste caso, envolve um custo menor do que qualquer teste genético.

\subsubsection{Metabolismo de Homocisteina e sua Regulação}

A Hcy é um aminoácido sulfatado, que não faz parte das proteínas da dieta humana, tendo origem exclusiva como produto intermediário do metabolismo do aminoácido metionina. A metionina é único aminoácido essencial contendo sulfato, sendo encontrado em abundância em proteínas de origem animal.

Em condições normais, os mecanismos de interconversão entre metionina e homocisteína compartilham os mesmos mecanismos regulatórios, com funções metabólicas em comum (FINKELSTEIN, 2000).

Dentre os destinos metabólicos da metionina, a biossíntese de proteínas, de cisteína (aminoácido não essencial) e de S-adenosilmetionina (SAM) são de particular importância. A SAM é formada pela ação da enzima metionina adenosiltransferase (MAT) sendo fonte de grupo metila para vários aceptores em reações de grande importância fisiológica como a produção de creatina, de epinefrina, de melatonina, de nucleotídios metilados e na metilação de fosfolipídios (figura 1,reação 2) (MARKS e cols., 1996; FOWLER, 1997; MATO e cols., 1997). Essas reações são catalisadas por metiltransferases que demetilam a SAM à S-adenosilhomocisteina (SAH) que é subseqüentemente hidrolisada pela ação da adenosilhomocisteinase ou S-adenosilhomocisteína hidrolase, à Hcy e adenosina. 
Uma vez formada, a Hcy pode ser transformada em metionina pelo processo de remetilação ou degradada a cisteína pelo processo de transsulfuração (FRANKELSTEIN, 1990; FRANKELSTEIN e MARTIN, 2000). A remetilação é catalisada pela metionina sintetase (MS) (figura-1, reação 7) utilizando $\mathrm{N}^{5}$-metilenotetrahidrofolato (5-metilTHF) como doador de grupo metil e cobalamina (vitamina $\mathrm{B}_{12}$ ) como cofator. A formação de 5-metilTHF depende da enzima $\mathrm{N}^{5,10}$-metilenotetrahidrofolato redutase (MTHFR) (figura-1, reação 10) que catalisa a reduçãó de $\mathrm{N}^{5,10}$-metilenotetrahidrofolato $(5,10$-metileno THF) obtido apartir de THF.

Este ciclo básico do metabolismo da metionina ocorre em todas as células dos mamíferos. Uma pequena parte da Hcy pode ser remetilada a metionina, independente de folato e cobalamina, mas utilizando, entretanto, a betaína (derivado da colina) pela ação da enzima betaína-homocisteína metiltransferase (BHMT)(figura-1 reação 8) a qual, provavelmente, está confinada ao fígado. Na deficiência de folato e/ou cobalamina, este mecanismo mantém a concentração tecidual da metionina necessária para síntese de SAM (MCKEEVER e cols., 1991; SUNDEN, 1997).

A via de transsulfuração remove a Hcy do ciclo da metionina de forma irreversível, convertendo a homocisteína em cisteína e $\alpha$-cetobutirato. $\mathrm{O}$ caminho metabólico da transsulfuração envolve as enzimas cistationina $\beta$ sintetase (CBS) e cistationina $\gamma$-liase $(C L)$ ambas dependentes de vitamina $B_{6}$ (piridoxal fosfato) como cofator. A CBS é uma hemoproteína que catalisa, primeiramente, a transformação irreversivel da Hcy em cistationina (CTT) (figura1, reação 5). Na seqüência, a cistationina resultante é convertida em cisteína (CYS) e $\alpha$-cetobutirato, em reação catalisada pela $C L$, também conhecida como 
$\gamma$-cistationase (figura-1, reação 6). A cisteína formada neste processo pode ser utilizada na síntese de proteínas e do tripeptídio antioxidante, glutationa.

Em contraste com a via de remetilação, a transsulfuração apresenta distribuição tecidual limitada, nos mamíferos. Fígado, rins, intestino delgado e pâncreas são órgãos que apresentam atividade das enzimas de transsulfuração, sendo essenciais para a retirada e metabolização do excesso de Hcy circulante (FRANKELSTEIN, 1990; BLOM, 2000). Tecidos com niveis das enzimas de transsulfuração abaixo do limite de detecção necessitam de cisteína exógena para síntese de glutationa (FRANKELSTEIN e MARTIN, 2000).

A distribuição de substratos entre os processos de transmetilação e remetilação-transsulfuração regulam o metabolismo de Hcy e da metionina nos tecidos humanos. A via de transmetilação corresponde à utilização da metionina no processo de biossíntese de proteínas e de SAM. Por outro lado, o processo de remetilação-transsulfuração compartilha a utilização da Hcy celular, a qual é sintetizada por transmetilação, ocorrendo, desta forma, competição pelo substrato Hcy entre as duas vias. Neste sentido, cabe lembrar que o controle dessas vias metabólicas envolve a competição pelo substrato Hcy, bem como o efeito modulador da SAM sobre enzimas importantes dos sistemas de transmetilação e remetilação-transsulfuração (FRANKELSTEIN , 2000).

SAM regula, simultaneamente, a remetilação e a degradação da Hcy, inibindo as enzimas conversoras de metionina que apresentam $K_{M}$ baixo, ativando as enzimas catabolisadoras de metionina que apresentam $K_{M}$ elevado (FRANKELSTEIN, 1990; SELHUB \& MILLER, 1992 ). Desta forma, quando os 


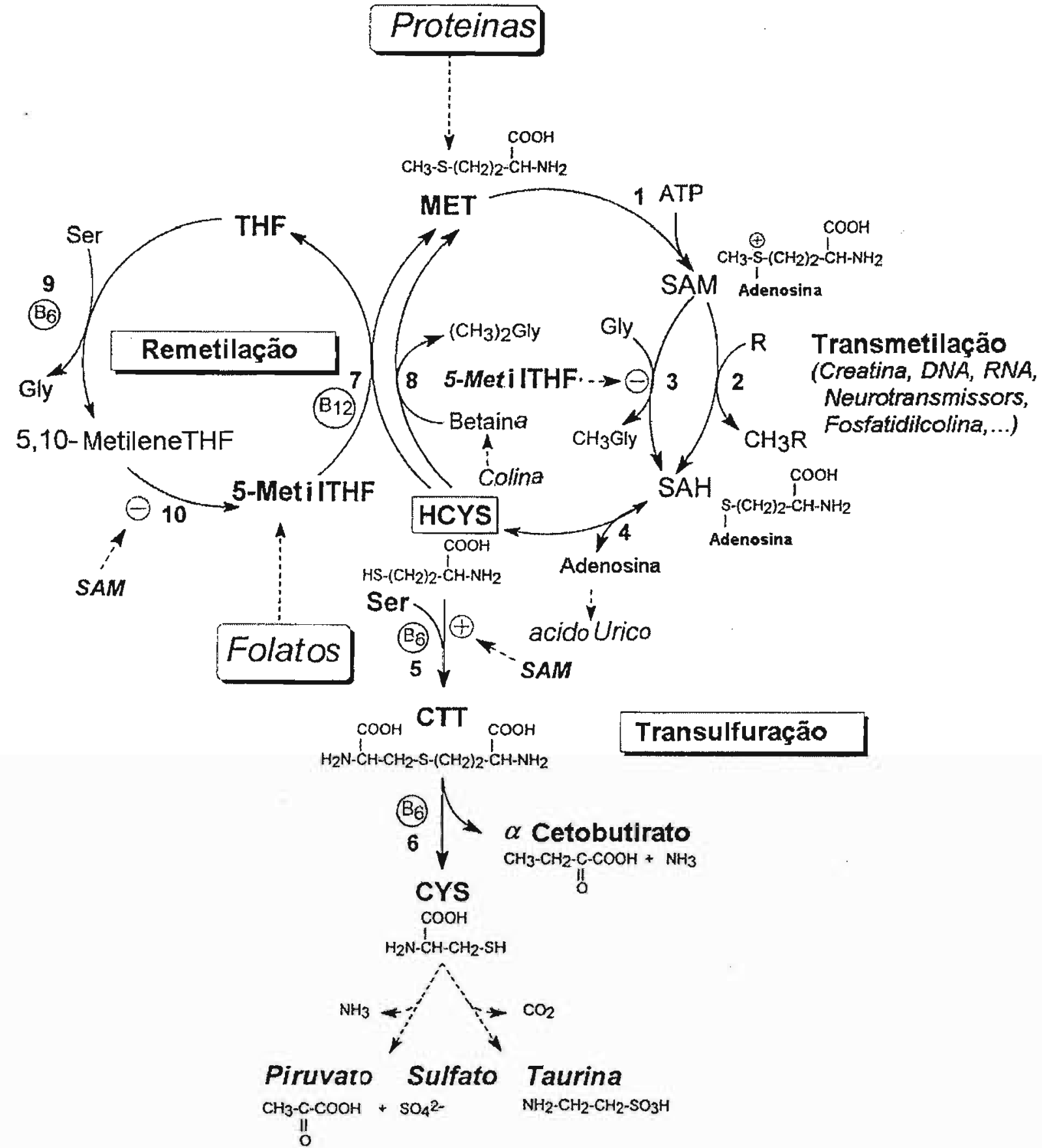

Figura - 1. Metabolismo de Homocisteina

(1) Ativação da metionina (MET) pelo ATP, na presença da enzima metionina adenosil transferase (MAT)

(2) S-adenosilmetionina (SAM) desmetilada em S-adenosilhomocisteína (SAH) acoplada à metilação do aceptor $\mathrm{R}$ a $\mathrm{RCH}_{3}$.

(3) Desmetilação alternativa catalisada por glicina N-metiltransferase, que converte glicina (Gly) em sarcosina $\left(\mathrm{CH}_{3} \mathrm{Gly}\right)$.

(4) Hidrólise da SAH em homocisteina (Hcy) e adenosina, catalisada por S-adenosilhomocisteína hidrolase.

(5) Condensação da serina (Ser) com a Hcy para formar cistationina (CTT) pela ação da enzima cistationina beta sintetase (CBS), que é dependente da vitamina $B_{6}$, na forma de piridoxina -5 '-fosfato.

(6) Conversão da CTT em CYS e alfa-cetobutirato, catalizada pela cistationase (CL), que é dependente da vitamina $B_{6}$, na forma de piridoxina-5'-fosfato.

(7) N-metil tetrahidrofolato (5-metilTHF) é desmetilado a THF e a Hcy é remetilada a MET pela metionina sintetase (MS), que é dependente da vitamina $B_{12}$ derivada da metilcobalamina.

(8) Remetilação da Hcy pela enzima betaína-homocisteína metiltransferase no fígado, na presença da betaina, derivada da colina.

(9) Sintese de N 5-10-metilenoTHF apartir de THF, acoplado à conversão da Ser a Gly pela ação da enzima serina hidroximetil transferase, que é dependente da vitamina $B_{6}$, na forma de piridoxina -5'-fosfato.

(10) Redução do 5,10, metilenoTHF em 5-metilTHF catalizada pela enzima N,5-10-metilenotetrahidorfolato redutase (MTHFR). 
niveis de SAM são suficientes para manter as reações de transmetilação, este reduz a taxa de remetilação da Hcy, inibindo a atividade da metilenotetrahidrofolato redutase (figura-1, reação 10) ( FOWLER,1997).

SAM também regula a remetilação hepática da Hcy, limitando tanto a atividade como a síntese da BHMT (figura-1, reação 8), inibindo as enzimas com $\mathrm{K}_{\mathrm{M}}$ menor, como a MAT tipo I (hepática) e a MAT tipo II presente em tecidos extrahepáticos (figura-1, reação 1). Ao contrário, a SAM estimula a MAT III de $\mathrm{K}_{M}$ elevado, presente no tecido hepático, além de estimular a via alternativa de transmetilação, ativando a glicina transmetilase (figura-1, reação 3) (FRANKELSTEIN, 1990).

Adicionalmente, para evitar o acúmulo de Hcy, que é potencialmente citotóxica, a SAM estimula a transsulfuração, ativando as enzimas CBS e CL (FRANKELSTEIN, 1990; FOWLER,1997). Considerando que as concentrações de SAM variam dentro de uma faixa muito restrita em todos os tecidos exceto tecido hepático, é provável que as propriedades regulátórias de SAM sejam mais siginficantes nos tecidos extrahepáticos (FRANKELSTEIN, 2000).

Dietas ricas em proteínas animais são ricas em metionina e podem levar a um aumento das concentrações celulares de SAM. Nestas condições, $70 \%$ de Hcy é catabolisada pela CBS via transsulfuração (figura-1). Em contraste, sob condições de restrição protéica, a remetilação é favorecida pela aceleração da metilenotetrahidrofolato redutase dependente do folato (figura-1,reação 10). Neste caso, somente $10 \%$ da Hcy é catabolisada via transsulfuração (DURAND e cols. 2001)

Todavia, o consumo de altos níveis de metionina a longo prazo pode levar à saturação da via de transsulfuração. Esta saturação, associada à inibição 
da remetilação, leva ao acúmulo de Hcy celular e, consequentemente, extravasamento desta para corrente sangüínea. Estudos como o de UELAND \& REFSUM (1989) mostram que dietas ricas em metionina, ou uma grande sobrecarga de metionina, levam à saída de Hcy das células, resultando em aumento plasmático dos niveis de Hcy.

O "pool" intracelular de folatos também está envolvido na regulação do metabolismo da Hcy por fornecer 5-metilTHF. Este último é necessário na remetilação da Hcy à metionina. Logo, 5-metilTHF mantém níveis adequados de SAM para os tecidos quando há restrição exógena da doação do grupo metil pela metionina e pela colina. Em condições de consumo de altos níveis de folato, o 5metilTHF inibe a via alternativa de transmetilação, inativando a glicina metiltransferase (figura-1, reação 3) resultando em aumento tecidual nos níveis de SAM. Este aumento de SAM limita a mobilização intracelular do "pool" de folato na via remetilação da Hcy (figura-1, reação 10) (DURAND e cols., 1997a).

Em contrapartida, um decréscimo na biodisponibilidade de 5metilTHF gera uma redução de remetilação da Hcy (figura-1, reação 7) e a aceleração da via alternativa de transmetilação (figura-1, reação 3). Uma diminuição nos níveis de SAM, por depleção dos estoques de folato, induz inibição das reações da transsulfuração (figura-1, reação 5) (DURAND e cols., 1997a). Deficiências nutricionais de folato e uso de drogas que interferem com o metabolismo de folato, como metatrexato, agentes anticarcinogênicos que inibem a THFredutase e dióxido nitroso, um gás anestésico que inibe a atividade da MS, levam ao acúmulo e efluxo celular de Hcy, aumentando os níveis circulatórios de Hcy (UELAND \& REFSUM, 1989). 
Estudos como os de CHEN \& BANERJEE (1998) e TAOKA e cols. (1998) revelaram a sensibilidade oxidativa da MS e CBS e sugeriram uma regulação redox das vias de remetilação e transulfuração. A CBS, uma hemeproteína, é ativa na forma oxidada, enquanto que a MS é inativada com a oxidação e requer uma redução para sua reativação. De acordo com este mecanismo de regulação, o qual deve ter significado fisiológico, o metabolismo de Hcy é desviado para a produção da CYS e da glutationa, via transsulfuração, em células hepáticas expostas a condições oxidativas (MOSHAROV e cols., 2000). Logo, é possivel que o estresse oxidativo reduza a remetilação e aumente a transsulfuração para manter um processo de autocorreção e manter o "pool" intracelular de glutationa, essencial para a capacidade regulatória redox da célula.

\subsubsection{Anormalidades do Metabolismo de Homocisteína}

Disfunções relacionadas aos defeitos congênitos nas enzimas envolvidas no metabolismo de Hcy, deficiências no fornecimento, absorção ou metabolismo das vitaminas ácido fólico, $B_{6}$ e $B_{12}$, e consumo excessivo de metionina, todos são fatores que contribuem para o aumento dos níveis plasmáticos de Hcy (Tabela-1 do DURAND e cols., 2001). É interessante notar que interações gene-nutriente, especialmente entre a mutação C677T no gene da MTHFR e níveis de folato e também, entre a heterogeneidade para o defeito da CBS e folato, podem estar envolvidos no início da hiperhomocisteinemia (LENTZ e cols., 2000)

Outro ponto a verificar é o aumento do transporte da Hcy dos tecidos para o plasma, que é regulado pelo carreador de Hcy na forma reduzida (BLOM, 2000). A hiperhomocisteinemia também pode ser resultante da redução 
da função renal, o qual tem papel central na depuração da Hcy plasmática, risco da insuficiência crônica hepática.

\subsubsection{Fatores Genéticos que Determinam as Anormalidades no Metabolsimo de Hcy}

\subsection{Alterações na Via de Transsulfuração}

Uma das alterações clássicas do metabolismo da Hcy é a deficiência do homozigoto da cistationina $\beta$ sintetase (CBS) (MUDD e cols., 1995). Este defeito autossômico recessivo resulta em homocistinúria, associada a niveis anormalmente altos de Hcy e metionina plasmática. Os individuos com esta patologia representam uma fração pequena da população, aproximadamente 1 em 200.000 indivíduos no mundo. Estes indivíduos apresentam hiperhomocisteinemia muito severa, com níveis plasmáticos de Hcy atingindo a $400 \mu \mathrm{mol} / \mathrm{L}$.

Em pacientes com atividade da CBS entre $0-2 \%$, que são quase metade dos casos da homocistinúria homozigota, o tratamento com vitamina $\mathrm{B}_{6}$ pode reduzir a hiperhomocisteinemia. Tratamento com folato tem efeito nos pacientes que não respondem à vitamina $B_{6}$ (FRANKEN e cols., 1994). Trinta e três mutações pontuais foram identificadas no gene da CBS, que se localiza no cromossomo 21. Entre as mutações, a G919A, onde a base nitrogenada guanina foi trocada por adenina na posição 919, é freqüentemente encontrada na população irlandesa, enquanto a mutação T833C é freqüente observada na população alemã (LENTZ e cols., 2000).

A freqüência de indivíduos heterozigotas para CBS é de 1/70 a 1/200 na população em geral. 30 a 50\% dos casos apresentam Hcy plasmática 
normal. O aumento de Hcy nestes indivíduos pode ser atenuado pela suplementação com ácido fólico. O trabalho de LENTZ e cols. (2000) utilizando camundongos trangênicos, sugere que a deficiência de ácido fólico predispõe indivíduos heterozigotos para CBS a apresentarem hiperhomocisteinemia. A deficiência de CBS é o erro mais comum na hiperhomocisteinemia (MUDD \& LEVY, 1995). É interessante ressaltar que pacientes com síndrome de Down, que possuem uma cópia adicional do gene da CBS, geralmente apresentam níveis baixos de Hcy, sendo esta condição considerada um "modelo livre de ateromatose" (SCOTT, 1996; MURDOCH e cols., 1977).

\subsection{Alterações na Via de Remetilação}

A hiperhomocisteinemia resultante de alterações da via de remetilação é rara. Ainda assim, atividade de MTHFR menor que $20 \%$ ou deficiência funcional da MS levam ambas à hiperhomocisteinemia severa. Nove mutações termoestáveis para o gene de MTHFR, localizado no cromossomo 1, de herança autossômica recessiva, devem ser responsáveis pela redução da atividade da enzima. Mutações do tipo C599T e G482A são os dois tipos principais e a hiperhomocisteinemia é observada somente em indivíduos homozigotos. Apesar da hiperhomocisteinemia destes pacientes ser menos severa que na deficiência homozigota da CBS, nenhum tratamento com vitaminas foi realmente efetivo, apesar de ser observada uma redução na hiperhomocisteinemia usando ácido fólico ou 5-metilTHF (FENTON \& ROSENBERG, 1995; ROSENBLATT, 1995). 
Tabela - 1: Causas de Hiperhomocisteinemia

\begin{tabular}{|c|c|}
\hline FATORES GENÉTICOS & RELAÇĀO \\
\hline $\begin{array}{l}\text { Defeito da MTHFR } \\
\text { (atividade }<20 \% \text { ) }\end{array}$ & $\begin{array}{l}\text { Mutação homozigoto termoestável (raro) } \\
\text { Hiperhomocisteinemia severa em Jejum }\end{array}$ \\
\hline $\begin{array}{l}\text { Defeito da MTHFR } \\
\text { (atividade }<50 \% \text { ) }\end{array}$ & $\begin{array}{l}\text { Mutação homozigoto termolabil C677T } \\
\text { Hiperhomocisteinemia Moderada }\end{array}$ \\
\hline $\begin{array}{l}\text { Defeito da CBS } \\
\text { (atividade }<2 \% \text { ) }\end{array}$ & $\begin{array}{l}\text { Homozigoto (raro) } \\
\text { Hiprehomocisteinemia severa }\end{array}$ \\
\hline Deficiência da CBS & $\begin{array}{l}\text { Heterozigoto (0.5-1.5\%), aumento de Hcy } \\
\text { após sobrecarga da metionina }\end{array}$ \\
\hline $\begin{array}{l}\text { Deficiência funcional da } \\
\text { metionina sintetase }\end{array}$ & $\begin{array}{l}\text { Mutação rara, hiperhomocisteinemia } \\
\text { intermediária a severa }\end{array}$ \\
\hline $\begin{array}{c}\text { FATORES } \\
\text { FISIOLÓGICOS } \\
\end{array}$ & RELAÇÃO \\
\hline Idade & $\begin{array}{l}\text { Os níveis plasmaticos de Hcy aumentam } \\
\text { com idade }\end{array}$ \\
\hline Sexo & $\begin{array}{l}\text { Os homens apresentam niveis maiores de } \\
\text { Hcy que mulheres }\end{array}$ \\
\hline Menopausa & $\begin{array}{l}\text { Aumento de niveis plasmáticos de Hcy após } \\
\text { menopausa }\end{array}$ \\
\hline Raça & $\begin{array}{l}\text { Níveis Hcy são menores nos negros que } \\
\text { nos brancos }\end{array}$ \\
\hline $\begin{array}{c}\text { FATORES } \\
\text { NUTRICIONAIS } \\
\end{array}$ & RELAÇÃO \\
\hline $\begin{array}{l}\text { Deficiência de vitamina } \\
\mathrm{B}_{6}\end{array}$ & $\begin{array}{l}\text { Aumento de Hcy após sobrecarga da } \\
\text { metionina }\end{array}$ \\
\hline $\begin{array}{l}\text { Deficiência de vitamina } \\
\mathrm{B}_{12}\end{array}$ & $\begin{array}{l}\text { Hiperhomocisteinemia moderada a } \\
\text { intermediária }\end{array}$ \\
\hline $\begin{array}{l}\text { Deficiência do ácido } \\
\text { fólico }\end{array}$ & $\begin{array}{l}\text { Hiperhomocisteinemia moderada a } \\
\text { intermediária }\end{array}$ \\
\hline $\begin{array}{l}\text { Excesso proteína animal } \\
\text { rico em metionina }\end{array}$ & $\begin{array}{l}\text { Hiperhomocisteinemia moderada a } \\
\text { intermediária e aumento de Hcy após } \\
\text { sobrecarga da metionina }\end{array}$ \\
\hline $\begin{array}{c}\text { FATORES } \\
\text { PATOLÓGICOS }\end{array}$ & RELAÇÄO \\
\hline Fumo & $\begin{array}{l}\text { Alteração do metabolismo de ácido fólico e } \\
\text { deficiência de vitamina } B_{6}\end{array}$ \\
\hline Alcoolismo & Metabolismo de ácido fólico alterado \\
\hline Função renal alterada & Redução de depuração da Hcy \\
\hline Psoriasis & Alteração do uso intracelular da Hcy \\
\hline Câncer & Alteração do uso intracelular da Hcy \\
\hline $\begin{array}{l}\text { FATORES } \\
\text { IATROGENICO }\end{array}$ & RELAÇÄO \\
\hline Anticoncepcionais & Metabolismo alterado de ácido fólico \\
\hline Metatrexato & Inibição da dihidrofolato redutase \\
\hline Óxido nitroso & Inibição da Metionina sintetase \\
\hline Anticonvulsivos & Metabolismo alterado de ácido fólico \\
\hline
\end{tabular}


A mutação do tipo C677T do gene MTHFR, a qual leva à síntese de uma MTHFR termolábil, é responsável por $50 \%$ da atividade da enzima nos individuos homozigotos. Esta mutação aparece com frequência de 30 a $40 \%$ na população, de acordo com a distribuição geográfica (D'ANGELO E SELHUB, 1997; FRANCO e cols., 1998). Nos indivíduos homozigotos, esta mutação autossômica recessiva provoca hiperhomocisteinemia moderada, que pode ser tratada com suplemento de ácido fólico, uma vez que o aumento nos níveis de Hcy deixa de ser observado em pacientes com concentrações plasmáticas de ácido fólico maiores que 15,4ๆmol/L (JACQUES e cols., 1996). A deficiência de ácido fólico pode ser parcialmente responsável pela expressão do genótipo da MTHFR termolábil e a hiperhomocisteinemia observada nestes pacientes com mutação para MTHFR, raramente, resulta de uma maior necessidade do ácido fólico (MOLLOY e cols., 1997).

Cinco mutações conhecidas afetam a síntese de metilcobalamina, que é um cofator essencial para MS. Estas mutações induzem à deficiência funcional da MS, levando a uma hiperhomocisteinemia intermediária. A deficiência funcional da MS pode ser devida a uma mutação tanto no gene que codifica a própria enzima, como no gene que codifica a metionina sintetase redutase, enzima envolvida na ativação da MS (LECLERC e cols., 1998).

\subsubsection{Fatores Nutricionais que Determinam as Anormalidades No Metabolismo de Hcy}

Entre os vários fatores conhecidos que influenciam o metabolismo de Hcy, se destacam as vitaminas $B_{6}$ e $B_{12}$ e o ácido fólico. Como descrito anteriormente (Item 1.3.2) a Hcy é remetilada a metionina pela ação da MS, que 
necessita de metilTHF como doador de grupo metila e da vitamina $\mathrm{B}_{12}$ como cofator. A Hcy também pode seguir a via de transsulfuração, onde as reações necessitam de vitamina $\mathrm{B}_{6}$ como cofator.

Vários trabalhos, conduzidos tanto em animais como no homem, mostram que deficiências alimentares da vitamina $B_{12}$ e ácido fólico induzem hiperhomocisteinemia moderada ou intermediária, sob condições basais (DURAND e cols 1996, 1997b). Em meta-análise realizada por SELHUB e cols. (1993) no Framingham Heart Study, verifica-se que a elevação da Hcy está associada a níveis séricos baixos de ácido fólico, assim como o baixo consumo alimentar de ácido fólico e vitamina B6. PANCHARUNITI e cols. (1994) estudando 101 homens de raça branca com idade de variando entre 30 e 50 anos, concluem que níveis baixos de folato estão associados com aumento de risco de DCV e que este efeito é mediado, em grande parte, pelos concentrações plasmáticas de Hcy. JACOB e cols. (1994) estudaram a alteração dos níveis de Hcy em indivíduos sadios recebendo dieta restrita em ácido fólico ou dieta suplementada com ácido fólico, por 108 dias. Os autores concluíram que há aumento nos níveis de Hcy durante a depleção de ácido fólico e que este aumento funcionaria como marcador da deficiência desta vitamina.

Em 1995, DALERY e cols. determinaram os níveis plasmáticos de Hcy, das vitaminas $B_{6}, B_{12}$ e de ácido fólico em 584 canadenses de origem francesa, concluindo que, os níveis plasmáticos de Hcy, nestes indivíduos, são influenciados pelo níveis de ácido fólico, de vitaminas $B_{12}$ e $B_{6}$.

BROUWER e cols. (1999), APPEL e cols., (2000) e HERRMANN e cols. (2001) estudaram os efeitos da dieta contendo alimentos ricos em vitaminas, como ácido fólico, vitaminas $\mathrm{B}_{6}$ e $\mathrm{B}_{12}$, sobre os níveis de $\mathrm{Hcy}$, concluindo que, o 
aumento no consumo de verduras e frutas cítricas, fontes ricas em ácido fólico, previne a falta deste e diminui a concentração de Hcy, indicando que a dieta apresenta importância na prevenção da DCV.

As deficiências de ácido fólico e cobalamina são as causas mais comuns de hiperhomocistinemia moderada e intermediária. A incidência destas deficiências aumenta com a idade. Na maioria dos casos, a deficiência da cobalamina é resultado da má-absorção, enquanto que a deficiência do ácido fólico é mais freqüente quando do uso de dietas pobres nesta vitamina, do uso de drogas ou de álcool em excesso.

Apesar da vitamina $B_{6}$ ser necessária nas reações da via de transsulfuração, sua deficiência isoladamente é rara, sendo a suplementação com esta vitamina sem efeito no controle dos níveis de Hcy (SCHNEEDE e cols., 2000; KOEHLER e cols., 2001).

\subsubsection{Outros Fatores que Determinam as Anormalidades No Metabolismo da Hcy: Idade, Sexo, Estilo de Vida e outros}

A Hcy plasmática aumenta ao longo da vida, tanto no sexo feminino como no masculino; entretanto, concentrações maiores de Hcy são encontrados em homens, quando comparado às mulheres. Na infância, os níveis de Hcy em meninos e meninas é similar, em torno de $5 \mu \mathrm{mol} / \mathrm{L}$. Nota-se, entretanto, aumento pronunciado nos meninos durante a puberdade, onde os níveis de Hcy chegam a 6 a $7 \mu \mathrm{mol} / \mathrm{L}$ (TONSTAD e cols., 1996; BJORKE-MONSEN e cols., 1998).

Nos adultos, os níveis plasmáticos de Hcy encontrados são 1 a 2 $\mu \mathrm{mol} / \mathrm{L}$, mais altos nos homens do que nas mulheres. No estudo feito por NYGARD e cols. (1995) com 5918 homens e 6348 mulheres sadios com idade 
entre 40 a 42 anos, verificou-se uma média de 10,8 $\mu$ mol/L para homens e 9,1 $\mu \mathrm{mol} / \mathrm{L}$ para mulheres. As diferenças relacionadas ao sexo são explicadas pelo efeito dos esteróides sobre a Hcy; nos homens, há uma produção maior de Hcy que pode estar relacionada à síntese da creatina e creatinina (ANDERSSON e cols., 1992; NORLUND e cols., 1992). As diferenças também podem ser parcialmente explicadas por diferenças na transsulfuração e remetilação da Hcy, mais eficientes nas mulheres do que nos homens (SILBERBERG e cols., 1997; FUKAGAWA e cols., 2000). Contudo, após a menopausa nas mulheres, as concentrações de Hcy nos dois sexos se aproximam, sendo que a terapia da reposição hormonal atenua o aumento nos niveis plasmáticos observado após a menopausa (MIJATOVIC e cols., 1998).

Nos idosos, um grande número de indivíduos apresenta hiperhomocisteinemia. Com a idade, o aumento dos niveis de Hcy pode ser atribuído à alterações das funções renais, às deficiências nos níveis de ácido fólico e à deficiência na absorção da cobalamina. Em indivíduos com mais de 70 anos, 30\% apresentam niveis de Hcy superiores a $15 \mu \mathrm{mol} / \mathrm{L}$ (UBBINK, 1998; WILCKEN \& WILCKEN, 1998; BJORKERGERN \& SVARDSUDD, 2001).

Numerosas drogas podem levar ao quadro de hiperhomocisteinemia. Agentes anticancerígenos como metatrexato e anticonvulsivos usados na epilepsia, podem induzir hiperhomocisteinemia secundária por prejudicarem o metabolismo do ácido fólico. O óxido nitroso $\left(\mathrm{N}_{2} \mathrm{O}\right)$, gás anestésico que inibe a atividade da MS, também induz a hiperhomocisteinemia. Transplantes cardíacos e renais levam à hiperhomocisteinemia devido à deficiência de ácido fólico e vitamina $\mathrm{B}_{6}$; além disto o quadro pode ser agravado pelo uso de agentes 
imunossupressores como a ciclosporina, que interfere na depuração da Hcy plasmática (FRONTIERA e cols., 1994; BOSTOM e cols., 1997).

O estilo de vida com hábitos alimentares não sadios, o tabagismo e o consumo excessivo de álcool, podem levar à hiperhomocisteinemia, através da alteração do metabolismo de ácido fólico e depleção de vitamina $\mathrm{B}_{6}$ (CARVO e cols., 1996; NYGRD e cols., 1998). Adicionalmente, o consumo excessivo de café aumenta os ríveis de Hcy, enquanto que o de chá, de suplementos vitamínicos, verduras e frutas, assim como a atividade física, estão relacionados inversamente aos niveis de Hcy (BROUWER e cols., 1999; APPEL e cols., 2000; BROEKMANS e cols., 2000; RASMUSSEN e cols.,2000).

\subsubsection{Classificação da Hiperhomocisteinemia}

A classificação da hiperhomocisteinemia está baseado nos niveis plasmáticos de Hcy medidos em jejum (DURAND e cols.,2001).

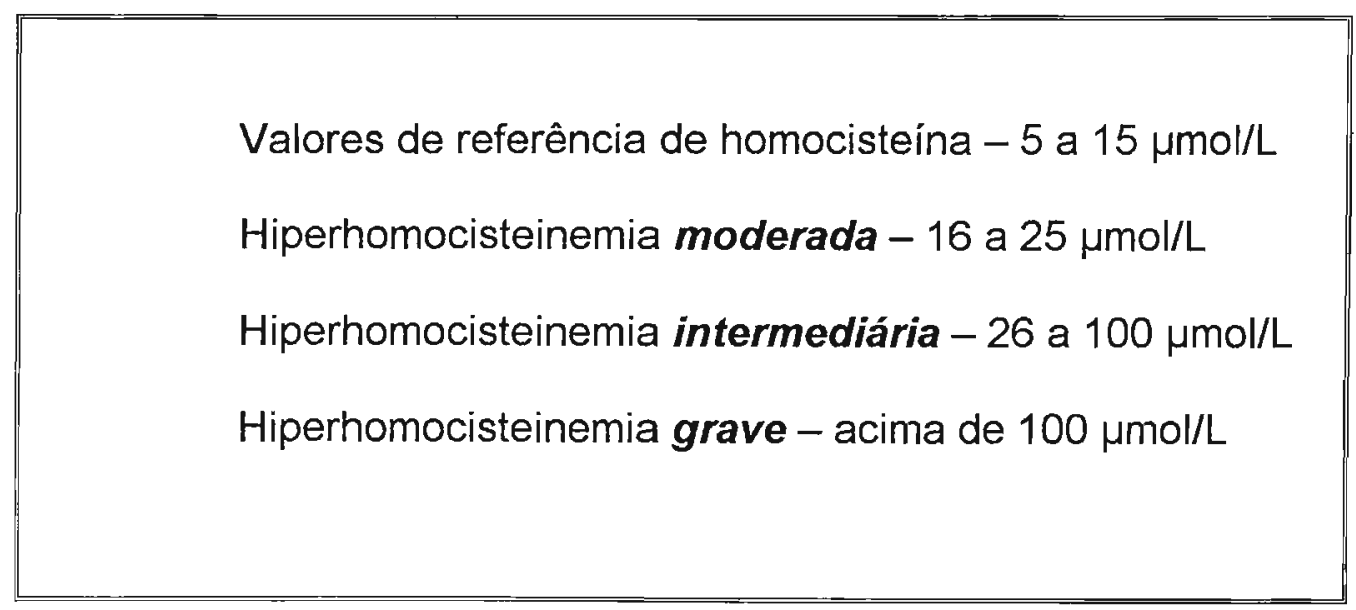

A importância da hiperhomocisteinemia moderada e de outros fatores convencionais, como sexo e idade, sobre a incidência de patologias vasculares foi estudada por GRAHAM e cols. (1997) que verificam que o nível de 
corte para hiperhomocisteína em jejum é de $12 \mu \mathrm{mol} / \mathrm{L}$. Uma declaração feita por profissionais da área da saúde (Nutrition Commitee, American Heart Association, 1999) sugere a dosagem dos níveis de Hcy plasmática em indivíduos com histórico familiar de aterosclerose prematura e concorda que os niveis de Hcy em jejum devem ser menores que $10 \mu \mathrm{mol} / \mathrm{L}$ (MALINOW e cols., 1999).

\subsubsection{Determinação da Homocisteina no Plasma ou Soro}

A concentração da Hcy no plasma ou soro em adultos é, em média, $10 \mu \mathrm{mol} / \mathrm{L}$. A Hcy existe em várias formas (figura-2). Quantidades pequenas (1\%) se encontram na forma reduzida; o restante se encontra na forma oxidada, na forma de dissulfeto (UELAND e cols., 1996). Destes, 70 a $80 \%$ estão ligados à proteína plasmática albumina (via ponte dissulfeto) enquanto o restante existe na forma dissulfeto livre, sendo maior parte na forma de dissulfeto misto Hcy-Cys (Figura - 2)

Esta interconversão de diferentes espécies de Hcy explica os problemas analíticos que foram resolvidos após a introdução do novos métodos de dosagem da tHcy nos anos 80 (UELAND e cols., 1993). Homocisteína total (tHcy) é um termo metodológico que se refere à concentração obtida do plasma ou soro submetido ao tratamento de redução para converter todas as formas, ligadas e livres, ao seus compostos sulfidrilas. O termo Hcy é usado para homocisteina e suas espécies oxidadas.

UELAND e cols. (1993) publicaram um trabalho que revisa o histórico e todos os princípios envolvidos em vários métodos de dosagem da Hcy. O princípio comum a todos os métodos de dosagem de Hcy é a utilização de um redutor para clivar todas as pontes dissulfeto entre Hcy e proteinas ou outros tióis, 
podendo ser quantificada diretamente, ou depois da derivatização. A maioria dos ensaios estão baseados na cromatografia líquida de alta eficiência (HPLC) com detecção fluorimétrica. Um ensaio totalmente automatizado, semelhante ao método de enzima-imunoensaio da Bio-Rad, é citado em DONNELLY \& PRONOVOST (2000) e YU e cols. (2000) apresentando uma correlação com os resultados obtidos pela técnica de HPLC, sendo, portanto, útil para centros de estudos populacionais.

Algumas precauções são necessárias na detecção da Hcy, como a coleta de sangue em jejum. Para evitar a liberação da Hcy por eritrócitos, a amostra deve ser mantida em gelo logo após a coleta e o plasma deve ser separado rapidamente antes de 4 horas quando a $4^{\circ} \mathrm{C}$, ou antes de uma hora, se a temperatura ambiente ( ANDERSON e cols., 1992; UELAND e cols., 1993; MALINOW e cols., 1994; NYGARD e cols., 1999).

Dados recentes de O'BROIN e cols. (2000) indicam que o ácido cítrico pode ser usado como anticoagulante, além de EDTA e heparina. CLARKE e cols. (1998) sugerem que a concentração da tHcy em um indivíduo é relativamente constante, podendo ser determinada por uma dosagem única. Quando o manuseio da amostra é padronizado, o método apresenta um coeficiente de variação analítico aceitável.

O teste de sobrecarga de metionina é utilizado para revelar anormalidades adicionais, não detectáveis pela simples dosagem da tHcy plasmática em jejum. Em indivíduos normais, é utilizada a dosagem de $100 \mathrm{mg} / \mathrm{kg}$ de peso, que induz um aumento nos níveis de Hcy até $27 \mu \mathrm{mol} / \mathrm{L} ;$ o pico aparece entre 4 a 8 horas após a sobrecarga. Este teste foi originalmente utilizado para 
<smiles>NC(CCS)C(=O)O</smiles>

Homocisteina<smiles>NC(CS)C(=O)O</smiles>

Cisteína<smiles>NC(CCSSCCC(N)C(=O)O)C(=O)O</smiles>

Homocistína<smiles>NC(CCSSCC(N)C(=O)O)C(=O)O</smiles>

Homocisteína-cisteína

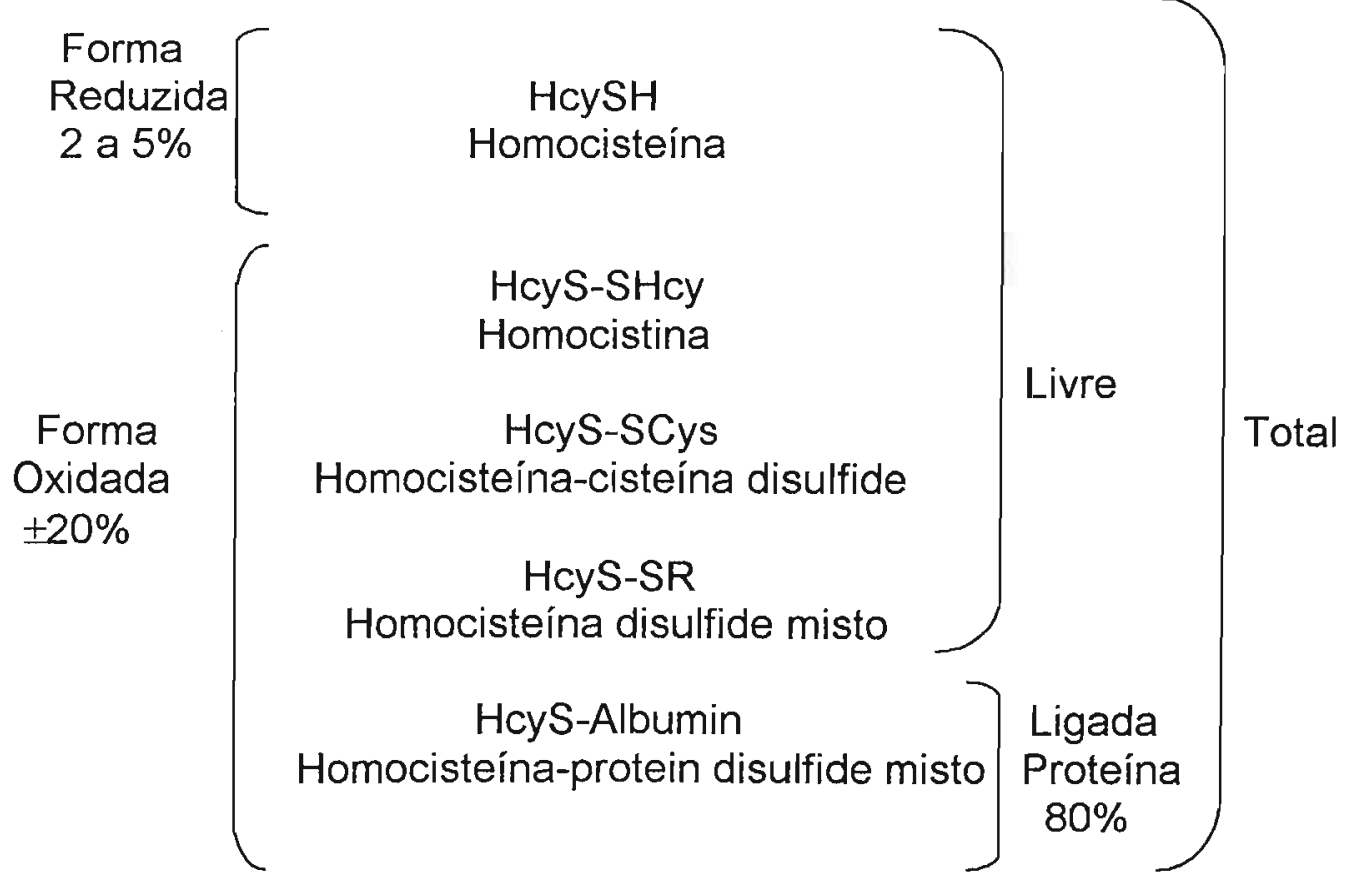

Figura-2: Formas do Homocisteina presentes no sangue 
detectar a deficiência do heterozigoto da cistationa $\beta$ sintetase (CBS) (GRAHAM e cols., 1997). Apesar do teste ser mais sensivel para a via de transsulfuração, a resposta pode ser anormal em indivíduos com defeitos na via de remetilação (CATTANEO,1999). 40\% dos indivíduos que apresentam tHcy normal em jejum mostram elevação de Hcy no teste de sobrecarga de metionina.

\subsubsection{Mecanismos Fisiopatológicos Implicados na Hiperhomocisteinemia}

Apesar da grande quantidade de trabalhos epidemiológicos, mostrando dados que indicam uma relação entre hiperhomocisteinemia e aumento de risco cardiovascular, não há uma hipótese unificada para explicar o mecanismo molecular e celular, de como a Hcy influencia o desenvolvimento de DCV. Alguns eventos, como a lesão das células endoteliais, o aumento da adesão plaquetária, a ativação direta da cascata de coagulação maior deposição de LDL na parede arterial, têm sido emplicados na arterotrombogenicidade da hiperhomocisteinemia.

\subsubsection{Alterações da Tromborresistência Vascular}

O trabalho pioneiro de HARKER e cols. (1976) sugere que a início da alteração vascular, causada pela hiperhomocisteinemia, envolve a redução da sobrevida das plaquetas, associada à lesão das células endoteliais. Esta conclusão deve-se ao fato que lesões endoteliais causadas pela hiperhomocisteinemia, em animais, podem ser prevenidas pela terapia antiplaquetária com dipiridamol. No entanto, a sobrevida reduzida de plaquetas não foi confirmada em pacientes com homocistinúria. Outros trabalhos, in vitro, 
sobre função anormal das plaquetas mostraram resultados controversos (MAILINOW, 1994; STAMLER \& SIIVKA, 1996).

Por outro lado, favorecendo a teoria do aumento da atividade plaquetária pela hiperhomocisteinemia, estudos in vitro propõem que, além da citotoxicidade direta da Hcy sobre células endoteliais (DUDMAN e cols., 1991; STARKEBAUM \& HARLAN, 1986; WALL e cols., 1980) a Hcy alteraria propriedades antitrombóticas do endotélio (HARPEL e cols., 1996).

A prostaciclina $\left(\mathrm{PGI}_{2}\right)$ e óxido nítrico são dois fatores importantes no relaxamento vascular e na antiagregação plaquetária. Apesar de resultados controversos em relação à biossíntese de prostaciclina pelas células endoteliais incubadas com Hcy (GRAEBER e cols., 1982; PANGANAMALA e cols., 1986 e WANG e cols., 1993) postula-se que a Hcy estaria impedindo a habilidade das células endoteliais de inibir a agregação plaquetária, provavelmente pela redução da biodisponibilidade do óxido nítrico (STAMILER e cols., 1993).

Adicionalmente ao exposto acima, a exposição de monócitos à Hcy induz a expressão do fator tecidual (KHAJURIA \& HOUSTON, 2000). A exposição das células endoteliais à Hcy também aumenta a expressão do fator tecidual (FRYER e cols., 1993) além da ativação do fator V (RODGERS \& CONN,1990). UNDAS e cols. (2001) indicaram que a tendência pró-trombótica na hiperhomocisteinemia pode ser relacionada à inativação do fator Va pela ativação da proteina $C$, devido a uma modificação da cisteína livre do cofator na presença da Hcy. Todos os fatores descritos acima favorecem a formação do trombo pela iniciação e propagação da cascata de coagulação.

Além disso, a Hcy pode atuar sobre fatores anticoagulantes, como o sistema trombomodulina/proteína C e antitrombina III (LENTZ \& SADLER, 1991, 
1993). A ligação da antitrombina III à superfície das células endoteliais pode ser reduzida pela Hcy através da inibição da expressão de heparan-sulfato (NISHINAGA e cols., 1993).

Em relação ao processo de fibrinólise, a ação e ligação do ativador tecidual de plasminogênio (t-PA) na superfície celular do endotélio é prejudicado na presença de Hcy, inibindo a fibrinólise dependente do endotélio (HAJJAR, 1993).

A ligação dissulfeto entre a Hcy e o domínio rico em cisteína da anexina-Il é responsável pela inibição da ligação do t-PA à anexina-Il na superfície celular, prejudicando, consequentemente, a ativação do plasminogênio em plasmina e a degradação da fibrina, afetando o processo da fibrinólise (QI LING \& HAJJAR, 2000; HAJJAR e cols., 1998). MIDORIKAWA e cols. (2000) por outro lado, mostram que Hcy aumenta a secreção e expressão do gene inibidor tipo-1 da ativação do plasminogênio das células endoteliais e células do músculo liso, além da alteração na secreção e expressão do RNAm para t-PA.

Em conjunto, os dados acima expostos sugerem que a hiperhomocisteinemia favorece a trombogênese. A fim de confirmar este estado pró-trombótico, estudos clíricos, realizados em pacientes com hiperhomocisteinemia, revelam elevação anormal dos níveis plasmáticos de alguns parâmetros homeostáticos tais como, do fator VIII e do inibidor tipo-1 da ativação do plasminogênio (FERYBURGER e cols., 1997) do fator von Willibrand (VAN DEN BERG e cols., 1995; CONSTANT e cols., 1999) da trombomodulina (VAN DEN BERG e cols., 1995) do fibrinogênio (VON ECKARDSTEIN e cols., 1994) e do complexo III trombina/antitrombina e da proteína C ativa (CATTANEO, 1999; CATTANEO e cols.,1998). 
Dados mais encorajadores surgiram de experimentos in vivo que forneceram evidências que a hiperhomocisteinemia é responsável pela alteração da tromborresistência vascular. LENTZ (1997) e LENTZ e cols. (1996) demonstraram, na hiperhomocisteinemia experimental em primatas induzida por dieta sem ácido fólico, rica em metionina e sem colina, que a vasodilatação dependente do endotélio esta diminuída na hiperhomocisteinemia. Lentz verificou, igualmente, que o aumento da vasoconstrição induzida por colágeno é, provavelmente, devida à redução na resposta vasodilatadora ao ADP gerado pelas plaquetas. A alteração do relaxamento vascular mediado pelo endotélio também foi observada em indivíduos sadios, portadores de hiperhomocisteinemia moderada (TAWAKOL e cols., 1997; WOO e cols.,1997).

A diminuição da ativação da proteína C dependente da trombomodulina em primatas com hiperhomocisteinemia, sugere que o aumento moderado nos niveis circulantes de Hcy altera propriedades antitrombóticas do endotélio (LENTZ e cols. 1996). Estudos recentes, tanto em animais de laboratório como e humanos, sugerem fortemente que a hiperhomocisteinemia prejudica a vasodilatação dependente do endotélio (BELLAMY e cols., 1999; CHAMBERS e cols., 1999a, 1999b; KANANI e cols., 1999; UNGVARI e cols., 1999; WOO e cols., 1999)

LENTZ e cols. (1997 e 2001) verificaram que a normalização dos niveis plasmáticos de Hcy, após 6 meses de administração de ácido fólico, vitamina $B_{12}$ e $B_{6}$, foi insuficiente para restaurar a função vascular normal em macacos, mantidos por 17 meses com dieta hipercolesterolemica e hiperhomocisteinemica. Entretanto, dois estudos controlados por placebo demonstraram que a suplementação, durante dois meses, com ácido fólico, 
melhora a função endotelial em indivíduos com hiperhomocisteinemia, com diminuição nos níveis de Hcy (BELLAMY e cols., 1999; CHAMBERS e cols., 1999a, 1999b).

A administração conjunta de ácido fólico, vitaminas $\mathrm{B}_{12}$ e $\mathrm{B}_{6}$ melhora a função do endotélio, comprometida pela hiperhomocisteinemia induzida por sobrecarga de metionina em indivíduos sadios (CHAO e cols., 1999a). HOLVEN e cols. (2001) demonstraram que a Hcy tem o efeito aterogênico, em parte, por deprimir a função endotelial, através de mecanismo dependente de óxido rítrico e que este efeito pode ser revertido pela suplementação com ácido fólico.

Apoiando a hipótese do impacto da elevação moderada da Hcy plasmática e o estado de hipercoagulação, DURAND e cols. (1996b) demonstraram que a deficiência alimentar prolongada de ácido fólico em ratos induz estado pró-trombótico, caracterizado pela hiperatividade plaquetária. Adicionalmente, sugerem que os efeitos pró-trombóticos, causados pela deficiência do ácido fólico, depende do aumento da Hcy circulante.

Experimentos com sobrecarga de metionina, em animais controles e animais com deficiência de ácido fólico, indicam que a concentração plasmática de Hcy se correlaciona com a agregação plaquetária e com a biossíntese da tromboxano $A_{2}$, que é um potente pró-agregante, junto com a possibilidade de redução do efeito antiplaquetário do óxido nítrico (DURAND e cols., 1997a). Um aumento de tromboxano sintetase foi descrito em pacientes com homocistinúria (DI MINNO e cols., 1993) apoiando os achados acima descritos.

Os trabalhos descritos sugerem que a perda da função antitrombótica das células endoteliais, combinada com a indução do estado prócoagulante, contribuem para as desordens vasculares relacionadas à 
Introdução

hiperhomocisteinemia moderada. Adicionalmente às citações acima mencionadas, NAPPO e cols. (1999) enfatizam que a elevação moderada de Hcy circulante, relacionada ao metabolismo prejudicado de Hcy (resultante da deficiência de ácido fólico ou excesso de metionina) pode acionar desordens vasculares originadas pelo espasmo vascular ou trombose.

\subsubsection{Estresse Oxidativo Mediado pela Hiperhomocisteinemia}

Numerosos estudos indicam que o estresse oxidativo tem uma função no desenvolvimento de lesões ateroescleróticas oclusivas, como observado primeiramente em homozigotos com defeito de cistationa $\beta$ sintetase (MCCULLY, 1983) e, depois, em hiperhomocisteinemia experimental.

O dano celular das células endoteliais expostas à Hcy pode ser prevenido com pré-tratamento das células com catalase, a qual permite a retirada do peróxido de hidrogênio que atravessa livremente a membrana celular (STARKEBAUM \& HARLAN, 1986; WALL e cols., 1980). Entretanto esta citotoxicidade não é devida exclusivamente a Hcy. A lesão endotelial descrita também é observada na presença de cisteína (DUDMAN e cols., 1991). O aumento do estresse oxidativo pode ser o principal mecanismo na lesão das células endoteliais induzida pela Hcy (DUAN e cols, 2002).

Além da iniciação da lipoperoxidação na superfície da célula, a auto oxidação da Hcy, com traços de ions metálicos, leva à geração de espécies reativas de oxigênio, como ânion superóxido, peróxido de hidrogênio e radical hidroxila, assim como de radicais tiila (MUNDAY, 1989; SCHONEICH e cols., 1989). Estas espécies podem oxidar diretamente a lipoproteína de baixa 
densidade (LDL) (HEINECKE e cols., 1987; HIRANO e cols., 1994; WOOD \& GRAHAM, 1995).

A Hcy pode contribuir, também, para modificações oxidativas da LDL, mediadas pelas células endoteliais, macrófagos e células do músculo liso, envolvidos na etapa inicial da aterogênese (HEINECKE e cols., 1987; SPARROW \& OLSZEWSKI, 1993; WOOD \& GRAHAM, 1995).

Assim, o aumento da Hcy circulante, devido a alterações de seu metabolismo, pode favorecer um aumento no estado pró-oxidante. Nessas condições, os íons metálicos são mantidos na forma reduzida, ideal para a reação de Fenton. Isso pode alterar o potencial de redox dos grupos tióis, intra e extracelulares (MANSOOR e cols. 1993a, 1994, 1995).

Diferente de outros tióis, a incubação das células endoteliais com Hcy induz o aumento da expressão da proteína de estresse GRP78 e reduz a expressão da glutationa peroxidase, importante enzima antioxidante intracelular, por um mecanismo que depende da alteração do potencial redox intracelular (KOKAME e cols., 1996; OUTINEN e cols., 1998). Assim a Hcy, além de aumentar a geração de ânion superoxido, peróxido de hidrogênio e outros peróxidos, reduz a habilidade da célula de remover os peróxidos, especialmente o peróxido de hidrogênio.

Com isso, KOKAME e cols. (1996) sugerem que alterações no estado redox intracelular, causadas por níveis elevados de Hcy, podem alterar a expressão de vários genes envolvidos em outras funções celulares específicas, podendo ser, parcialmente responsável, por desordens vasculares associadas à hiperhomocisteinemia moderada. 
LANG e cols. (2000) apontam para uma inibição induzida pela Hcy no relaxamento dependente do endotélio, causada pelo aumento na produção endotelial de ânion superóxido. Os trabalhos de CHEN e cols., (2000) e UPCHURCH e cols. (1997) indicam que a Hcy inibe a glutationa peroxidase plasmática endotelial, prevenindo a retirada do peróxido de hidrogênio pela glutationa peroxidase, de maneira tal que a Hcy contribuiria, indiretamente, para a inativação do óxido nítrico por espécies reativas de oxigênio. De acordo com esta hipótese, a hiperhomocisteinemia moderada induz disfunção endotelial em camundongos heterozigotos para defeito da enzima CBS, que foi recentemente associada a um aumento de estresse oxidativo (EBERHARDT e cols., 2000).

Há forte evidências que o estresse oxidativo tem um papel importante na modificação da tromborresistência vascular, na hiperhomocisteinemia moderada. A disfunção endotelial, incluindo diminuição do relaxamento vascular dependente de células endoteliais, parece ser iniciada pela geração de espécies reativas durante a autoxidação da Hcy (LOSCALZO,1996).

Além disso, níveis elevados de Hcy têm sido associados com aumento de oxidação dos lipídios e proteínas in vivo, em humanos, como foi sugerido pela correlação obtida entre níveis plasmáticos de $\mathrm{Hcy}$ e $F_{2^{-}}$ isoprostanos, um relevante biomarcador da peroxidação não-enzimática (VENTURA e cols., 2000; VOUTILAINEN e cols., 1999).

A hiperhomocisteinemia moderada, causada pela alteração no metabolismo de Hcy (seja pela deficiência de ácido fólico, deficiência de vitamina $\mathrm{B}_{6}$ ou excesso de metionina) deve ter um efeito pró-oxidante primariamente resultante de uma alteração do potencial de redox intra e extracelular, afetando essencialmente as funções vasculares. 
Apesar da Hcy, em baixas concentrações e na sua forma reduzida, agir como pró-oxidante, em altas concentrações, como outros tióis, apresenta atividade seqüestradora de radicais livres (MUNDAY, 1989). Este efeito ambivalente dos aminotióis (pró e antioxidante) confirmado in vitro na oxidação da LDL (HALVERSEN e cols., 1996) talvez explique as discrepâncias observadas entre a hiperhomocisteinemia severa e a moderada.

Contrastando com a elevação moderada de Hcy, um grande aumento na Hcy circulante leva à elevação plasmática da razão entre aminotióis reduzidos/totais e entre Hcy e cisteína, deslocando o equilíbrio para o estado antioxidante (ANDERSON e cols., 1995; BOURDON \& BLACHE , 2001; UELAND e cols., 1996). Contudo, FERGUSON e cols. (1999) revelaram que a reação entre Hcy tiolactona e LDL gera um aduto de LDL mais resistente à oxidação do que a LDL nativa.

De fato, um mecanismo independente de estresse oxidativo deve estar envolvido na formação da lesão arteroesclerótica fibrosa, observada na hiperhomocisteinemia. Lesões vasculares descritas em estudos de homocistinúria devem ser resultantes do metabolismo oxidativo alternativo de Hcy a Hcy tiolactona (JACUBOWSKI, 1997 e 2000a). Este metabolismo, orientado para sintese de fosfoadenosina fosfossulfatos a partir de átomos de sulfato da Hcy tiolactona, deve levar à sulfatação excessiva de proteoaminoglicana da matriz extracelular, danificando a membrana basal da parede vascular e podendo, desta forma, contribuir ao seqüestro da LDL (MCCULLY,1996; OLSZEWSKI \& MCCULLY, 1993).

Apesar da ativação direta da metaloprotease-2 na matriz (BESCOND e cols., 1999) a lesão vascular deve resultar da alteração da estrutura 
quaternária da proteína no tecido conjuntivo. De fato, um defeito na polimerização do colágeno foi demonstrado em pacientes com homocistinúria devido à hiperhomocisteinemia (LUBEC e cols., 1996).

WANG e cols. (1997) descreveram que níveis de Hcy entre 10 e $50 \mu \mathrm{mol} / \mathrm{L}$ inibem, especificamente, o crescimento de células endoteliais. TASI e cols. $(1994,1996)$ descreveram que a Hcy é mitogênica para células musculares lisas em humanos e de ratos, pela indução da expressão da proteína ciclina $A$. Isto foi demonstrado em estudo in vivo no qual, a ingestão de Hcy por ratos estimula, de maneira dose dependente, a transcrição da quinase dependente de ciclina na aorta, necessária para a mitose e subseqüente proliferação das células do músculo liso.

Como a cisteína não influencia a transcrição do gene da quinase dependente da ciclina, as alterações vasculares podem ser específicas para Hcy. TYAGI (1998) demonstrou que $10 \mu \mathrm{mol} / \mathrm{L}$ de Hcy induz, em humanos, a proliferação das células de músculo liso vascular e a expressão de colágeno.

\subsubsection{Papel Alternativo de Hipometilação}

Uma explicação alternativa para doenças vasculares induzidas pela hiperhomocisteinemia é que níveis elevados de Hcy indicam uma ineficiência na metilação intracelular das reações essenciais, predispondo o organismo a doenças vasculares. Metilações intracelulares ineficientes levam à danificação crônica de inúmeras proteínas, que podem estar envolvidas na aterotrombogênese. Adicionalmente, níveis elevados de Hcy indicam biossíntese ineficiente de proteínas essenciais, causada por anormalidades no metabolismo de ácido fólico (DURAND e cols., 2001). 
Alem disso, o envolvimento da hipometilação não pode ser descartado, pelo fato de estudos in vitro sugerirem que, baixas concentrações de Hcy inibem, especificamente, a regeneração das células endoteliais e ativam diretamente células dormentes da musculatura vascular, por um mecanismo envolvendo decréscimo de carboximetilação da p21 ${ }^{\text {ras }}$ (LEE \& WANG, 1999, WANG e cols., 1997)

Dados recentes sugerem que elevação crônica dos niveis de Hcy deve, indiretamente, reduzir a metilação do DNA, RNA, proteínas e fosfolipídios através de um concomitante aumento nos níveis de $\mathrm{SAH}$, e que, este aumento é devido a inversão da reação da hidrólise de SAH que é mediada pela Hcy (YI e cols., 2000). Altos níveis de SAH estão efetivamente associados com diminuição de SAM, sendo que a razão SAM/SAH pode afetar negativamente o potencial da metilação celular (FU e cols., 2000; MELNYK e cols., 2000; YI e cols., 2000).

A ligação dissulfeto específica entre a Hcy e o grupo sulfidrila de uma proteína intracelular, pode constituir um outro mecanismo molecular para a disfunção endotelial induzida pela hiperhomocisteinemia. Junto com as proteínas do tecido conjuntivo, várias outras proteínas contêm domínios ricos em cisteina, como o fator de crescimento epidérmico, os quais podem ser sítios preferenciais de homocisteinização (KRUMDIECK \& PRINCE, 2000).

Os dados expostos sugerem que a elevação de Hcy resulta em efeitos multifatoriais, interagindo com a estrutura da parede vascular e com o sistema de coagulação, com diferentes resultados, dependendo do tecido e do grau de hiperhomocisteinemia. 


\subsubsection{Tratamento Vitamínico da Hiperhomocisteinemia}

A hiperhomocisteinemia pode ser reduzida significativamente, ou revertida, pelo tratamento de pacientes afetados com vitaminas, exceção feita aos defeitos severos de metionina sintetase ou da mutação termoestável de MTHFR. Nos últimos casos, a suplementação com betaína e/ou metionina deve ser realizada junto com a administração de ácido fólico ou 5-metilTHF (DURAND e cols., 2001).

Um grande número de estudos investiga o efeito benéfico da suplementação vitamínica sobre os níveis de Hcy (BRATTSTROM, 1996; QUINLIVAN e cols, 2002). Dados mostram que a suplementação com ácido fólico reduz a hiperhomocisteinemia em jejum e após a sobrecarga de metionina, incluíndo os pacientes com defeitos congênitos parciais de CBS e MTHFR. Os dados indicam, também, que a suplementação com piridoxina só reduz a hiperhomocisteinemia, detectada após sobrecarga oral de metionina, em pacientes com deficiência de vitamina $B_{6}$ ou heterozigotos para deficiência de CBS. O tratamento com vitamina $B_{12}$ seria eficiente, somente, nos casos de deficiência da vitamina.

O papel principal do ácido fólico na redução de níveis plasmáticos de Hcy pode ser explicado pelo fato que o ácido fólico é consumido durante o processo, enquanto que as vitaminas $B_{6}$ e $B_{12}$ funcionam como cofatores (DURAND e cols., 1998a, 1998b).

O consumo de ácido fólico, assim como sua concentração plasmática, apresenta correlação negativa com niveis plasmaticos de Hcy, tanto em indivíduos doentes como em indivíduos sadios (UBBINK, 1994; LUSSIERCACAN e cols., 1996). A suplementação com ácido fólico é o único tratamento 
que efetivamente reduz os níveis plasmáticos de Hcy em indivíduos sadios (BARTTSTROM,1996). Além disso, em contraste com a deficiência de vitamina $\mathrm{B}_{6}$, o aumento de risco aterosclerótico vascular associado à deficiência de ácido fólico é mediado pelo aumento de ríveis plasmáticos de Hcy (ROBINSON e cols., 1998).

As doses terapêuticas ideais ainda não estão claramente definidas. Para o ácido fólico, doses de 5 a 10 mg/dia são atualmente utilizadas. Entretanto, alguns dados sugerem que a administração diária de doses menores do que $1 \mathrm{mg}$ podem ser adequadas para reverter a hiperhomocisteinemia (BOUSHEY e cols., 1995; BRATTSTROM e cols., 1998; DEN HEIJER e cols., 1998; RIMM e cols., 1998).

Um trabalho de fortificação de grãos, contendo 499 e $665 \mu \mathrm{g}$ de ácido fólico, diariamente, aumentou os níveis plasmáticos de ácido fólico em $64,8 \%$ e $105,7 \%$, respectivamente, reduzindo os niveis plasmáticos de Hcy em $11 \%$ e 14\%, respectivamente (MALINOW e cols.,1998). Por outro lado, a meta-análise de BOUSHEY e cols.(1995) indicou que a suplementação diária com ácido fólico, em doses de $400 \mu \mathrm{g}$, pode induzir um decréscimo de $6 \mu \mathrm{mol} / \mathrm{L}$ nos níveis plasmáticos de Hcy, prevenindo 28.000 mortes/ano de infarto de miocárdio.

Trabalhos recentes indicam que a terapia com ácido fólico, na dose diária de 0,5mg, é o menor nivel efetivo para a redução dos níveis de Hcy, em jejum e após sobrecarga de metionina, em indivíduos com hiperhomocisteinemia (CLARKE \& ARMITAGE, 2000; VAN DER GRIEND e cols., 2000). A terapia somente com vitamina $B_{6}$ não reduz os níveis de Hcy em jejum. Altas doses de vitamina $\mathrm{B}_{6}$ (30 a $\left.100 \mathrm{mg} / \mathrm{dia}\right)$ são necessárias no tratamento de defeitos hereditários como do cistationina $\beta$ sintetase ou a deficiência severa desta 
vitamina. Finalmente, 0 tratamento com vitamina $B_{12}$ pode ser necessário somente em situações de deficiência desta vitamina, com doses de 0,4 a 2 $\mathrm{mg} / \mathrm{dia}$, dependendo da gravidade da deficiência.

Alguns estudos mostram que a suplementação com ácido fólico melhora a função endotelial em indivíduos com hiperhomocisteinemia (BELLAMY e cols., 1999; WOO e cols., 1999). Dados encorajadores de trabalhos recentes indicam o benefício da terapia de redução de Hcy na prevenção e correção das desordens vasculares, relacionadas a níveis elevados de Hcy. Como foi descrito acima, o tratamento conjunto com ácido fólico e piridoxina deve efetivamente contribuir para redução do risco de aterotrombose (DE JONG e cols., 1999; HACKMAN e cols., 2000; VERMEULEN e cols., 2000; YAP e cols.,2000).

Estudos coerentes e prospectivos, em indivíduos sadios, resultantes de investigações com intervenção controlada por placebo, duplo-cego e multicêntricos, são necessários para definir a eficiência das terapias na redução dos niveis de Hcy e a conseqüente diminuição das patologias associadas, na prevenção e correção das desordens em pacientes com artéria coronária oclusiva, de doenças cerbrovasculares e vasculares periféricas e da trombose relacionada à hiperhomocisteinemia. 
OBJETIVOS 


\section{OBJETIVOS}

1. Avaliar as correlações entre a injetão e os níveis plasmáticos de vitamina $\mathrm{B}_{6}, \mathrm{~B}_{12}$ e ácido fólico.

2. Avaliar os níveis plasmáticos de Hcy em duas populações, Uma de residência urbana e outra rural, e sua correlação com níveis plasmáticos das vitaminas $B_{6}, B_{12} e$ ácido fólico.

3. Verificar a prevalência de Hiperhomocisteinemia e dislipídemia, como fator de risco de doença cardiovascular, nas duas populações. 
MATERIAIS E MÉTODOS 


\section{MATERIAIS E MÉTODOS}

\subsection{SELEÇÃO DOS VOLUNTÁRIOS PARA PESQUISA}

Foram selecionados 171 voluntários saudáveis, sem nenhum problema cardiovascular caracterizado e de vida dentro dos padrões considerados normais.

A idade dos voluntários que participaram neste trabalho foi entre 30 e 60 anos, faixa de idade em que surgem os problemas cardiovasculares (mww.saude.gov.br). Indivíduos acima de 70 anos foram excluídos por apresentarem $30 \%$ de aumento nos niveis de Hcy (BJORKERGERN \& SVARDSUDD, 2001).

Dos 171 voluntários, 85 habitam a região urbana de São José dos Campos, SP, sendo que 28 dos voluntários são do sexo masculino e 57 do sexo feminino. Da região rural de Bragança Paulista, SP, vieram 86 voluntários, sendo 46 do sexo masculino e 39 do sexo feminino. Foi considerado indivíduo urbano aquele que vive na cidade, onde a maioria mora em apartamentos, tem um estilo de vida mais agitado, todos os alimentos têm que ser comprados e estão mais sujeitos a restaurantes do tipo "fast food". $\mathrm{O}$ indivíduo rural é aquele que trabalha na lavoura com a plantação, geralmente vive em casa com horta, come comida caseira na maioria das vezes, tem horários para se alimentar e possui menos disponibilidade de restaurantes do tipo "fast food".

Todos os voluntários assinaram o Termo de Consentimento Livre e Esclarecido (anexo1). O protocolo de estudo aprovado pelo Comitê de Ética em Pesquisa da Universidade São Francisco (sob nº, anexo II). 


\subsection{METODOLOGIA PARA ESTIMAR CONSUMO DIÁRIO DAS VITAMINAS}

\subsubsection{Inquérito Alimentar}

O inquérito alimentar objetiva quantificar a ingestão de vitaminas que atuam como cofatores no metabolismo da homocisteína, permitindo correlacionar o aporte dietário dessas vitaminas, com os niveis de homocisteína no sangue. Considerando que vários fatores interferem com os niveis séricos de homocisteína, dentre as quais fatores genéticos e a disponibilidade de vitaminas do metabolismo da homocisteína. O conhecimento dos hábitos alimentares das populações rurais e urbanas permite correlacionar o consumo dessas vitaminas com os níveis séricos de homocisteína e o risco cardiovascular dessas populações.

\subsubsection{O Inquérito Alimentar e Sua Aplicação}

A montagem do inquérito inicial (anexo III) foi baseada nos alimentos consumidos pela população em geral, que contêm as vitaminas $B_{6}, B_{12}$ e ácido fólico. A fonte utilizada na montagem deste inquérito foi a forma resumida da RDA (Recommended Dietary Allowances) como descrito por MARKS \& MARKS (1996) BETTIN (1994) BLOCK (1982) BLOCK e cols. (1990) ECK \& WILLET (1991) e ECK e cols. (1991).

Os resultados da aplicação piloto do inquérito inicial (anexo 3) a 12 indivíduos de residência urbana revelaram que alguns dos alimentos propostos no inquérito inicial eram pouco consumidos e/ou apresentavam baixos teores das vitaminas do metabolismo da homocisteína, como por exemplo, o agrião, evidenciando a necessidade de alteração do inquérito. Novo inquérito foi, então, 
organizado, substituindo alguns alimentos por outros mais consumidos e/ou com maior teor de vitaminas, como por exemplo a substituição do agrião por alface.

Como a preservação das vitaminas nos alimentos depende do seu preparo, é de vital importância conhecer a forma de consumo, para que, posteriormente, possamos calcular a quantidade exata desses vitaminas consumidas pelos individuos em estudo. Outro ponto crítico diz respeito à quantidade de alimento consumido, principalmente quando as pessoas argüidas são humildes (rurais ou mesmo urbanos) e habituadas a quantificar alimentos de forma peculiar e regional.

Embora a quaritidade de alimentos consumidos e seus métodos de preparo sejam de extrema importância para o inquérito, um cuidado especial foi tomado quanto a não induzir o indivíduo em sua resposta; neste caso em que o inquérito perderia o seu valor como referência para quantificar o consumo das vitaminas. Foi também limitada o número de inquéritos (máximo de 5 por dia), e estabelecendo-se intervalos de meia hora entre os participantes para responder os inquéritos, evitando-se uma possível indução de resposta entre os voluntários, quanto aos seus hábitos alimentares.

Após ponderar sobre todos os pontos descritos acima, a versão revisada que chamamos de inquérito 2 (anexo IV) foi aplicada aos voluntários selecionados das regiões urbana e rural.

\subsubsection{Cálculo das Vitaminas $B_{6}$ e $B_{12}$ e de Ácido Fólico}

Os dados obtidos a partir dos inquéritos foram processados utilizando o Programa de Apoio à Nutrição (PAN) desenvolvido pelo Centro de Informática em Saúde (CIS) da UNIFESP-EPM. O cálculo das quantidades das 
vitaminas $B_{6}, B_{12}$ écido fólico consumidas semanalmente pelos participantes, foi realizado como se segue:

1. Utilizando-se o PAN, verificou-se a quantidade de vitaminas contida em $100 \mathrm{~g}$ de cada alimento, conforme o modo de preparo (Por exemplo, $100 \mathrm{~g}$ de frango, assado, cozido ou frito, contendo certa quantidade de vitamina $\mathrm{B}_{6}, \mathrm{~B}_{12}$ e ácido fólico).

2. Em seguida, transformamos todas as medidas caseiras em gramas. Por exemplo, um copo de requeijão de leite corresponde a $250 \mathrm{~g}$ de leite. A transformação das medidas caseiras em gramas também foi feito com o auxilio do PAN.

3. Após a transformação de todas as medidas em gramas, calculou-se a quantidade total de cada alimento ingerido por semana pelo participante,

4. A partir da quantidade total de alimento ingerido, foi então calculada a quantidade de vitaminas consumida através de cada alimento utilizando os dados da etapa 1.

5. A soma da quantidade de vitaminas ingerida através de cada alimento foi somada, resulta no o total de vitaminas consumidas por semana.

Exemplo:

1. De acordo com PAN, cada $100 \mathrm{~g}$ de frango frito contem se $0,35 \mu \mathrm{g}$ de $\mathrm{B}_{12}$, $0,39 \mathrm{mg}$ de $\mathrm{B}_{6}$ e $9 \mu \mathrm{g}$ de ácido fólico.

2. Pelo inquérito alimentar, o participante rural \#1 consome 2 pedaços (uma asa e uma coxa) de frango frito, 3 vezes por semana. O peso estipulado pelo PAN de uma asa é de $33 \mathrm{~g}$ e da coxa é $46 \mathrm{~g}$, calculando totalizando 237gramas de frango frito por semana. 
3. Corrigindo a quantidade de vitaminas contida no frango pela quantidade de frango consumido, temos que este participante ingere $0,816 \mathrm{mg}$ de vitamina $B_{6}, 21,6 \mu g$ de ácido fólico e $0,84 \mu g$ de vitamina $B_{12}$ em seu consumo semanal de frango.

4. Somados aos valores obtidos de todos outros alimentos listados no inquérito alimentar deste participante, totalizando um consumo semanal de $1.62 \mathrm{mg}$ de vitamina $B_{6}, 215,3 \mu \mathrm{g}$ de ácido fólico e $17,8 \mu \mathrm{g}$ de vitamina $B_{12}$.

\subsection{METODOLOGIA PARA MEDIR NÍVEIS PLASMÁTICOS DAS VITAMINAS}

\subsubsection{Dosagem de Vitamina $B_{12}$}

A cianocobalamina, ou vitamina $B_{12}$, tem larga distribuição na natureza e exerce importante papel no metabolismo animal. Nem os vegetais, nem os animais conseguem sintetizar a vitamina $\mathrm{B}_{12}$, a qual é produzida apenas por certas bactérias. A maior fonte de vitamina $B_{12}$ são alimentos protéicos como carne, ovos e leite. A vitamina $B_{12}$ está envolvida no metabolismo da homocisteína, participando da transferência do grupo metil do tetrahidrofolato para homocisteína, formando metionina, evidenciando sua importância na dieta humana no que diz respeito à manutenção do metabolismo da homocisteína e à prevenção da hiperhomocisteinemia como fator de risco cardiovascular. Neste sentido, a reciclagem da homocisteína a metionina requer a vitamina $B_{12}$, como descrito por vários autores que relacionaram os baixos níveis plasmáticos das vitaminas $\mathrm{B}_{6}, \mathrm{~B}_{12}$ e ácido fólico com aumento da homocisteína (PANCHARUNITI, e cols. 1994; GUTHIKONDA \& HAYNES, 1999; LANGMAN \& COLE, 1999; EIKELBOOM, e cols. 1999; RAY e cols., 2000; CHAMBERS e cols., 2000; 
CLARKE \& ARMITAGE, 2000; SAW e cols., 2001; BJORKEGERN \& SVARDSUDD, 2001; HERRMANN e cols., 2001; FOKKEMA e cols., 2001).

As amostras de sangue foram obtidas dos individuos em jejum, com sistema de coleta a vácuo (vacuntainer) em tubo seco e o soro obtido após retração do coágulo e centrifugação . O soro foi armazenado a $-70^{\circ} \mathrm{C}$ até a sua utilização. Todas as etapas descritas foram conduzidas na ausência de luz, utilizando-se eppendorf escuro ou com proteção de papel alumínio, de forma a minimizar a degradação da vitamina.

A dosagem de vitamina $B_{12}$ foi conduzida pelo método de quimioluminescência direta, onde a vitamina $B_{12}$ das amostras compete com a vitamina $B_{12}$ marcada com éster de acridínio, em reagente Lite (vitamina $B_{12}$ marcada com éster de acridina em solução tamponada com azida sódica $0.1 \%$, estabilizadores de proteína, e conservantes). O ensaio utiliza hidróxido de sódio e ditiotreitol, como agente liberador da vitamina $B_{12}$ ligada a proteínas endógenas, e cobalamida, para prevenir a religação da vitamina $\mathrm{B}_{12}$ às proteínas. As leituras de quimioluminescência foram levadas e efeito em aparelho Chiron Diagnostics ACS:Centaur (Bayer). Os kits e o uso dos equipamentos necessários às dosagens foram cedidos como cortesia pela Análise Produtos e Serviços para Laboratórios Ltda.

\subsubsection{Dosagem de Vitamina $\mathrm{B}_{6}$ e Ácido Fólico}

A vitamina $B_{6}$ funciona como coenzima essencial para mais de 50 reações envolvendo o metabolismo de proteínas e síntese, transformação e degradação de aminoácidos, além de contribuir para síntese de neurotransmissores e produtos aminados, como a histamina. Pelo fato da vitamina $\mathrm{B}_{6}$ contribuir para uma variedade diferente de reações, sua deficiência 
resulta em várias alterações patológicas, como problemas motores, anemia e depressão, entre outras, além da hiperhomocisteinemia e aumento do risco de doença cardiovascular (SELHUB e cols., 1993; SAW e cols., 2001; KOEHLERE e cols., 2001).

O ácido fólico atua como cofator de várias reações do metabolismo intermediário e do processo de depressão (ALPERT \& FAVA, 1997), além de estar envolvido no metabolismo da homocisteína. O nível de ácido fólico, medido tanto como consumo da dieta ou diretamente do soro, é inversamente associado ao risco de doenças cardiovasculares (BERG \& BOERS, 1996; LORIA e cols., 2000; O'LEARY \& SHEEHY, 2001; WALD e cols., 2001; KOEHLERET e cols., 2001; CHAMBERS e cols., 2000; CLARKE \& ARMITAGE, 2000; SAW e cols., 2001; BJORKEGERN \& SVARDSUDD, 2001).

A quantificação da vitamina $B_{6}$ e do ácido fólico foi realizada utilizando técnicas de cromatografia líquida de alta eficiência. Inicialmente, para dosagem de vitamina $B_{6}$, seguimos a metodologia descrita por SHARMA $E$ DAKSHINAMURTI (1992) e a proposta inicial para dosagem de ácido fólico era a utilização do método descrito por BELZ e cols. (1994) e KELLY e cols. (1996). Contudo, verificando os trabalhos de GREGORY III e cols. (1994), TELLINGEN \& SIPS. (1992), VAHTERISTO e cols. (1997) e VAHTERISTO e cols. (1997), chegamos à conclusão que poderíamos utilizar o mesmo processo de extração e fase cromatográfica para quantificação das duas vitaminas simultaneamente.

As amostras de sangue foram obtidas dos indivíduos em jejum, com sistema de coleta a vácuo (vacuntainer) em tubo heparinizado, foram imediatamente centrifugadas e o plasma obtido foi armazenado a $-70^{\circ} \mathrm{C}$ até a sua utilização. Tanto as amostras como as soluções padrão de ácido fólico $(0,5 \mathrm{mg} / \mathrm{dL})$ 
e de vitamina $B_{6}(0,5 \mathrm{mg} / \mathrm{dL})$ foram submetidas ao processo de extração: $300 \mu \mathrm{L}$ ácido metafosfórico $10 \%$ e $100 \mu \mathrm{L}$ de plasma (ou padrão) foram mantidos sob agitação por 30 segundos e centrifugados por 20 minutos a $-4^{\circ} \mathrm{C}$ com 10000 rpm. O extrato foi filtrado em sistema eppendorf com filtro (20 $\mu$ ) ("Castor spin-X TM centrifuge filter unit") antes de serem injetados no sistema.

Todas as etapas da extração foram conduzidas em ambiente escuro, utilizando-se tubos eppendorf escuros ou protegidos com papel alumínio, de maneira a minimizar a degradação das vitaminas. Como descrito na literatura, apesar da vitamina $B_{6}$ ser estável em meio ácido, SAMPSON O’CONNER (1989) verificou que o padrão de vitamina $\mathrm{B}_{6}$ em meio ácido metafosfórico $5 \%$, a $4^{\circ} \mathrm{C}$, sofre degradação de $0,09 \% / h$ durante as primeiras 40 horas e, a seguir, permanece estável por 233 horas. Soluções de padrão de vitamina $B_{6}$ e ácido fólico, assim como amostras extraídas, foram mantidas a $-4^{\circ} \mathrm{C}$ até o momento de injetar no HPLC.

O processo cromatográfico foi conduzido utilizando-se detector UV visível (UV-100) e bomba modelo P100 isocrática da Thermo Separation Products, com injetor modelo Rheodyne modelo 7725 acoplado a coluna $C_{18} \mu$ bondapack da Waters. A coluna foi estabilizada com fase móvel, contendo $18 \%$ de acetonitrila e $0,2 \%$ de ácido metafosfórico, em água milliQ. A separação e identificação das vitaminas foram conduzidas na fase descrita, com fluxo de $1 \mathrm{~mL} /$ minuto; o tempo de retenção foi de 2,93 e 4,09 minutos para a vitamina $\mathrm{B}_{6} \mathrm{e}$ o ácido fólico respectivamente.

O perfil cromatográfico dos padrões da vitamina $\mathrm{B}_{6}$ e ácido fólico na concentração de $1 \mathrm{mg} / \mathrm{dL}$ separadamente e o perfil cromatográfico da mistura de partes iguais de vitamina $B_{6}$ e ácido fólico se encontram, respectivamente, na 
figura $3(a, b$ e c ) . A concentração plasmática das vitaminas foi calculada em relação aos padrões de vitamina $\mathrm{B}_{6}(1 \mathrm{mgdL})$ e ácido fólico (1mg/dL).

\subsection{DETERMINAÇÃO DA CONCENTRAÇÃO DA HOMOCISTEINA}

\section{PLASMÁTICA}

A determinação da homocisteína foi introduzida nos laboratórios de diagnóstico clínico em 1962, quando o primeiro paciente com erro genético para homocistinúria foi descrito. O progresso nas pesquisas envolvendo a homocisteína nos últimos anos tem facilitado a introdução de técnicas mais aperfeiçoadas para a medida de Hcy no plasma e soro (ARAKI e SAKO, 1987; UBBINK e cols., 1991; VESTER e cols., 1991; CORNWELL e cols., 1993; JACOBSON e cols., 1994). Estes métodos medem tHcy, que é a soma da Hcy livre e da ligada a proteínas. A principal vantagem destes métodos é que as amostras guardadas podem ser analisadas sem que ocorra alteração na tHcy, mesmo quando as mesmas são congeladas e guardadas por alguns anos (UELAND, 1993; CANDITO e cols., 1997; PERRY, 1999; GRIEND e cols., 2000). 
Figura 3- Perfis cromatograficos de soluções padrões de vitaminas B6 1mg/dL (1a), ácido fólico $1 \mathrm{mg} / \mathrm{dL}$ (1b) e da mistura de partes iguais destas soluções (1c).

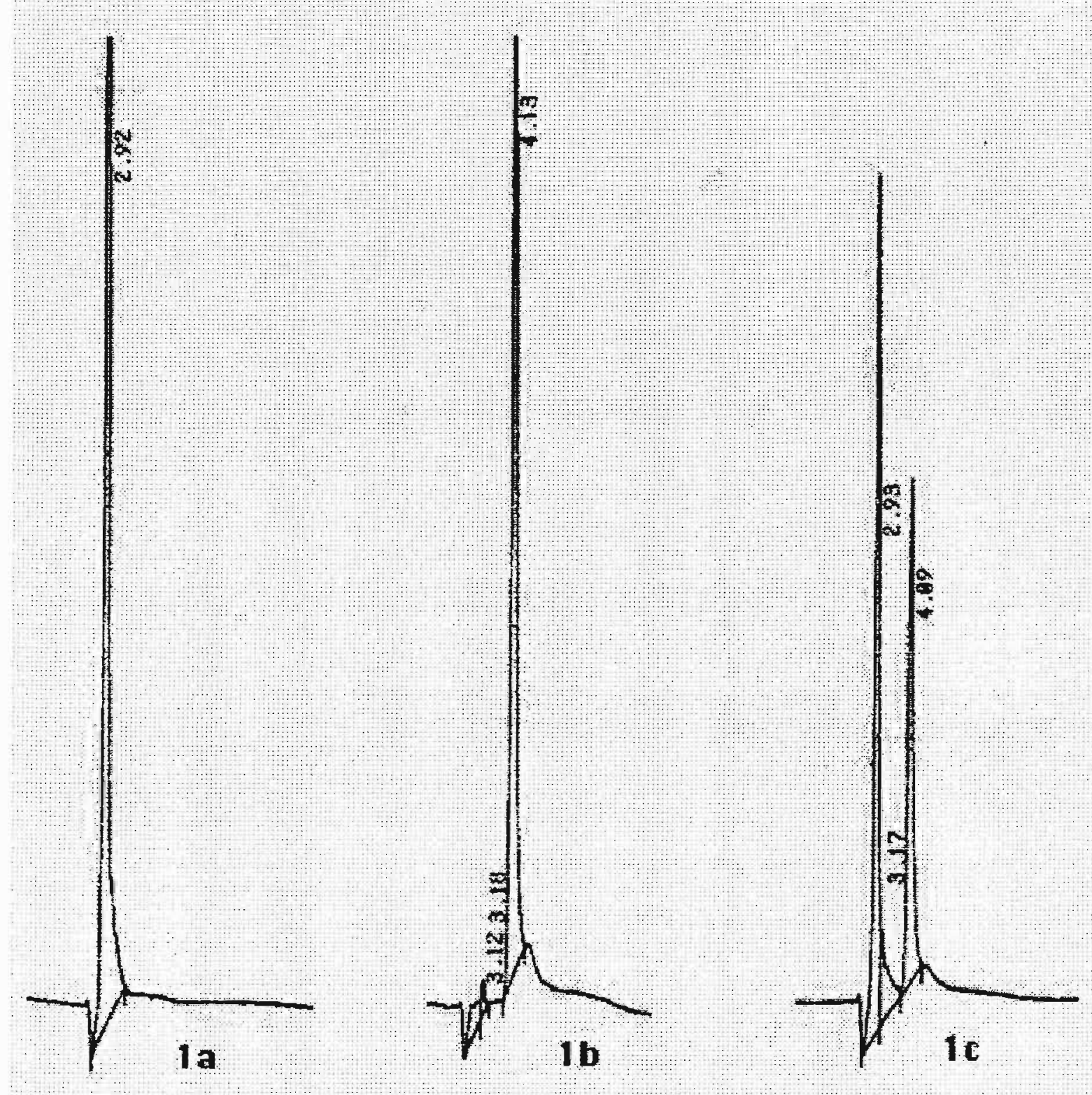




\subsubsection{Obtenção da Amostra}

As amostras de sangue, foram obtidas dos indivíduos em jejum, com sistema de coleta a vácuo (vacuntainer) em tubo heparinizado, centrifugadas imediatamente após e o plasma obtido, armazenado a $-70^{\circ} \mathrm{C}$ até sua utilização. A condição de jejum foi estabelecida uma vez que os estudos sobre a influência do consumo de alimentos sobre os níveis de Hcy são escassos e contêm dados conflitantes. As alterações na Hcy plasmática, induzidas experimentalmente pela dieta em indivíduos sadios, variam em um aumento de 8 a 14\% (UBBINK e cols., 1992). GRIEND e cols. (2000) investigaram alterações fisiológicas de Hcy em indivíduos sadios, com idade média de 33 anos, utilizando amostras de sangue coletadas às $8: 00,11: 00,15: 00$ e 20:00h, por dois dias consecutivos. Durante estas coletas, os indivíduos não tinham restrição de dieta ou atividades. O valor médio encontrado para Hcy foi de $11,7 \pm 2.2 \mu \mathrm{mol} / \mathrm{L}$, com um coeficiente de variação de 19\%. BERG e cols. (1999) e GARG e cols. (1997) revelam que a variabilidade interindividual entre tempo e Hcy no jejum vai de 7 a $25 \%$.

A coleta e o processamento das amostras de sangue são etapas críticas na determinação da Hcy. A amostra coletada foi sempre rapidamente centrifugada e o plasma separado dos elementos figurados. A rapidez neste processo é necessária já que a Hcy no plasma pode ser aumentada pela liberação de Hcy dos eritrócitos, que ocorre dependendo do tempo e da temperatura. Os valores de tHcy obtidos do soro sangüíneo, separado a $4^{\circ} \mathrm{C}$ imediatamente após a coleta, são iguais aos obtidos de amostras coletadas e guardadas por até uma hora, a $4^{\circ} \mathrm{C}$, antes da separação. Porém, após um tempo

prolongado de incubação a $4^{\circ} \mathrm{C}$, de 4 a 24 horas antes da separação, a Hcy aumenta de $61 \%$ a $175 \%$, respectivamente; uma média de aumento 15 a $20 \%$ por 
hora é obtida à temperatura ambiente. Uma vez que o sangue é separado dos eritrócitos, concentrações da Hcy no plasma são estáveis pelo menos até 4 dias a temperatura ambiente, 2 semanas a $0-2^{\circ} \mathrm{C}$ e vários anos a $-20^{\circ} \mathrm{C}$ (ANDERSON e cols., 1992; UELAND e cols., 1993; MALINOW e cols., 1994; NYGARD e cols., 1999).

\subsubsection{Técnica da Dosagem da Homocisteína}

Apesar de existirem vários métodos, a dosagem de Hcy por HPLC baseada na derivatização com reagente fluorogênico tiol-específico, o SBD-F (ammonium 7-fluorobenzo-2oxa-1,3 diazole-4-sulfonato), tem sido a mais utilizada. Este método foi primeiramente introduzido por ARAKI e SAKO (1987) que utilizaram tri-n-butilfosfina como agente redutor de tiol e como desacoplador das proteínas. UBBINK (1991), melhorou a técnica, mudando a fase móvel de gradiente de eluição para condições isocráticas. Mais tarde, VESTER e RASMUSSEN (1991) usaram um padrão interno de mercaptopropionil-glicina, que alterou o tempo de análise para 25 min. Este padrão interno foi trocado por $\mathrm{N}$ acetilcisteína, que permitiu a separação rápida (12 min) por DURAND e cols. (1996). Este método foi ainda melhorado com a introdução de um novo agente redutor, a tris(2-carboxietil) fosfina (TCEP) por GILFIX, em 1997.

Utilizamos a técnica de HPLC com detecção de fluorescência, como descrito por PFEIFFER e cols. (1999) que combina todos fatores desejáveis: a) estabilidade, eficiência e a presença de um agente redutor não tóxico; b) incorporação de padrão interno apropriado; c) rápida separação isocrática do tiol de interesse, usando fase móvel de $\mathrm{pH} 5,5$. O método pode ser usado com 
plasma, soro ou outros fluidos biológicos. As principais etapas do processo estão descritos a seguir:

1. Etapa de Redução: $50 \mu \mathrm{L}$ de plasma heparinizado, de doadores em jejum, foram transferidos para tubo eppendorf e acrescidos de $25 \mu \mathrm{L}$ de tampão PBS ("tampão fosfato salino" em $\mathrm{pH} 7,4$ ), $25 \mu \mathrm{L}$ de padrão interno (cistamina $40 \mu \mathrm{M} / \mathrm{L}$ ) e 10 $\mu \mathrm{L}$ de TCEP (tris2-carboxietil fosfina 10\%). O material foi homogeneizado em vórtex por 30 segundos e incubado a temperatura ambiente por 30 minutos.

2. Etapa de Precipitação: Em seqüência à etapa de redução, foi adicionado ao mesmo eppendorf, $100 \mu \mathrm{L}$ de TCA $10 \%$ contendo $1 \mathrm{mM}$ de EDTA. O conteúdo do eppendorf foi homogenizado em vórtex por 30 segundos e centrifugado por 10 minutos a $13.000 \mathrm{~g}$.

3. Etapa de Derivatização: $50 \mu \mathrm{L}$ do sobrenadante da etapa de precipitação foram transferidos para um eppendorf âmbar e acrescidos de $10 \mu \mathrm{L}$ de $\mathrm{NaOH} 1,55 \mathrm{M}, 125 \mu \mathrm{L}$ de tampão borato $0,125 \mathrm{M}, \mathrm{pH} 9,5$, contendo EDTA

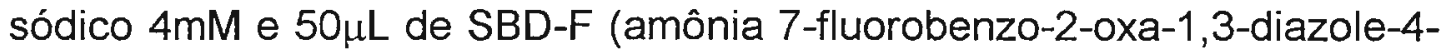
sulfonato) $0,4 \%$, diluído em tampão borato $\mathrm{pH} 9,5 . \mathrm{O}$ conteúdo foi homogeneizado em vórtex por 30 segundos e incubado por 60 minutos a $60^{\circ} \mathrm{C}$

4. $10 \mu \mathrm{L}$ da etapa de derivatização foi cromatografada em HPLC. A homocisteína foi eluida com tampão ácido acético/acetato $0,1 \mathrm{M}, \mathrm{pH} 5,5$, contendo $3 \%$ de metanol, com fluxo de $0,7 \mathrm{~mL} /$ minuto. A homocisteína foi determinada utilizando um detector de fluorescência com $\lambda$ de excitação $=$ $385 \mathrm{~nm}$ e de emissão=515 nm. As dosagens foram conduzidas em Sistema Shimadzu Modelo FIL-10A dvp, com bornba e detector RF-10AXL, 
utilizando coluna Prodigy ODS2 de $150 \times 3,2 \mathrm{~mm}$ com micropartículas de $5 \mu \mathrm{m}$ (Phenimenex) e pré-coluna Adsorbosphere $C_{18}$ de $7,5 \times 4,6 \mathrm{~mm}$, com micropartículas de $5 \mu \mathrm{m}$ de Alltech. Dentro das condições cromatográficas descritas, o tempo de retenção de homocisteína é de 3,62 minutos. O perfil cromatográfico da homocisteina da amostra se encontra na figura 4.

5. Para o cálculo da concentração da homocisteína, foi utilizada curva de calibração com concentrações crescentes e conhecidas de homocisteina: $3,125 \mu \mathrm{M}, 6,25 \mu \mathrm{M}, 12,5 \mu \mathrm{M}, 25,0 \mu \mathrm{M}$ e $50,0 \mu \mathrm{M}$ e com o padrão interno cistamina, na concentração constante de $10 \mu \mathrm{M}$.

Figura 4- Perfil cromatografico da homocisteina na amostra.

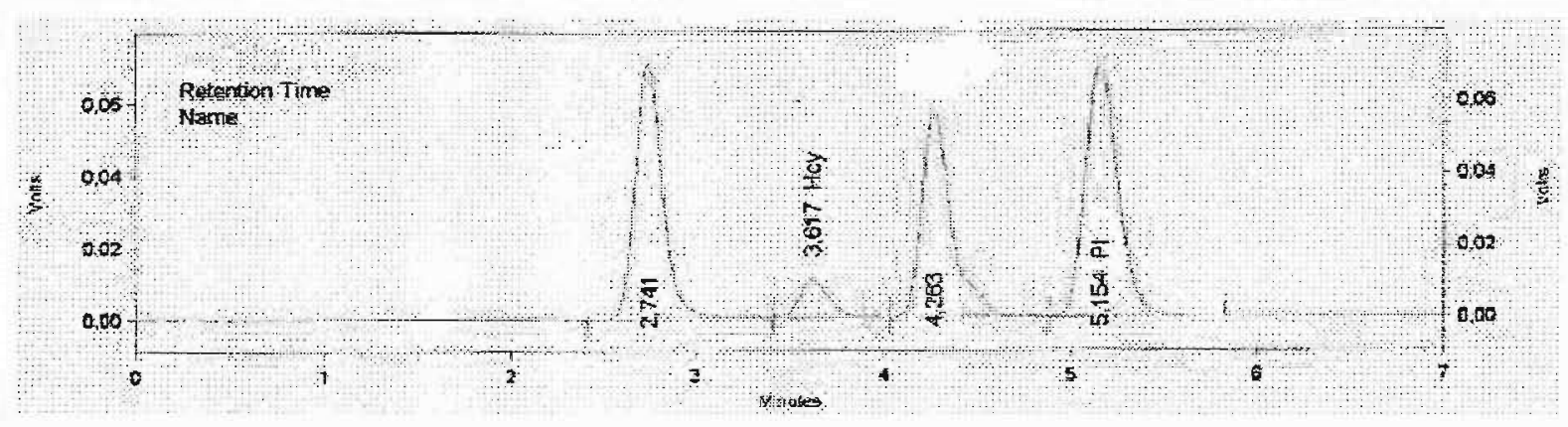




\subsection{METODOLOGIA PARA AVALIAR NÍVEIS PLASMÁTICOS DOS LIPÍDEOS}

\subsubsection{Dosagem de Triglicerídios}

A concentração dos triglicerídios é influenciada por hábitos dietéticos. A determinação dos triglicerídios fornece um dado importante e necessário para a classificação das dislipídemias. É também de importância a intima correlação que se observa entre a hipertrigliceridemia e o aumento de risco de doença coronariana.

As amostras de sangue foram coletadas com sistema de coleta a vácuo em tubo seco (vacutainer) e o soro foi obtido após a centrifugação do sangue coagulado. $\mathrm{O}$ soro então foi armazenado a $-70^{\circ} \mathrm{C}$ até a sua utilização.

Utilizou-se um sistema enzimático para a determinação dos triglicerídios com reação de ponto final. As reações envolvidos no método são:

\begin{tabular}{||l}
\hline Trigliceridios $\underset{\text { Liporoteina }}{\longrightarrow}$ Glicerol + Ácidos Graxos \\
Glicerol + ATP $\stackrel{\text { Gliceroquinase }}{\longrightarrow}$ Glicerol-3-fosfato + ADP \\
Glicerol-3-Fosfato $+\mathrm{O}_{2} \stackrel{\text { Glicerol-3-Fosfato }}{\text { Quinase }}$ Dihidroxiacetona $+\mathrm{H}_{2} \mathrm{O}_{2}$ \\
$\mathrm{H}_{2} \mathrm{O}_{2}+$ 4Aminoantipirina + ESPAS $\stackrel{\text { Peroxidase }}{\longrightarrow}$ Quinonimina $+4 \mathrm{H}_{2} \mathrm{O}$ \\
\hline
\end{tabular}

A quinonimina produzida na reação catalizada pela peroxidase tem máximo de absorbância em 540nm. A intensidade da cor violeta resultante é diretamente proporcional à concentração dos triglicerídios na amostra. As 
dosagens foram realizadas empregando kits da LABTEST Diagnóstica (Triglicérides GPO-ANA) e as leituras, em espectrofotômetro Beckman DU 640.

\subsubsection{Dosagem de Colesterol Total}

As amostras de sangue foran coletadas utilizando um sistema de coleta a vácuo em tubo seco (vacutainer) e o soro foi obtido após a centrifugação do sangue coagulado. $\mathrm{O}$ soro foi armazenado a $-70^{\circ} \mathrm{C}$ até a sua utilização.

Utilizou-se um ensaio enzimático para determinação do colesterol com reação de ponto final, conforme o esquema abaixo:

\begin{tabular}{||l}
\hline Esteres de Colesterol $\underset{\text { Esterase }}{\stackrel{\text { Colesterol }}{\longrightarrow}}$ Colesterol + Ácidos Graxos \\
Colesterol $+\mathrm{O}_{2} \stackrel{\text { Colesterol }}{\text { Oxidase }} \longrightarrow$ Colest-4-en-ona $+\mathrm{H}_{2} \mathrm{O}_{2}$ \\
$2 \mathrm{H}_{2} \mathrm{O}_{2}+$ Fenol +4 -Aminoantipirina $\stackrel{\text { Peroxidase }}{\longrightarrow}$ Antipirilquinonimina $+4 \mathrm{H}_{2} \mathrm{O}$ \\
\hline
\end{tabular}

A antipirilquinonimina produzida na reação catalizada pela peroxidase tem máximo de absorbância em 500nm. A intensidade de cor vermelha resultante da reação final é diretamente proporcional à concentração de colesterol na amostra. As dosagens foram realizadas utilizando kits da LABTEST Diagnóstica (Colesterol COD-ANA) e as leituras em espectrofotômetro Beckman DU 640. 


\subsubsection{Dosagem de HDL Colesterol}

As amostras de sangue foram coletados utilizando-se o sistema de coleta a vácuo seco (vacutainer) e o soro foi obtido após a centrifugação do sangue coagulado. O soro foi armazenado a $-70^{\circ} \mathrm{C}$ até a sua utilização. A dosagem foi realizada utilizando um sistema que precipita seletivamente as lipoproteínas LDL e VLDL, com determinação do colesterol HDL no sobrenadante, através de reação de ponto final. As lipoproteínas LDL e VLDL foram quantitativamente precipitadas com ácido fosfotúngstico $1,5 \mathrm{mmol} / \mathrm{L}$ e cloreto de magnésio 54mmol/L; após a centrifugação, o colesterol HDL foi determinado no sobrenadante utilizando o sistema enzimático para colesterol descrito no item 3.5.2. As dosagem foram realizadas empregando kits da LABTEST Diagnóstica (Colesterol HDL) e (Colesterol COD-ANA) e as leituras realizadas em espectrofotômetro Beckman DU 640.

\subsubsection{Cálculos da concentração de VLDL e LDL}

O cálculo dos valores de LDL e VLDL no soro dos voluntários rurais e urbanos foi realizado utilizando a equação de Friedewald:

- VLDL Colesterol $=$ Triglicerídios $/ 5$

- $\mathrm{LDL}$ Colesterol $=$ Colesterol total $-(\mathrm{HDL}+\mathrm{VLDL})$

\subsection{TRATAMENTO ESTATÍSTICO DOS RESULTADOS}

Para examinar a diferença entre as médias dos valores de vitaminas $B_{6}, B_{12}$ e ácido fólico alimentar e plasmático, bem como a dos níveis plasmáticos da Hcy, TG, colesterol total, LDL, VLDL e HDL, das duas populações urbana e rural foi utilizado o teste t de student para amostras não pareadas. 
A correlação entre quaisquer duas variáveis foi computada através de: Correlação de Pearson. Quando a correlação encontrada era significativa ( $\rho \leq$ 0.05) realizou-se uma análise de regressão uni-multivariada. Toda a análise estatística foi realizada utilizando o software SPSS( Statastical Package for Social Sciences) 8,0. 
RESULTADOS

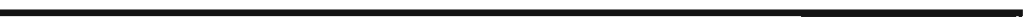




\section{RESULTADOS}

\subsection{INGESTÃO VITAMÍNICA}

A média dos valores individuais, o desvio padrão (DP), o erro padrão da média (EPM) e os valores de $p$ obtidos na comparação entre as duas populações das vitaminas $B_{6}, B_{12}$ e ácido fólico, ingeridos pelas duas populações urbana e rural, estão apresentados no anexo V. Pode-se observar nesta tabela que há diferença significativa no consumo de vitaminas $\mathrm{B}_{6}$ e ácido fólico entre as duas populações.

A figura 5 mostra a ingestão medida das vitaminas $B_{6}$ e $B_{12}$ e ácido fólico pelas duas populações e os respectivos valores da RDA. As duas populações ingerem quantidades da vitamina $\mathrm{B}_{12}$ de acordo com a recomendada, o mesmo não ocorrendo com a ingestão de ácido fólico, que se encontra bem abaixo do RDA em ambas as populações. Em relação à vitamina $\mathrm{B}_{6}$, a ingestão da mesma pela população urbana observa o RDA, o que não ocorre com a população da zona rural. Quando os dois grupos populacionais são comparados entre si, observamos que a ingestão de vitamina $B_{6}$ e ácido fólico são significativamente mais baixos na população rural que na urbana (figura 4 b e c).

Figura 5. Ingestão diária das vitaminas $\mathrm{B}_{6}(\mathrm{a}), \mathrm{B}_{12}$ (b) e ácido fólico (c), na população da zona $U$ (urbana) e $R$ (rural) e os respectivos valores da RDA.

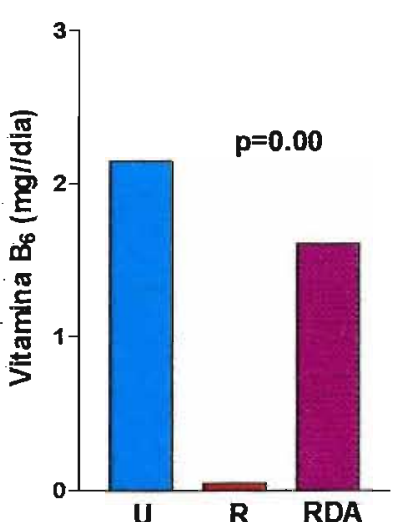

(a)

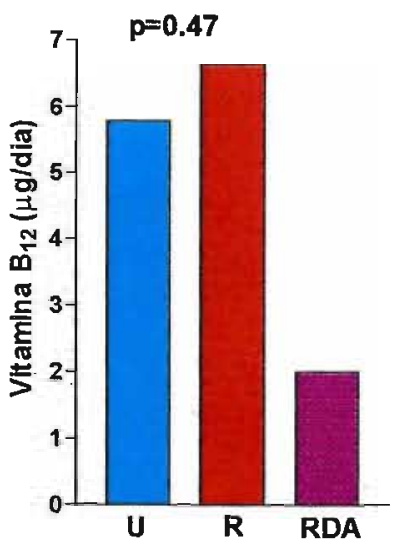

(b)

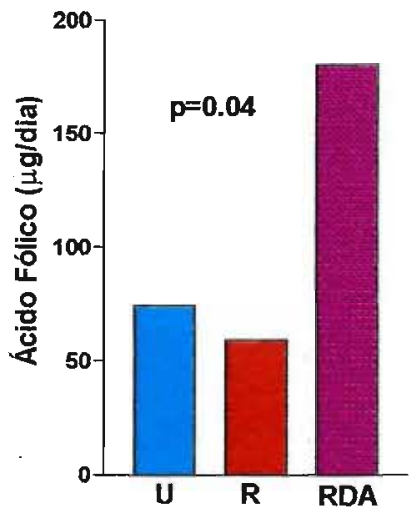

(C) 


\subsection{PARÂMETROS PLASMÁTICOS E SÉRICOS}

Os níveis plasmáticos médios das vitaminas $B_{6}$ e $B_{12}$, ácido fólico, Hcy, assim como os valores séricos de TG, colesterol total, VLDL, LDL e HDL encontrados na população rural e urbana estão apresentados no anexo VI. A população urbana apresenta níveis de vitamina $B_{6} e$ ácido fólico maiores $e$ estatisticamente significativos que a população rural (figura 6 a e b). 0 mesmo não ocorre em relação a vitamina $B_{12}$, que é igual nas duas populações (figura 6 c).

Por outro lado, os valores de Hcy encontrados na população urbana são menores que os da população rural $(p<0.002)$ (figura7). ). Os niveis de Hcy no sexo masculino e feminino da população total (urbana e rural) mostra que o sexo masculino apresenta níveis maiores que o sexo feminino $(p<0.005)$ (figura $7 a)$. Não há diferença significativa no níveis de Hcy entre homens urbanos e rurais $(p=0.12)$ (figura $7 b)$, mas a diferença entre as duas populações pode ser observada para o sexo feminino $(p=0.027)$ (figura $7 c)$. Os níveis plasmáticos de Hcy dos sexos feminino e masculino se encontram no anexo VII. Quanto a idade, os voluntários foram agrupados em: voluntários com idade de 30 a 40 anos, 41 a 50 anos e 51 a 60 anos. Não foi verificada nenhuma diferença significativa nos níveis de Hcy nestes três grupos de idade.

O perfil lipídico das duas populações são bastante diferentes. Os niveis de TG são mais altos na população rural que na urbana $(p<0.000)$ (figura 8a) e de colesterol total apresenta um perfil inverso, mais alto na população urbana que na rural $(p<0.000)$ (figura $8 b$ ). Diferenças estatisticamente significativas são encontradas também para os niveis de LDL(maior na população 
urbana; $p<0.000$ ) e VLDL (maior na população rural; $p=0.000$ ) (figura $8 \mathrm{c}, \mathrm{d}$,). os níveis de HDL é igual nas duas populações (figura 8 e).

Figura 6. Médias dos níveis plasmáticos das vitaminas $B_{6}(a)$ e $B_{12}(b)$ e ácido fólico (c), nas populações das zonas urbana (U) e rural $(R)$.

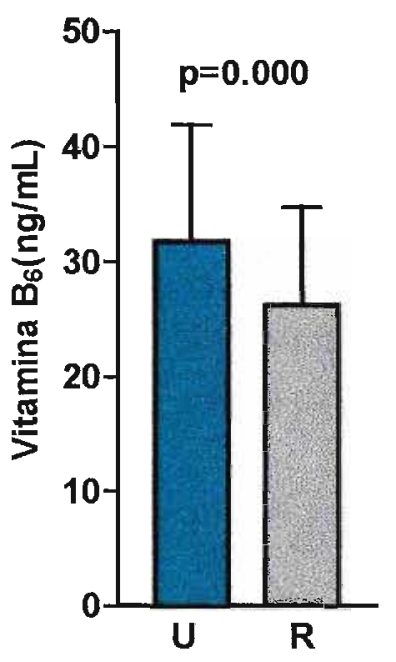

(a)

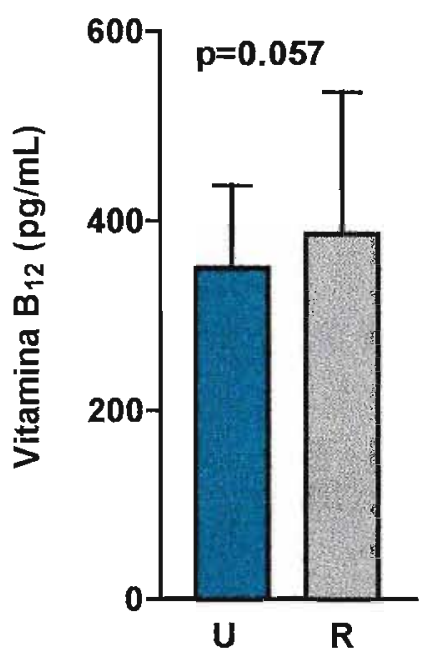

(b)

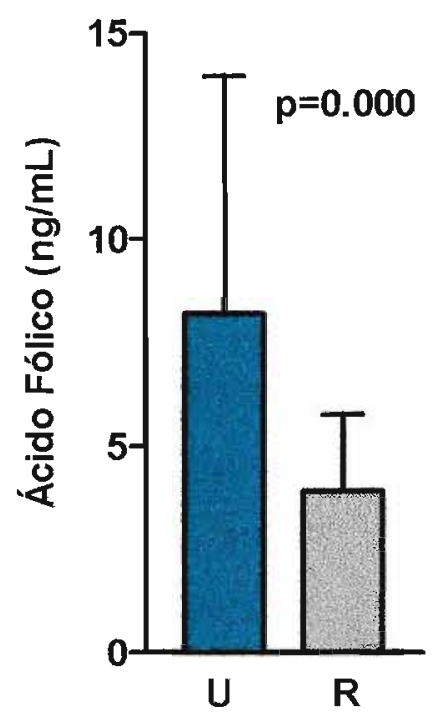

(c)

Figura 7. Níveis plasmáticos de homocisteina nas duas populações, urbana (U) e rural $(\mathrm{R})$.

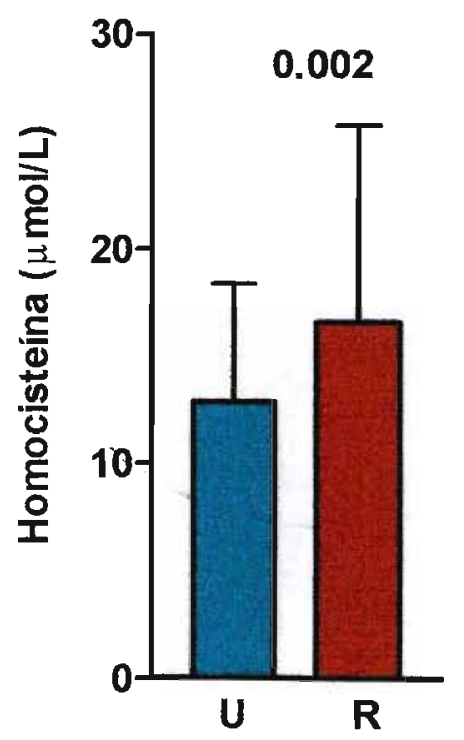


Figura 7a. Níveis plasmáticos de homocisteína no sexo masculino $(M)$ e feminino $(F)$ da população total (urbana e rural).

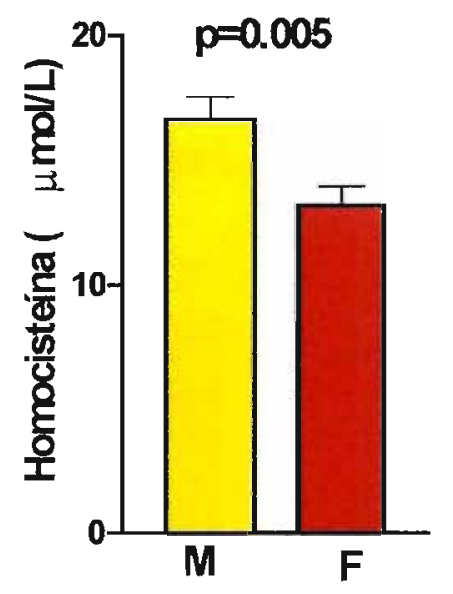

Figura $7 b$. Níveis plasmáticos de homocisteína no sexo masculino das duas populações, urbana $(U)$ e rural $(R)$.

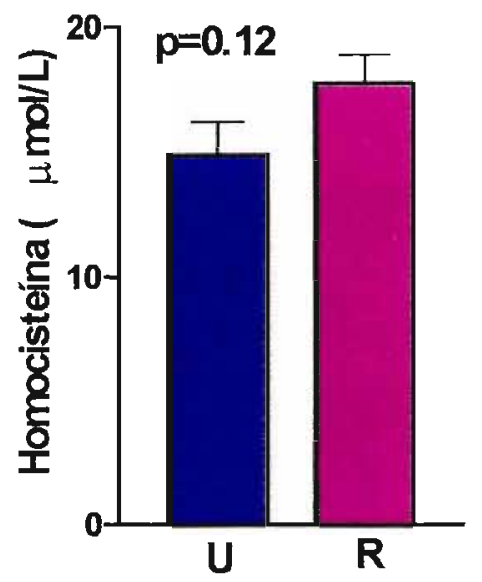

Figura 7c. Niveis plasmáticos de homocisteína no sexo feminino das duas populações, urbana (U) e rural (R).

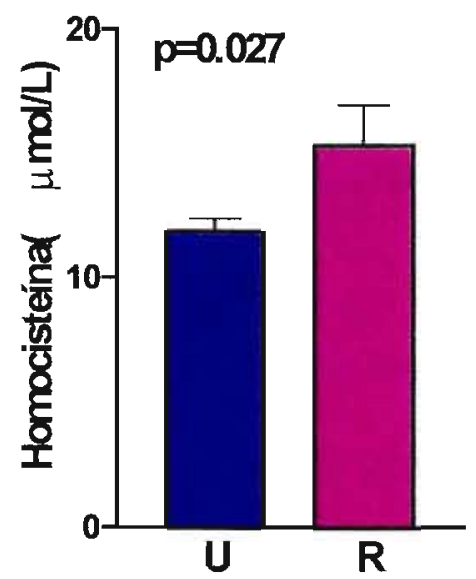


Figura 8. Níveis séricos dos lipídios TG (a), colesterol total (b), VLDL (c), LDL(d) e $H D L(e)$ nas populações das regiões urbana $(U)$ e rural $(R)$.

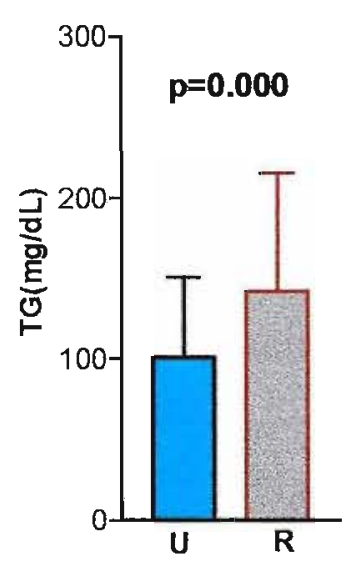

(a)

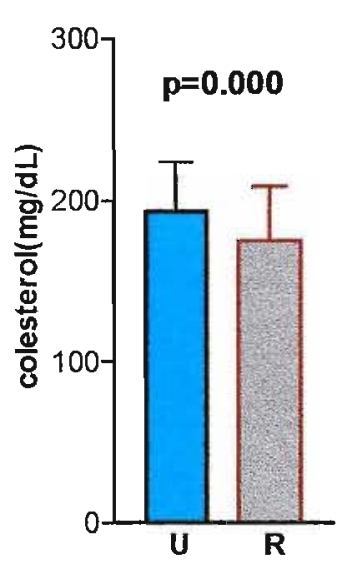

(b)

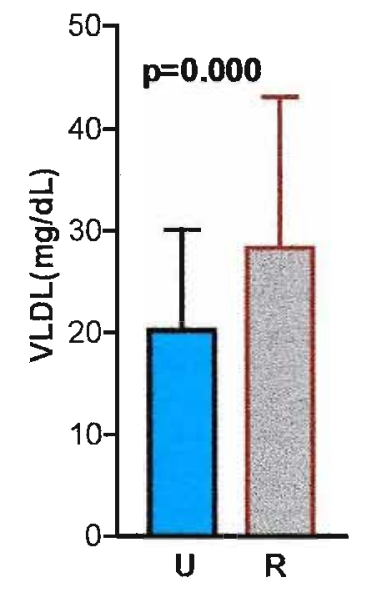

(c)

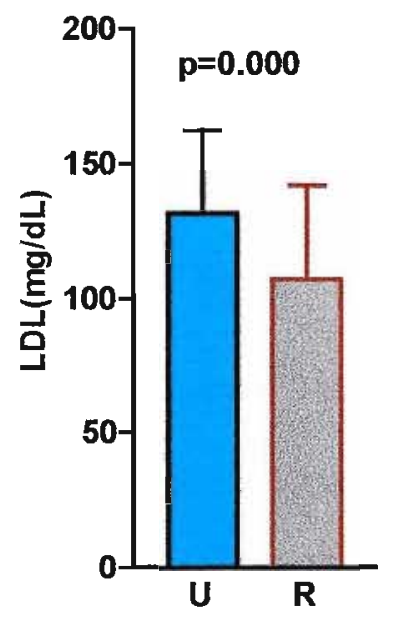

(d)

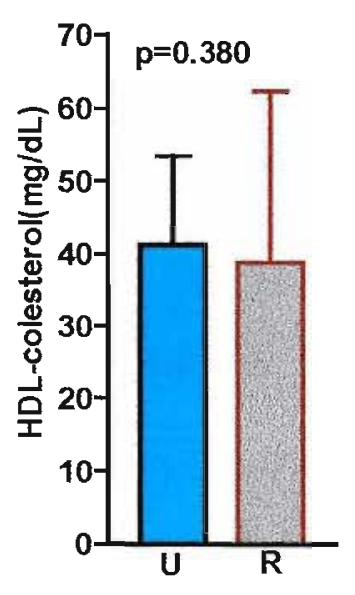

(e)

\subsection{CORRELAÇÃO ENTRE A INGESTÃO E OS NIVEÍS PLASMÁTICOS DAS} VITAMINAS

O coeficiente de correlação de Pearson, assim como os níveis de significância, obtidos entre quantidade de vitaminas ingeridas e seus níveis 
plasmáticos estão apresentados na tabela 2. Não foram observados correlações significativas entre os parâmetros mencionados.

Tabela 2. Correlação entre a ingestão e os niveis plasmáticos das vitaminas na população urbana $(n=85)$, rural $(n=86)$ e população total $(n=171)$.

\begin{tabular}{c|c|c|c|c}
\hline Parâmetros estudados & & Urbano & Rural & Total \\
\hline \multirow{2}{*}{ Vitamina $\mathrm{B}_{6}$} & $\mathrm{r}$ & 0.024 & 0.024 & 0.102 \\
\cline { 2 - 5 } & $p$ & 0.831 & 0.883 & 0.189 \\
\hline \multirow{2}{*}{ Vitamina $\mathrm{B}_{12}$} & $\mathrm{r}$ & 0.167 & 0.058 & 0.103 \\
\cline { 2 - 5 } & $p$ & 0.320 & 0.593 & 0.183 \\
\hline \multirow{2}{*}{ Acido fólico } & $\mathrm{r}$ & 0.151 & 0.058 & 0.001 \\
\cline { 2 - 5 } & $p$ & 0.206 & 0.629 & 0.376 \\
\hline
\end{tabular}

\subsection{CORRELAÇÕES ENTRE OS NÍVEIS VITAMINAS, HCY E LIPÍDIOS}

O coeficiente de correlação de Pearson, obtido entre Hcy e todos os parâmetros plasmáticos (vitamina $B_{6}$ e ácido fólico) e séricos (vitamina $B_{12}, T G$, colesterol total, VLDL, LDL e HDL) juntamente com o nível de significância $p$, estão descritos nas tabelas 3 e 4 , para populações urbana (U) e rural (R), respectivamente. A tabela 5 contém os coeficientes de correlação de Pearson das duas populações ( $U$ e R) juntas, com uma totalidade de 171 indivíduos, sendo 85 da zona U e 86 da zona R.

A população urbana, rural e totalidade de indivíduos apresentam uma correlação negativa estatisticamente significativa para a vitamina $B_{12}$ e ácido fólico $(p=0.000)$. Por outro lado, observa-se uma correlação positiva $(p=0.000)$ para vitamina $B_{6}$. Em relação ao perfil lipídico não foi encontrada nenhuma correlação estatisticamente significativa com os parâmetros estudados 
Tabela 3. Correlação entre os niveis plasmáticos das vitaminas $B_{6}$ e folato, bem como níveis séricos de $B_{12}, T G$, colesterol, VLDL, LDL e HDL, com os níveis plasmáticos de homocisteina na população urbana. (Número de indivíduos $=85$ )

\begin{tabular}{|c|c|c|}
\hline \multirow{2}{*}{\multicolumn{2}{|c|}{$\begin{array}{l}\text { Constituintes } \\
\text { Plasmáticos }\end{array}$}} & \multirow{3}{*}{$\begin{array}{c}\text { Hcy no Plasma } \\
\text { Pearson } \\
0,411\end{array}$} \\
\hline & & \\
\hline \multirow{2}{*}{$\mathrm{B}_{6}$} & $r$ & \\
\hline & $p$ & 0,000 \\
\hline \multirow{2}{*}{$\mathrm{B}_{12}$} & $r$ & $-0,437$ \\
\hline & $p$ & 0,000 \\
\hline \multirow{2}{*}{ Folato } & r & $-0,375$ \\
\hline & $p$ & 0,001 \\
\hline \multirow{2}{*}{ Triglicerídios } & $r$ & 0,047 \\
\hline & $p$ & 0,668 \\
\hline \multirow{2}{*}{ Colesterol } & $r$ & $-0,017$ \\
\hline & $p$ & 0,877 \\
\hline \multirow{2}{*}{ HDL } & $r$ & $-0,127$ \\
\hline & $p$ & 0,247 \\
\hline \multirow{2}{*}{ LDL } & $r$ & 0,028 \\
\hline & $p$ & 0,869 \\
\hline \multirow{2}{*}{ VLDL } & $r$ & 0,047 \\
\hline & $p$ & 0,668 \\
\hline
\end{tabular}


Tabela 4. Correlação entre os níveis das vitaminas plasmáticas $B_{6}$ e folato, níveis séricos de $B_{12}, T G$, colesterol, VLDL, LDL e HDL com os níveis plasmáticos de homocisteína na popủlação rural. (Número de indivíduos $=86$ )

\begin{tabular}{|c|c|c|}
\hline \multirow{2}{*}{\multicolumn{2}{|c|}{$\begin{array}{l}\text { Constituintes } \\
\text { plasmáticos }\end{array}$}} & \multirow{2}{*}{$\frac{\text { Hcy no Plasma }}{\text { Pearson }}$} \\
\hline & & \\
\hline \multirow{2}{*}{$\mathrm{B}_{6}$} & $r$ & 0,230 \\
\hline & $p$ & 0,033 \\
\hline \multirow{2}{*}{$\mathrm{B}_{12}$} & $r$ & $-0,319$ \\
\hline & $p$ & 0,003 \\
\hline \multirow{2}{*}{ Folato } & $r$ & $-0,343$ \\
\hline & $p$ & 0,005 \\
\hline \multirow{2}{*}{ Triglicerideos } & $r$ & 0,111 \\
\hline & $p$ & 0,311 \\
\hline \multirow{2}{*}{ Colesterol } & $r$ & 0,032 \\
\hline & $p$ & 0,772 \\
\hline \multirow{2}{*}{ HDL } & $r$ & $-0,116$ \\
\hline & $p$ & 0,286 \\
\hline \multirow{2}{*}{ LDL } & $r$ & 0,063 \\
\hline & $p$ & 0,566 \\
\hline \multirow{2}{*}{ VLDL } & $r$ & 0,111 \\
\hline & $p$ & 0,311 \\
\hline
\end{tabular}


Tabela 5. Correlação de Pearson entre os níveis das vitaminas plasmáticas $B_{6}$ e folato, bem como níveis séricos de $B_{12}, T G$, colesterol, VLDL, LDL e HDL, com os níveis plamáticos de homocisteína na população total (171 indivíduos)

\begin{tabular}{|c|c|c|}
\hline \multicolumn{2}{|c|}{$\begin{array}{l}\text { Constituintes } \\
\text { Plasmáticos }\end{array}$} & \multirow{2}{*}{$\begin{array}{c}\text { Hcy no Plasma } \\
\text { Pearson } \\
0,203\end{array}$} \\
\hline \multirow{2}{*}{$\mathrm{B}_{6}$} & $r$ & \\
\hline & $p$ & 0,008 \\
\hline \multirow{2}{*}{ Fólico } & $r$ & $-0,287$ \\
\hline & $p$ & 0,000 \\
\hline \multirow{2}{*}{$\mathrm{B}_{12}$} & $r$ & $-0,301$ \\
\hline & $p$ & 0,000 \\
\hline \multirow{2}{*}{ Triglicerideos } & $r$ & 0,159 \\
\hline & $p$ & 0,038 \\
\hline \multirow{2}{*}{ Colesterol } & $r$ & $-0,053$ \\
\hline & $p$ & 0,488 \\
\hline \multirow{2}{*}{ HDL } & $r$ & $-0,131$ \\
\hline & $p$ & 0,047 \\
\hline \multirow{2}{*}{ LDL } & $r$ & $-0,041$ \\
\hline & $p$ & 0,590 \\
\hline \multirow{2}{*}{ VLDL } & $r$ & 0,159 \\
\hline & $p$ & 0,038 \\
\hline
\end{tabular}

Uma vez encontradas correlações entre os níveis de Hcy e os das vitaminas estudados, busca-se entender qual o tipo de correlação.

Nos estudos de regressão univariável, a Hcy foi utilizada como fator dependente e as vitaminas $B_{6}, B_{12}$ e ácido fólico, como variáveis independentes. Também foi realizada a regressão multivariável para estudar o efeito de todas as 
vitaminas como fatores independentes e da Hcy como fator dependente. Os resultados da regressão univariável estão nas tabelas 6,7 e 8 , para as populações $U, R$ e população total ( $U$ e $R$ ), respectivamente.

Tabela 6. Coeficiente de regressão univariável, tendo homocisteína como a variável dependente para o grupo de dados de indivíduos urbanos.

\begin{tabular}{|c|c|c|c|}
\hline \multirow{2}{*}{$\begin{array}{c}\text { Variável } \\
\text { Independente }\end{array}$} & \multicolumn{2}{|c|}{ Coeficientes } & \multirow{2}{*}{$r^{2}$} \\
\hline & & $p$ & \\
\hline \multirow{2}{*}{$\begin{array}{l}\text { Constante } \\
\mathrm{B}_{6}\end{array}$} & 5,732 & 0,002 & \multirow{2}{*}{0,169} \\
\hline & 0,224 & 0,000 & \\
\hline \multirow[t]{2}{*}{$\begin{array}{l}\text { Constante } \\
\mathrm{B}_{12}\end{array}$} & 22,625 & 0,000 & \multirow[t]{2}{*}{0,1910} \\
\hline & $\frac{-0,048}{18,156}$ & $\begin{array}{l}0,000 \\
0,000\end{array}$ & \\
\hline $\begin{array}{l}\text { Constante } \\
\text { Ácido Fólico }\end{array}$ & $-0,213$ & 0,001 & 0,140 \\
\hline
\end{tabular}

Tabela 7. Coeficiente de regressão univariável, tendo homocisteína como a variável dependente para o grupo de dados de indivíduos rurais.

\begin{tabular}{l|c|c|c}
\hline \multirow{2}{*}{$\begin{array}{l}\text { Variável } \\
\text { Independente }\end{array}$} & \multicolumn{2}{|c|}{ Coeficientes } & \multirow{2}{*}{$\mathbf{r}^{2}$} \\
\cline { 2 - 3 } & \multicolumn{2}{|c}{$\mathbf{p}$} & \\
\hline Constante & 10,032 & 0,002 & \multirow{2}{*}{0,0530} \\
\cline { 2 - 3 } $\mathrm{B}_{6}$ & 0,249 & 0,033 & \\
\hline Constante & 24,160 & 0,000 & \multirow{2}{*}{0,102} \\
\cline { 2 - 3 } $\mathrm{B}_{12}$ & $-0,03$ & 0,003 & \\
\hline Constante & 24,765 & 0,000 & \multirow{2}{*}{0,120} \\
\cline { 2 - 3 } Ácido Fólico & $-0,317$ & 0,001 & \\
\hline
\end{tabular}

Tabela 8. Coeficientes de regressão univariável tendo homocisteína como a variável dependente do conjunto total de dados.

\begin{tabular}{l|c|c|c}
\hline \multicolumn{1}{c|}{$\begin{array}{c}\text { Variável } \\
\text { Independente }\end{array}$} & \multicolumn{2}{|c|}{ Coeficientes } & \multirow{2}{*}{$\mathbf{r}^{2}$} \\
\cline { 2 - 3 } & \multicolumn{2}{|c}{$\mathbf{p}$} & \\
\hline Constante & 10 & 0,0000 & \multirow{2}{*}{0,041} \\
\cline { 2 - 3 } $\mathrm{B}_{6}$ & 0,162 & 0,0080 & \\
\hline Constante & 21,730 & 0,0000 & \multirow{2}{*}{0,090} \\
\cline { 2 - 3 } $\mathrm{B}_{12}$ & $-0,038$ & 0,0000 & \\
\hline Constante & 20.989 & 0,0000 & \multirow{2}{*}{0,082} \\
\cline { 2 - 3 } Ácido Fólico & $-0,248$ & 0,000 & \\
\hline
\end{tabular}


As tabelas 6, 7 e 8 mostram que os níveis das vitaminas $B_{6}, B_{12}$ e de ácido fólico influenciam linearmente os níveis de Hcy, tanto quanto se estudamos duas populações urbana e rural isoladamente ou na sua totalidade.

As tabelas 9, 10 e 11 mostram os dados da regressão multivariavel tendo os níveis de Hcy como fator dependente e os das vitaminas como fatores independentes, para a população urbana, para a rural e para total de indivíduos estudados.

Os níveis de vitaminas $B_{6}, B_{12}$ e de ácido fólico em conjunto são responsáveis por $31 \%$ da variabilidade dos níveis de Hcy, tanto na população urbana (tabela 9) quanto na rural (tabela 10). Quando se considera a população inteira o percentual de variabilidade nos níveis de Hcy, influenciada pelas vitaminas, diminui a 18\%, sendo, ainda assim significativo (tabela11).

Tabela 9. Regressão multivariável de homocisteína para o conjunto de dados de indivíduos urbanos.

\begin{tabular}{l|c|c|c}
\hline & Coeficientes & $\mathbf{P}$ & \multirow{2}{*}{$\mathbf{r}^{2}$} \\
\cline { 1 - 3 } Constante & 15,141 & 0,0000 & \multirow{2}{*}{0,317} \\
\cline { 1 - 2 } $\mathrm{B}_{6}$ & 0,178 & 0,0010 & \multirow{2}{*}{$\mathrm{B}_{12}$} \\
\cline { 1 - 3 } Folato & $-0,0243$ & 0,0000 & \\
\hline
\end{tabular}

Tabela 10. Regressão multivariável de homocisteína para o conjunto de dados de indivíduos rurais.

\begin{tabular}{l|c|c|c}
\hline & Coeficientes & $\mathbf{P}$ & $\mathbf{r}^{2}$ \\
\hline Constantes & 19,068 & 0,0000 & \multirow{2}{*}{0,310} \\
\cline { 1 - 2 } $\mathrm{B}_{6}$ & 0,234 & 0,168 & \multirow{2}{*}{$0,0,014$} \\
\cline { 1 - 2 } $\mathrm{B}_{12}$ & $-0,019$ & 0,029 & \\
\hline Folato & $-0,289$ & 0,029 & \\
\hline
\end{tabular}


Tabela 11. Regressão multivariável de homocisteína para o conjunto total de dados.

\begin{tabular}{l|c|c|c}
\hline & Coeficientes & $P$ & $r^{2}$ \\
\hline Constantes & 18,099 & 0,000 & \multirow{2}{*}{0,183} \\
\hline $\mathrm{B}_{6}$ & 0,158 & 0,010 & \multirow{2}{*}{0,183} \\
\cline { 1 - 3 } $\mathrm{B}_{12}$ & $-0,018$ & 0,000 & \\
\cline { 1 - 3 } Folato & $-0,219$ & 0,030 & \\
\hline
\end{tabular}

\subsection{DISTRIBUIÇÃO DOS FATORES DE RISCO ENTRE AS DUAS SUB- POPULAÇÕES ESTUDADAS}

Considerando o fato que a Hcy é considerado como fator de risco independente para DCV, assim como a LDL-colesterol, procurou-se identificar entre os dois grupos populacionais a prevalência de um deles. Ambos grupos foram divididos conforme o quadro 2 .

Quadro 2. Critérios para divisão dos grupos populacionais

1. Homocisteína $<14 \mu \mathrm{mol} / \mathrm{L}$ e $\mathrm{LDL}<130 \mathrm{mg} / \mathrm{dL} \quad(3,38 \mathrm{mmol} / \mathrm{L})$

2. Homocisteína $<14 \mu \mathrm{mol} / \mathrm{L}$ e $L D L>130 \mathrm{mg} / \mathrm{dL}(3,38 \mathrm{mmol} / \mathrm{L})$

3. Homocisteina $>14 \mu \mathrm{mol} / \mathrm{L}$ e $L D L<130 \mathrm{mg} / \mathrm{dL}(3,38 \mathrm{mmol} / \mathrm{L})$

4. Homocisteína $>14 \mu \mathrm{mol} / \mathrm{L}$ e $\mathrm{LDL}>130 \mathrm{mg} / \mathrm{dL}(3,38 \mathrm{mmol} / \mathrm{L})$

1. Nenhum fator de risco

2. Um fator de risco: LDL

3. Um fator de risco: Homocisteina

4. Dois fatores de risco: LDL e Homocisteína 
Figura 9. Distribuição dos fatores de risco nas populações estudada
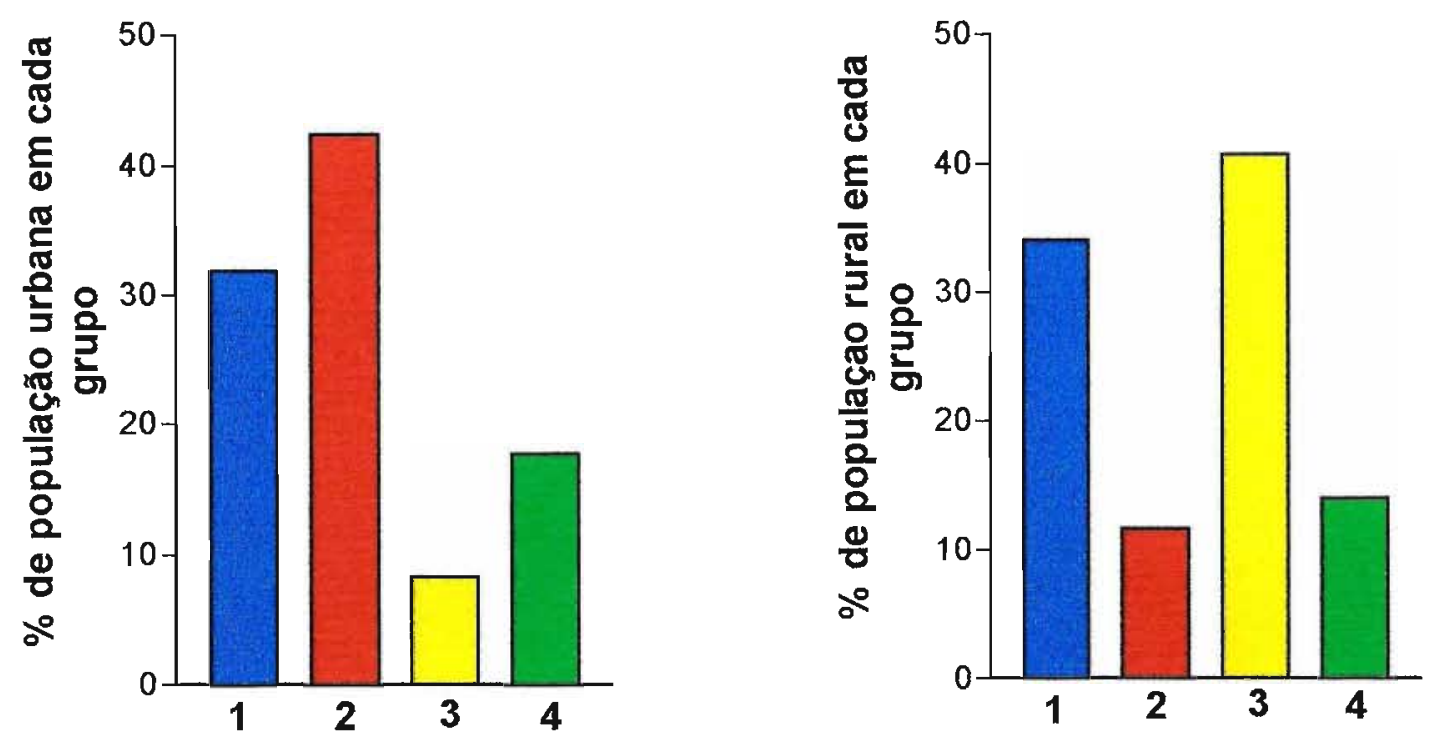

A figura 9 mostra que o fator de risco prevalecente na população urbana é o nível de LDL. Já na população rural maior porcentagem de população apresenta Hcy como fator de risco para a doença cardiovascular. 
DISCUSSÃO 


\section{DISCUSSÃO}

\subsection{RISCO DE DOENÇA CARDIOVASCULAR E A INFLUENCIA DE METABOLISMO DA HOMOCISTEINA}

O risco de DCV está relacionado a um grande número de fatores, dentre os quais as dislipidemias (HOEG, 1997 e CASTELLI, 1996). Neste sentido, existem fortes evidências que apontam para os níveis elevados de Hcy como um fator independente de risco cardiovascular (STAMPFER e cols., 1992), estando associado não apenas ao infarto do miocárdio, mas também ao acidente vascular cerebral e às doenças vasculares periféricas (WELCH \& LOSCALZO, 1998 e GRAHAM e cols., 1992).

Vários fatores influenciam o metabolismo da Hcy, dentre os quais o hábito alimentar, onde o consumo reduzido de vitaminas $B_{6}, B_{12}$ e de ácido fólico interfere no processo de remetilação e transsulfuração da Hcy. SELHUB e cols. (1993) estudaram, em 1160 indivíduos do Framingham Heart Study, com idade entre 67 e 96 anos, o consumo diário das vitaminas $B_{6}, B_{12}$ e ácido fólico, utilizando inquérito alimentar, e constataram uma correlação inversa entre o consumo das vitaminas e os niveis de Hcy. O estudo também deixou evidente que a relação entre o consumo de vitaminas e os níveis plasmáticos de Hcy não é linear.

GENEST (1993) estudou 584 Canadenses de origem francesa, de ambos os sexos, com idade média de 38 anos, constatando a existência de níveis elevados de Hcy nos indivíduos com menor consumo das vitaminas $B_{6}, B_{12}$ e, em especial, de ácido fólico.

Vários autores sugerem que os níveis plasmáticos de Hcy são modulados pela dieta, principalmente pelo consumo das vitaminas envolvidas no 
metabolismo de Hcy. Em 1999, EIKELBOOM e cols. fizeram uma revisão dos estudos epidemiológicos associando os níveis de Hcy e o risco de DCV, e constataram que os niveis plasmáticos moderadamente elevados de Hcy são prevalentes na população em geral, estando, também, associados ao consumo diário das vitaminas $\mathrm{B}_{6}, \mathrm{~B}_{12}$ e ácido fólico.

O consumo dessas vitaminas está intimamente relacionado aos hábitos alimentares, os quais variam em função da região, educação, nível social e outros. Neste sentido, o nosso trabalho objetivou estudar o consumo das vitaminas $B_{6}, B_{12}$ e ácido fólico em indivíduos de residência urbanos (U) e rural (R) a quantidade por eles ingerida das vitaminas, seus niveis plasmáticos, assim como os níveis sericos de Hcy e lipídeos e a correlação entre estes parâmetros.

Analisando os dados do inquérito alimentar, apresentados no anexo $V$ e na figura 4, verificamos que a ingestão de vitaminas $B_{6}$ e ácido fólico é significativamente maior na população urbana que a na população rural. Vitamina $B_{6}: p=0,0001$ e ácido fólico: $p=0,0054$. Quanto à ingestão de vitamina $B_{12}$, não há diferença significativa entre as duas populações estudadas (figura 5) .

Neste sentido, BROEKMANS e cols. (2000) submeteram 47 voluntários, entre homens e mulheres, a duas dietas distintas, uma delas contendo $500 \mathrm{~g} / \mathrm{dia}$ de frutas e verduras e a outra, $100 \mathrm{~g} / \mathrm{dia}$ de frutas e verduras,

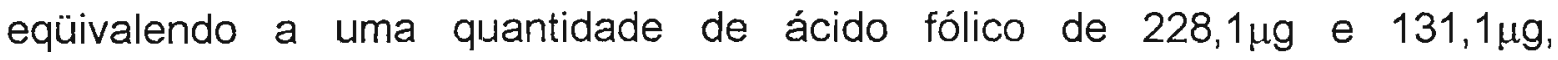
respectivamente. Realizada a análise dos níveis de Hcy plasmática, os autores verificaram que o grupo que consumiu maior quantidade de frutas e verduras apresentava $11 \%$ menos de Hcy plasmática.

De forma semelhante, RIDDEL e cols. (2000), trabalhando com 65 indivíduos, com idade entre 31 e 71 anos, submetidos a dietas contendo 
alimentos ricos em ácido fólico e cereais fortificados com ácido fólico, obtiveram resultados similares aos descritos no parágrafo anterior.

Confrontando a média de consumo das vitaminas $B_{6}, B_{12}$ e ácido fólịco com os valores de RDA (figura 5) verificamos que a população urbana apresenta média de consumo das vitaminas $B_{6}$ e $B_{12}$ acima da RDA, enquanto que o consumo de ácido fólico encontra-se abaixo da RDA. Quanto à população rural, verificamos que apenas o consumo de vitamina $B_{12}$ atinge o valor da RDA.

Comparando o consumo de vitaminas entre as populações urbana e rural (figura 5), verificamos que a população urbana consome $25 \%$ mais de ácido fólico que a população rural. Em relação a vitamina $B_{6} \circ$ consumo é 4 vezes superior ao da população rural. O inverso ocorre em relação à vitamina $\mathrm{B}_{12}$, onde a média de consumo da população rural é $15 \%$ maior do que a média da população urbana.

Ao longo da aplicação e análise do inquérito alimentar, foi possível constatar que, em média, a população rural prefere consumir alimentos de origem animal e carboidratos derivados da mandioca e do arroz, ao invés de legumes e verduras. O menosprezo pelo consumo de verduras, legumes e frutas encontra-se associado a uma desinformação dietética da importância das vitaminas e oligoelementos, junto a uma valorização do consumo de alimentos de origem animal, como símbolo de poder aquisitivo. Já a população urbana encontra-se mais esclarecida quanto ao valor nutritivo dos alimentos e seu impacto sobre a saúde, ainda que esteja mais sugestionada ao consumo de alimentos do tipo "Fast Food".

Analisando os dados em relação ao sexo na população total, notamos que o sexo masculino apresenta uma concentração de Hcy $26 \%$ maior 
que o sexo feminino, com valores de Hcy plasmáticos de $16,63 \mu \mathrm{mol} / \mathrm{L}$ e $13,20 \mu \mathrm{mol} / \mathrm{L}$, respectivamente. Estes dados estão de acordo com JACOBSEN e col, (1994) e LUSSIER-CACAN e cols, (1996), que mostram que homens apresentam níveis de Hcy $25 \%$ maiores que mulheres antes de menopausa. Os níveis de Hcy do sexo masculino e feminino da população rural foram de $17.70 \mu \mathrm{mol} / \mathrm{Le} 15.28 \mu \mathrm{mol} / \mathrm{L}$, respectivamente. Estes níveis de Hcy são maiores que os da população urbana, que são $14.87 \mu \mathrm{mol} / \mathrm{L}$ e $11.81 \mu \mathrm{mol} / \mathrm{L}$ no sexo masculino e feminino, respectivamente.

Analisando os dados referentes à Hcy plasmática, encontramos

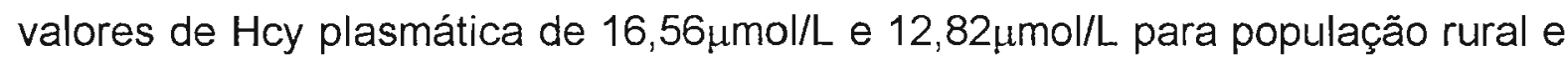
urbana, respectivamente. De acordo com os resultados obtidos do inquérito alimentar, a população urbana consome mais ácido fólico e $B_{6}$ do que a população rural, o que resulta níveis de Hcy $29 \%$ menores do que os da população rural. Estes resultados estão de acordo com as observações de outros autores (BROEKMANS e cols., 2000; RIDDEL e cols., 2000).

DeROSE e cols. (2000) trabalhando com 40 voluntários submetidos a um programa de vida vegetariana, junto ao American Lifestyle Center in Sulphur, Oklahoma, dosaram a Hcy plasmática durante o período do programa e uma semana após seu término. Os indivíduos que apresentaram Hcy acima de $9,5 \mu \mathrm{mol} / \mathrm{L}$ antes do programa de vida vegetariana tiveram redução de $19 \%$, comparado ao grupo de indivíduos com Hcy abaixo de $9,5 \mu \mathrm{mol} / \mathrm{L}$, os quais tiveram redução de apenas $8 \%$.

Ainda na linha dietética, APPEL e cols. (2000) trabalharam com 118 indivíduos, submetendo-os a 3 tipos de dietas: 1) dieta controle tipicamente americana; 2) dieta controle enriquecida com frutas e verduras e 3) dieta 
combinada contendo frutas, verduras e produtos de laticínios, incluindo também peixe, grãos integrais, nozes e conteúdo reduzido de gorduras, carnes vermelhas e doces. A dieta foi mantida ao longo de 8 semanas, tempo após o qual foram determinados os níveis plasmáticos de Hcy. A população que recebeu a dieta combinada apresentou uma redução acentuada dos níveis de Hcy. Os autores sugerem que a redução da Hcy plasmática, decorrente da dieta combinada, confere uma redução do risco cardiovascular de 7 a 9\%, quando comparado aos consumidores da dieta tipicamente americana.

Estudando o efeito da vitamina $B_{12}$ da dieta sobre os níveis plasmáticos de Hcy, HERMANN e cols. (2001) e CHAMBERS e cols. (2000) trabalhando com indivíduos não vegetarianos $e$ indivíduos restritamente vegetarianos, concluíram que a deficiência de vitaminaB ${ }_{12}$, encontrada basicamente em alimentos de origem animal, poderia estar contribuindo para a hiperhomocisteinemia observada na população de indivíduos estritamente vegetarianos.

O efeito da dieta sobre os níveis de vitamina $B_{12}$ no sangue também foi estudado por KRAJCOVICOVA-KUDLACKOVA e cols. (2000 a e b) que constataram que $78 \%$ dos indivíduos submetidos a dietas restritamente vegetarianas e $36 \%$ dos indivíduos lacto-vegetarianos, mas nenhum dos individuos onivoros, apresentavam baixos níveis de vitamina $\mathrm{B}_{12}$ no sangue.

Analisando os dados relativos a ingesta vitaminica e os niveis plasmáticos (tabela 2), nota-se que a correlação não é estatisticamente significativa, o que corrobora com os dados de DeBREE (2001). O qual indica em seu programa de educação nutricional que preconiza um maior consumo de frutas, verduras e legumes, objetivando atingir, pelo menos, 200 $\mu \mathrm{g} / \mathrm{dia}$ 
(453nmoles/dia) de ácido fólico. No entanto, deve-se considerar que o ácido fólico contido nos alimentos está na forma derivada de poliglutamato, os quais são hidrolisados a monoglutamato no intestino delgado, antes de sua absorção. Logo, a biodisponibilidade de ácido fólico nos aljmentos é menor do que a biodisponibilidade da suplementação vitamínica. A biodisponibilidade do ácido fólico nos alimentos é de 50\% (BROUWER e cols., 1999) podendo ainda sofrer alterações com o cozimento, onde há perda de 50 a 95\%. O mesmo não ocorre com a vitamina $B_{12}$ e vitamina $B_{6}$. Estas modificações alimentares poderiam alterar os níveis de ácido fólico nos indivíduos sadios, como mostra o trabalho de BROUWER e cols. (1999) onde indivíduos suplementados com ácido fólico e indivíduos consumindo alimentos ricos em ácido fólico apresentam níveis plasmáticos de ácido fólico aumentados, após de duas semanas.

A suplementação vitamínica mostra-se ideal em casos particulares, como indivíduos com mais de 50 anos, os quais apresentam má absorção de nutrientes com freqüência de 10 a 30\%. O trabalho de KOEHLER e cols. (2001) realizado com 278 idosos, mostra que a resposta nos niveis de Hcy, associada ao consumo de folato nos alimentos, é comparável à resposta dos suplementados com vitaminas.

A importância do ácido fólico pode ser explicada por seu papel no metabolismo da Hcy. O ácido fólico, na forma de 5 metilTHF, é cosubstrato no processo de remetilação da Hcy em metionina. Em contraste, as vitaminas $B_{12} e$ $\mathrm{B}_{6}$ servem como cofatores das enzimas na transsulfuração e remetilação, não sendo usadas durante a degradação; logo elas não são, freqüentemente, fatores limitantes e, por isso, os níveis de vitaminas $B_{12}$ e $B_{6}$ não apresentam tanta 
influência sobre os niveis plasmáticos de Hcy (DURAND e cols., 2001; DeBREE e cols., 2001).

Em nosso estudo, foi possível verificar que, tanto o consumo, como os níveis plasmáticos de ácido fólico, são menores na população rural, comparada à população urbana, resultando em maiores níveis plasmáticos de Hcy. Isto nos leva a considerar interessante uma educação alimentar nesta população da zona rural, já que foi concluído por vários pesquisadores que uma redução de $3 \mu \mathrm{mol} / \mathrm{L}$ de Hcy reduziria em aproximadamente, 30 a $40 \%$ o risco para DCV.

A população da zona rural não conhece os fatores de risco para DCV e muito menos a influência das vitaminas na saúde. Esta população não sabe sequer o que é vitamina, de onde ela vem e porque é necessário seu consumo. Apesar de terem a disponibilidade de legumes e verduras, não sabem que estes são excelentes fontes de vitaminas como ácido folico e vitamina $B_{6}$. $A$ idéia geral é a de que comer alimento protéico, de origem animal, é suficiente para saúde. Parece também, interessante futuramente verificar a incidência de DCV nesta população e a influência de uma suplementação vitamínica sobre os níveis plasmáticos de Hcy.

NALLAMOTHU e cols. (2000) analisaram os efeitos econômicos de terapêutica visando diminuir Hcy plasmática. O estudo conclui que a diminuição dos níveis de Hcy com suplementação de ácido fólico e vitamina $B_{12}$ resulta em um benefício substancial a um custo razoável. Dentre as conclusões, encontra-se que a dosagem da Hcy plasmática, seguida do tratamento pela suplementação, apresenta um custo menor do que um tratamento com suplementação universal. 
Discussão

Desde a publicação dos trabalhos de WILCKEN (1976), mais de 100 estudos epidemiológicos foram levados a efeito, evidenciando a relação entre os níveis moderados de Hcy e o aumento do risco para DCV. Neste caso, as concentrações plasmáticas de Hcy são influenciadas por diversos fatores, dentre eles o fator nutricional, envolvendo as vitaminas $B_{6}, B_{12}$ e ácido fólico, os quais afetam o metabolismo de Hcy. A correlação negativa entre os níveis plasmáticos de ácido fólico e vitamina $\mathrm{B}_{12}$ com os níveis plasmáticos de Hcy foi demonstrada inicialmente por KANG e cols. (1987), STABLER e cols. (1988), MANSON \& MILLER (1992) e UBBINK e cols. (1993).

PANCHARUNITI e cols. (1994) estudaram a influência dos níveis de ácido fólico e vitamina $B_{12}$ em individuos com DCV e indivíduos sadios, evidenciando a correlação negativa existente entre os níveis plasmáticos de Hcy e de ácido fólico, bem como em relação à vitamina $B_{12}$. Também, ficou, evidente que a influência do ácido fólico sobre o risco de doença cardiovascular, determinada pelos níveis de Hcy, é maior do que a da vitamina $\mathrm{B}_{12}$ plasmática, provavelmente devido ao fato da população em geral apresentar níveis mais baixos de ácido fólico do que de vitamina $\mathrm{B}_{12}$. O aumento de $\mathrm{Hcy}$, decorrente de baixas concentrações de ácido fólico e vitamina $B_{12}$, tem sido estimado em 12,5 $\eta \mathrm{mol} / \mathrm{L}$ e $225 \mathrm{pmol} / \mathrm{L}$ para ácido fólico e vitamina $\mathrm{B}_{12}$, respectivamente. Os autores ainda relatam que $50 \%$ dos individuos sadios apresentavam níveis de folato menores do que $12,5 \mathrm{nmol} / \mathrm{L}$ e somente $13 \%$ mostram concentrações de vitamina $\mathrm{B}_{12}$ abaixo de $225 \mathrm{pmol} / \mathrm{L}$.

O limite mínimo de ácido fólico no sangue de indivíduos em jejum, considerado aceitável nos EUA, é de $6,8 \eta \mathrm{mol} / \mathrm{L}$, sendo que $15 \%$ dos americanos apresentam níveis abaixo desse limite. Em contraste, a Organização Mundial da 
Saúde (OMS) estabelece o valor de $13,6 \eta \mathrm{mol} / \mathrm{L}$ como limite para a concentração plasmática de ácido fólico. Por esse critério, $50 \%$ dos americanos estariam abaixo do limite mínimo aceitável em relação ao ácido fólico. Os dados de PANCHARUNTI e cols. (1994) e MORRISON e cols. (1996) concordam com o preconizado pela OMS, mostraram que os indivíduos com niveis plasmáticos de ácido fólico abaixo do limite mínimo da OMS, mas acima de 6,8 $\eta \mathrm{mol} / \mathrm{L}$, apresentavam níveis aumentados de Hcy e maior risco de DCV.

Os trabalhos de JACOB e cols. (1994) e DARLEY e cols. (1995) estudaram a relação entre niveis plasmáticos de Hcy e níveis plasmáticos das vitaminas $B_{6}, B_{12}$ e ácido fólico, concluindo que os níveis de Hcy são influenciados pelo níveis das vitaminas e que a Hcy constitui um fator de risco para DCV. Também ficou evidente que o ácido fólico afeta os níveis de Hcy, sugerindo até que o aumento dos níveis de Hcy poderia ser utilizado como marcador da deficiência de ácido fólico.

Em 1995, BOUSHEY e cols. concluíram que o aumento do consumo de ácido fólico (aproximadamente 200 $\mu \mathrm{g} / \mathrm{dia}$ ) reduz em $4 \mu \mathrm{mol} / \mathrm{L}$ os níveis plasmáticos de Hcy. Assumindo que a redução dos niveis de Hcy reduz o risco de DCV, calculou=se o efeito do consumo de ácido fólico (alimentos, suplementação e grão fortificados) sobre os niveis de Hcy, chegando-se à conclusão que esta medida poderia evitar entre 13.500 a 50.000 mortes ao ano por DCV. Adicionalmente, os autores concluíram que o aumento de $5 \mu \mathrm{mol}$ de Hcy no plasma corresponde a um risco de DCV equivalente ao aumento de $0,5 \mathrm{mmol} / \mathrm{L}$ de colesterol no soro.

Analisando os niveis plasmáticos das vitaminas $B_{6}, B_{12}$ e ácido fólico, bem como os níveis plasmáticos encontrados na Hcy da população urbana 
estudada, sumarizados no anexo $\mathrm{VI}$, verificamos que os individuos urbanos apresentam valores plasmáticos de vitaminas dentro da faixa dos valores de referências (anexo VII) o mesmo ocorrendo com os valores das vitaminas na população rurạl. Entretanto, enquanto a média de ácido fólico dos indivíduos da região rural é de $8,84 \mathrm{nmol} / \mathrm{L}$ ou seja, abaixo do limite recomendado pela Organização Mundial de Saúde, o mesmo não ocorrendo com os indivíduos da população urbana, que apresentam 18,62nmol/L de ácido fólico plasmáticos. Comparando os resultados do presente estudo com os dados da literatura citados, podemos concluir que a população rural estaria mais sujeita a apresentar um aumento de Hcy no sangue.

A diferença entre os níveis de ácido fólico no sangue pode ser explicada pelos dados obtidos do inquérito alimentar, onde se demonstrou que a população rural consome cerca de $25 \%$ menos ácido fólico do que a população urbana, embora ambas as populações tenha ingesta desta vitamina abaixo do RDA

Analisando os dados das tabelas 3,4 e 5, observamos que há uma correlação negativa, e significante, entre os niveis plasmáticos de Hcy e o da vitamina $B_{12}$ e de ácido fólico, tanto na população urbana, quanto na rural e no conjunto total de indivíduos estudados.

Analisando os dados obtidos da população urbana e da população total, verifica-se que há uma correlação negativa $(-0,43)$ entre os níveis de vitamina $\mathrm{B}_{12}$ e Hcy e de -0.37 entre os de ácido fólico e Hcy (tabela 3 ). Essas correlações estão de acordo com os dados da literatura, onde a correlação varia de $-0,19$ a $-0,60$ para o ácido fólico, e $-0,14$ a $-0,55$ para a vitamina $B_{12}$ (PANCHARUNITI e cols.,1994; JACOB e cols.,1994; DARELY e cols., 1995; 
CHAMBERS e cols., 2000; APPEL e cols.,2000; KOEHLER e cols. 2001 e De BREE e cols., 2001).

O fato da população urbana apresentar maior correlação negativa entre vitamina $B_{12}$ e $\mathrm{Hcy}$ do que entre ácido fólico e Hcy, pode ser explicado segundo trabalho de QUINLIVAN e cols (2002) onde os autores relatam uma forte correlação entre os níveis plasmaticos $(6,3 \mu \mathrm{g} / \mathrm{L}$ ou $6,3 \mathrm{ng} / \mathrm{mL}$ ou 2.77nmoles/L) ácido fólico e Hcy no período de pré suplementação, a qual, após a suplemantação apresentava fraca correlação. Por outro lado, os autores verificaram que após suplementação com ácido fólico acima de $400 \mu \mathrm{g} / \mathrm{dia}$ (907nmoles/dia), a correlação negativa decorrente do impacto da vitamina $\mathrm{B}_{12}$ nos níveis plasmaticos de Hcy, torna -se mais evidente. No presente estudo não é possivel identificar qual das vitaminas, se o ácido fólico ou vitamina $B_{12}$, é responsável pelo níveis de altos de Hcy, na população urbana.

A relação entre o ácido fólico e os níveis plasmáticos da Hcy descreve uma curva com declínio inicial acentuado, tornando-se gradualmente um platô nos níveis mais altos de ácido fólico (SELHUB e cols., 1993; NYGARD e cols., 1998 e 1999). Este fato implica em que o aumento do consumo de ácido fólico teria o maior efeito nos níveis plasmáticos de Hcy quando o consumo for menor que 200 $\mathrm{g} / \mathrm{dia}$ (453nmoles/dia). Adicionalmente, os niveis plasmáticos de Hcy decrescem com o consumo de ácido fólico acima de $200 \mu \mathrm{g} / \mathrm{dia}$ (453nmoles/dia) (DEBREE e cols., 1997). Neste sentido, DEBREE e cols (2001), concluíram que o ácido fólico plasmatico dentro de uma certa faixa, teria grande efeito sobre os níveis plasmáticos de Hcy, além de outros fatores como álcool e fumo. 
KEEBLER e cols. (2001) concluem que a terapia com vitaminas, particularmente o ácido fólico, reduz os níveis de Hcy, além de melhorar a função endotelial, que é um dos marcadores de doença cardiovascular. A idade é um dos fatores que influencia de forma importante os niveis plasmáticos de Hcy, sendo que esta influência pode estar relacionada à queda nos níveis plasmáticos de ácido fólico por consumo diário inadequado (CHRITODOULAKES e cols., 2001).

A correlação entre a deficiência no consumo diário de ácido fólico e o aumento da $\mathrm{Hcy}$, associado ao aumento de volume corpuscular médio das hemácias e a doença arterial periférica, foi observada por MUELLER e cols. (2001). SANCHEZ e cols. (2001) concluíram em seu trabalho que a hiperhomocisteinemia na gravidez é fator de risco para pré-eclampsia e que baixos níveis plasmáticos de ácido fólico aumentam o risco de pré-eclampsia. VERHAAR e cols. (2002) mencionam que o ácido fólico além da sua influência na redução dos níveis de Hcy, apresenta efeitos benéficos como antioxidante e por sua interação com a enzima óxido nítrico sintase.

Dados recentes da literatura (KLEE, 2000; McKAY e cols., 2000; PAGÁN e cols., 2001; DeBREE e cols., 2001; KOEHLER e cols., 2001) mostram que, das vitaminas envolvidas no metabolismo de homocisteína, a que tem maior efeito como determinante nutricional nos níveis plasmáticos de Hcy é o ácido fólico.

Não só os trabalhos recentes, mas o trabalho de BOUSHELY e cols. (1995) estima a influência de ácido fólico nos niveis plasmáticos de Hcy, sugerindo que o consumo diário de $350 \mu \mathrm{g} / \mathrm{dia}$ para homens e $280 \mu \mathrm{g} / \mathrm{dia}$ para mulheres poderia, potencialmente, evitar 30500 e 19000 mortes por DCV em 
homens e mulheres, respectivamente $150 \%$ dos individuos cardiopatas apresentam niveis altos de Hcy, além de $10 \%$ dos indivíduos normais e $30 \%$ dos indivíduos idosos).

Em relação à vitamina $B_{6}$, apesar da população rural apresentar consumo menor que o RDA, os dados do nosso estudo não mostraram nenhuma alteração nos níveis plasmáticos de Hcy como conseqüência do consumo mais baixo.

A análise relativa dos dados deste trabalho em relação aos níveis plasmáticos de vitamina $B_{6}$, mostra uma correlação positiva com a à Hcy plasmática, contradizendo os dados de ROBINSON (1998) que cita a deficiência de vitamina $B_{6}$ como sendo mais freqüente em pacientes com DCV do que nos controles $\mathrm{O}$ autor também cita a deficiência de piridoxina, em animais, como causadora de lesão vascular. Neste sentido, os trabalhos de RYAN e cols.(1993) FRANKEN e cols. (1994) LAKSHMI e cols. (1998) e MANSOOR e cols. (1999) demonstraram que a vitamina $B_{6}$ é capaz de promover redução significativa dos niveis plasmáticos de Hcy.

Suplementando a dieta com as vitaminas $\mathrm{B}_{6}, \mathrm{~B}_{12}$ e ácido fólico, isoladamente, ao longo de 6 semanas, UBBINK e cols. (1994) notaram que a suplementação de vitamina $B_{6}(10 \mathrm{mg} / \mathrm{dia})$ não tinha nenhum efeito sobre concentração de Hcy, enquanto que a suplementação com ácido fólico $(0,65 \mathrm{mg} / \mathrm{dia})$ e vitamina $\mathrm{B}_{12}$ reduziram em $41,7 \%$ e $14,8 \%$ os níveis de Hcy, respectivamente. O mesmo é comentado na revisão feita por WOODSIDE e cols., em 1997.

O estudo da correlação entre os dados de suplementação vitamínica, os níveis plasmáticos das vitaminas e a Hcy, apresentado por McKAY 
e cols. (2000) deixa claro que a correlação entre a vitamina $B_{6}$ e Hcy é positiva, e que a vitamina $B_{6}$ não exerce efeito sobre os níveis de Hcy. Já McKINLEY e cols. (2001) concluíram que a vitamina $B_{6}$ reduz efetivamente os niveis plasmáticos de Hcy em jejum, quando administrada em doses muito baixas a indivíduos sem DCV e sugere que, os programas de tratamento e prevenção de hiperhomocisteinemia, devam incluir a vitamina $B_{6}$. Apesar da vitamina $B_{6}$ ter sido utilizada no tratamento de homocistinúria causada pela deficiência de $\beta$ cistationina sintetase, seu papel da na prevenção ou tratamento de hiperhomocisteinemia moderada ainda não está claro.

Os valores das regressões univariáveis entre Hcy e vitaminas $B_{6} e$ $B_{12}$ e ácido fólico (Tabelas 6,7 e 8) mostram, na população urbana, que os niveis de Hcy são direta e inversamente proporcionais aos niveis de vitamina $\mathrm{B}_{12}$ e ácido fólico. O mesmo se observa em relação à população rural e ao total de indivíduos estudados. Na população urbana, os níveis de ácido fólico são responsáveis por $19 \%$ da variabilidade dos níveis de $\mathrm{Hcy}$, enquanto os níveis de vitamina $\mathrm{B}_{12}$ são responsáveis por $14 \%$. Na população rural, os níveis de ácido fólico e de vitamina $\mathrm{B}_{12}$ são responsáveis, respectivamente, por $12 \%$ e $10 \%$ da variabilidade de homocisteína, enquanto que na totalidade dos indivíduos, essas porcentagens são de $8 \%$ e $9 \%$.

Os valores das regressões multivariáveis entre Hcy e vitaminas $B_{6}$, $B_{12}$ e ácido fólico (Tabelas 9,10 e 11) mostram que os níveis das vitaminas em conjunto são responsáveis por $31 \%$ da variabilidade dos níveis de Hcy, tanto na população urbana como na rural. $\mathrm{Na}$ totalidade dos indivíduos estudados, o percentual de variabilidade dos niveis de Hcy influenciado pelas vitaminas diminui para $18 \%$. 
Nossos dados corroboram os dados obtidos por RIDDEL e cols. (2000) que calcularam, na população por eles estudada, uma influência de 14\% do ácido fólico e $9 \%$ da vitamina $\mathrm{B}_{12}$, na variabilidade dos níveis plasmáticos de Hcy. A influência destas vitaminas em conjunto foi de 19\%. Já PANCHARUNTI e cols. (1996) observaram uma influência maior destas vitaminas na variabilidade da Hcy, chegando a 54\%. A discrepância entre estes valores pode ser devida à inclusão de indivíduos potencialmente deficientes em ácido fólico e/ou vitamina $\mathrm{B}_{12}$, indivíduos com Hcy elevado ou outras variáveis adicionais.

Como acima mencionado, a influência das vitaminas na variabilidade dos niveis de Hcy é apenas parcial, havendo outros fatores que podem participar deste processo. Um exemplo é a atividade da MTHFR, considerada um dos fatores determinantes na concentração de Hcy em reposta à intervenção com ácido fólico. Nos indivíduos homozigotos, esta mutação autossômica recessiva provoca hiperhomocisteinemia moderada, que pode ser tratada com suplemento de ácido fólico (JACQUES e cols., 1996; FOHR e cols, 2002). A deficiência de ácido fólico pode ser parcialmente responsável pela expressão do genótipo da MTHFR termolábil e a hiperhomocisteinemia observada nestes pacientes com mutação para MTHFR raramente resulta de uma maior necessidade de ácido fólico (MOLLOY e cols., 1997). BOUSHEY (1995) confirma que a redução de $3 \mu \mathrm{mol} / \mathrm{L}$ de tHcy pode reduzir 30 a $40 \%$ o risco de doenças coronarianas isquêmicas.

\subsection{LDL-COLESTEROL, HOMOCISTEÍNA E A DOENÇA CARDIOVASCULAR}

Os dados do nosso estudo em relação ao níveis de lipídios séricos (TG, colesterol total, LDL, VLDL e HDL) estão no anexo VI. A comparação dos 
níveis dos lipidios entre as populações urbanas e rurais está nas figuras 7 a, b, c e 8 a, b. As duas amostras apresentam diferença significativa entre os níveis de colesterol total, triglicerédios, LDL e VLDL, os mesmos não tendo sido visto para HDL. Adicionalmente, os niveis de LDL colesterol da população urbana está acima dos niveis desejáveis $3,38 \mathrm{mmol} / \mathrm{L}(130 \mathrm{mg} / \mathrm{dL})$, na prevenção das doenças cardio vasculares.

Níveis elevados de Hcy estão relacionados com inúmeros processos envolvidos na aterosclerose ou trombose. Os possíveis mecanismos envolvem: disfunção endotelial, endotélio e coagulação, vasodilatação dependente do endotélio, efeito citotóxico a células endoteliais, inflamação, estresse oxidativo, agregação plaquetária, células de músculo liso e colágeno e lipoperoxidação (WU e cols., 1994).

A Hcy pode levar à lesão arterial pela promoção da oxidação da LDL. Vários estudos concluem que aminoácidos contendo sulfato, como na Hcy, podem causar a oxidação da LDL, na presença de metais de transição, como cobre e ferro. Desta forma, a Hcy pode agir iniciando a oxidação da LDL, etapa necessária para o desenvolvimento da aterosclerose. Adicionalmente, OLSZEWSKI e McCULLY (1991) sugerem que o excesso de Hcy seria transportado pela LDL em indivíduos hipercolesterolêmicos. Este excesso de Hcy estaria ligado à apolipoproteína B, causando modificação na LDL. A LDL, modificada ou oxidada, é reconhecida por receptores scavenger de macrófagos na parede arterial, levando a formação de células espumosas.

No fígado, altas concentrações de Hcy podem levar à formação de Hcy-tiolactona, que extravasa para a circulação e também promove a oxidação da LDL, levando ao desenvolvimento da arterosclerose (McCULLY e cols., 1990; 
OLSZEWSKI e McCULLY, 1993; HIRANO e cols., 1994; McCULLY, 1996; VOUTILAINEN e cols., 1999).

PANCHARUNTI e cols. (1994) e WU e cols. (1994) mostram que há correlação significativa e positiva entre os níveis de Hcy, LDL e o risco da doença cardiovascular. Estes estudos sugerem que indivíduos com niveis normais de LDL estariam desenvolvendo patologias cardiovasculares através do efeito da Hcy sobre a oxidação da LDL.

Por outro lado, BLOM e cols. (1992) e DUDMAN e cols. (1993) concluíram que altos niveis plasmáticos de Hcy não estão associados com aumento de peroxidação de lipidios. BLOM e cols. (1995) informam que a susceptibilidade da LDL à oxidação catalisada pelo cobre é igual em pacientes com hiperhomocisteinemia e indivíduos normais. Os autores ainda discutem o fato de que os estudos in vitro, que falam de lesão endotelial, mediada pela formação de espécies reativas de oxigênio, pela ação da Hcy, utilizam concentrações extremamente altas de Hcy na forma reduzida. A Hcy. reduzida é a forma livre, que corresponde a menos que $1 \%$ da Hcy sangüínea, não sendo, portanto, compatível com as condições fisiológicas normais. Estes argumentos levam à conclusão de que o risco de doença cardiovascular na hiperhomocisteinemia não, seria devido ao aumento na peroxidação de lipídeos causado por Homocisteína.

HALVERSON e cols. (1996) que estudaram o efeito da homocisteína sobre a oxidação da LDL, utilizando três sistemas diferentes de oxidação, concluíram que a Hcy, em concentrações correspondentes às encontradas em indivíduos com homocistinúria, pode na verdade seqüestrar radicais livres, agindo, desta forma, como proteção à oxidação da LDL. Assim, um aumento severo de Hcy plasmática levaria um estado antioxidante. O mesmo foi concluído 
por ANDERSON e cols. (1995), UELAND e cols. (1996) e BOURDON E BLACHE (2001).

FERGUSON e cols. (1999) sugerem que a reação entre Hcytiolactona e LDL geraria um aduto Hcy-LDL, que seria mais resistente à modificação oxidativa do que a LDL nativa; isto explicaria o porquê da menor susceptibilidade da LDL à oxidação em indivíduos com homocistinúria.

A análise dos dados das populações urbana, rural e na população total, neste trabalho, mostrou não haver correlação significativa entre os niveis de Hcy e LDL, como mostram as tabelas 3 a 5 . Nota-se que os níveis de LDL são maiores na população urbana do que na rural; esta mesma população urbana de Hcy menores que os da população rural. Devido às divergências nos estudos sobre o efeito da Hcy sobre LDL, modelos experimentais com diferentes niveis de Hcy são ainda necessários para a avaliação da capacidade da Hcy de promover a oxidação LDL. HALVERSON e cols. (1996) explicam que as diferenças nos dados da literatura entre Hcy moderada e severa podem ser decorrentes do efeito ambivalente dos aminotióis (pró e antioxidante).

Por outro lado, foi observada uma correlação negativa e significativa indicada pela correlação de Pearson, entre os niveis de Hcy e HDL, na população total (tabelas 3.4 e 5), o mesmo não é observado em relação à populaçăo urbana e rural. Este achado é corroborado pelos os dados de CHRISTENSEN e cols., (1999) onde os níveis de Hcy e HDL, apoA-I, fumo e ácido fólico de 107 indivíduos com infarto de miocárdio foram correlacionados. Especula-se sobre a correlação inversa entre Hcy e HDL, uma vez que estudos com camundongos transgênicos indicaram que altos níveis de apoA-I devem inibir a oxidação da LDL e baixos níveis de apoA-I facilitariam a oxidação da LDL 
(KWITEROVICH,1996). Logo, a redução de apoA-I deve afetar o efeito oxidativo da hiperhomocisteinemia.

A distribuição dos fatores de risco, $L D L>130 \mathrm{mg} / \mathrm{dL}(3,38 \mathrm{mmol} / \mathrm{L})$ e Hcy $>14 \mu \mathrm{mol} / \mathrm{L}$, foi calculado nas duas populações (figura 9). No caso de Hcy utilizou-se o valor de $14 \mu \mathrm{mol} / \mathrm{L}$ como aquele considerado normal na população. $\mathrm{O}$ uso deste valor como corte foi baseado em vários trabalhos, como o de SUPERKO (1995), os quais concluíram que indivíduos com níveis de Hcy acima de $14 \mu \mathrm{mol} / \mathrm{L}$ teriam maiores chances de ter estenose da artéria carótida. PETRl e cols. (1996) definem que concentrações plasmáticas de Hcy acima de $14 \mu \mathrm{mol} / \mathrm{L}$ são considerados como hiperhomocisteinemia. GRAHAM e cols. (1997) estimam que o limite para definir hiperhomocisteinemia, relacionada com risco para a doença cardiovascular, seria de $12 \mu \mathrm{mol} / \mathrm{L}$. Niveis de homocisteina plasmáticas acima de $14 \mu \mathrm{mol} / \mathrm{L}$ foram utilizados como hiperhomocisteinemia para o tratamento com vitaminas em pacientes com placas na carótida (HACKAM e cols., 2000). BISSONNETTE e cols. (2001), verificou aumento de Hcy plasmatica depois tratamento com fenofibrato, definem hiperhomocisteinemia como níveis plasmáticos de Hcy acima de $14 \mu \mathrm{mol} / \mathrm{L}$.

A divisão das duas populações estudadas quanto a presença de um ou dois fatores de risco mostra que na população urbana o fator predominante (42\%) é o nível de LDL colesterol > 130mg/dL (3.38mmol/L). Já na população rural níveis de homocisteína acima de $14 \mu \mathrm{mol} / \mathrm{L}$ são encontrados em $40.7 \%$ dos individuos. Os dois fatores de risco, a hiperhomocisteinemia e os niveis elevados de LDL-colesterol, estão presentes, em conjunto, em cerca de 17\% da população, seja ela urbana ou rural. Tanto a educação alimentar, como a suplementação vitamínica, poderiam reduzir o risco de doença cardiovascular relacionado à 
homocisteína, já que se sabe que a suplementação com ácido fólico (0,65mg/dia) leva a uma redução de $41,7 \%$ nos niveis plasmáticos de Hcy (WOODSIDE, 1996).

O American Heart Association em 1999 (MALINOW e cols, 1999) sugere que os indivíduos com histórico familiar de aterosclerose devem ter níveis de Homocisteina abaixo de $10 \mu \mathrm{mol} / \mathrm{L}$ e que o tratamento inicial deve ser a alteração alimentar; caso essa medida não seja suficiente, deve-se então intervir

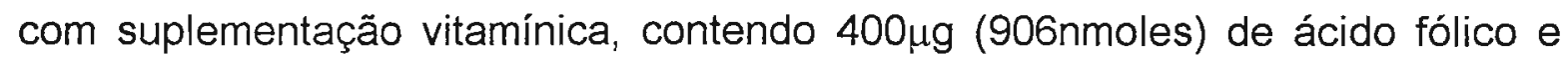
$2 m g$ de $B_{6}$ e $6 \mu g$ de $B_{12}$.

SCHAERFER (2002) conclui que, na prevenção da doença cardio vascular, não é suficiente a recomendação sobre o consumo limitado de gorduras, óleos, alimentos de origem animal, laticínios e ovos isoladamente; deve-se também a orientação a população em relação ao aumento de consumo de verduras, frutas e grãos onde encontramos grande quantidade de vitaminas do complexo B.

O presente estudo mostra diferenças importantes na dieta dos duas populações estudadas, que se refletem na presença de um maior percentual de individuos da zona urbana com niveis de LDL-colesterol acima dos recomendados e, nos residentes da zona rural a prevalência de indivíduos com homocisteína acima de $14 \mu \mathrm{mol} / \mathrm{L}$, esta último devido ao consumo inadequado de vitaminas do complexo B. 


\section{CONCLUSÕES}

1. O consumo da vitamina $B_{6}$ e de ácido fólico é superior na população urbana do que na rural.

2. Os niveis plasmáticos de Hcy na população rural são mais altos do que os da população urbana. Os valores desta última se encontram na faixa dos limites referenciais normais, enquanto a rural se encaixa na faixa de hiperhomocisteinemia moderada. Este fato foi atribuido ao menor consumo de ácido fólico neste grupo.

3. Os níveis plasmáticos das vitaminas $B_{6}, B_{12}$ e ácido fólico, em conjunto, são responsáveis por $31 \%$ da variabilidade nos níveis plasmáticos de Hcy, tanto na população rural como na urbana.

4. Os niveis séricos de LDL-colesterol, na população rural, são menores do que os da população urbana e se encontram na faixa de referência desejável. Em contrapartida, a média dos níveis da população urbana se encontra no limite superior do nível de referência desejável, caracterizando-se como faixa de risco para DCV.

5. O fator de risco de DCV predominante na população rural é a hiperhomocisteinemia, enquanto que na população urbana é o nível sérico elevado de LDL-colesterol. 


\section{REFERÊNCIAS BIBLIOGRÁFICAS}




\section{REFERÊNCIAS BIBLIOGRÁFICAS}

ALFTHAN, G., PEKKANEN, J., JAUHIAINEN, M. et al. - Relation of serum homocysteine and lipoprotein(a) concentrations to atherosclerotic disease in a prospective Finnish population based study. Atherosclerosis, 106:9-19, 1994.

ALPERT JE AND FAVA M. Nutrition and depression: the role of folate. Nutr. Rev. $55(5) 145-149,1997$

ANDERSON JL, MUHLESTEIN JB, HORNE BD, CARLQUIST JF, BAIR TL, MADSEN TE, AND PEARSON RR. - Plasma homocysteinepredicts mortality independently of traditional risk factors andC-reactive protein in patients with angiographically defined coronary artery disease. Circulation 102:1227-1232. 2000

ANDERSSON A, BRATTSTRÖM L, ISRAELSSON B, ISAKSSON A, HAMFELTA, AND HULTBERG B. - Plasma homocysteine before and after methionine loading with regard to age, gender, and menopausal status. Eur. J. Clin. Invest. 22:79-87., 1992

ANDERSSON A, LINDGREN A, AND HULTBERG B. - Effect of thiol oxidation and thiol export from erythrocytes on deter-mination of redox status of homocysteine and other thiols in plasma from healthy subjects and patients with cerebral infarction. Clin. Chem. 41:361-366., 1995

APPEL LJ, MILLER ER III, JEE SH, STOLZENBERG-SOLOMON R, LIN PH, ERLINGER T, NADEAU MR, AND SELHUB J. - Effect of dietary patterns on serum homocysteine: Results of a randomized, controlled feeding study. Circulation 102:852-857.,2000 
ARAKI A, SAKO Y. - Determination for free and total homocysteine in human plasma by high-performance liquid chromatography with fluorescence detection. J. Chrom. 122:43-52, 1987.

ARNESEN, E., REFSUM,H., BONAA, KH., UELAND P.M., FORDE ${ }^{\circ} \mathrm{H}_{\text {, }}$ NORDREHAU J.E - Serum total homocysteine and cornary heart disease. Int. J. Epidemiol. 24:704-9, 1995.

BATES CJ, PENTIEVA KD, MATHEWS N, MacDONALD - A simple sensitive reproducible assay for pyridoxal phosphate in human plasma. Clin. Chim. Act. 280:101-111, 1999.

BELEZ S, FRICKEL C, WOLFROM C, NAU H, HENZE G. . - High performance liquid chromatographic determination of methotrexate, 7-hydromethotrexate, 5-methyltetrahydrofolic acid and folinic acid in serum and cerebrospinal fluid. J. Chrom. B. 661:109-118, 1994.

BELLAMY MF, MCDOWELL IFW, RAMSEY MW, BROWNLEE M, BONES C, NEWCOMBE RG, AND LEWIS MJ. - Hyperhomo-cysteinemia after an oral methionine load acutely impairs endothelial function in healthy adults. Circulation 98:1848-1852., 1998.

BELLAMY MF, MCDOWELL IFW, RAMSEY MW, BROWNLEE M, NEWCOMBE RG, AND LEWIS MJ. - Oral folate enhances endothelial function in hyperhomocysteinaemic subjects. Eur. J. Clin. Invest. 29:659-662., 1999.

BENTE HALVORSEN, INGBORG BRUDE, CHRISTIAN A. DREVON, JETTE NYSOM, LEIV OSE, ERLING N.CHRISTIANSEN AND MARIT S. NENSETER. - Effect of homocysteine on copper ion-catalyzed, azo compund-initiated and mononuclear cell-mediated oxidative modification of low density lipoprotein. J. Lipid Res. 37, 1591-1600, 1996. 
BERG VAN EM M, JONG SC, DEVILLE $W$ et al -. Variability of fasting and postmethionine plasma homocysteine levels in normo-and hyperhomocusteinaemic indivuals. Neth. J. Med. 55: 29-38, 1999.

BERG M, BOERS GHJ. - Homocustinuria: what about mild hyperhomocysteinaemia? Postgard. Med. J. 72: 513-518, 1996.

BESCOND A, AUGIER T, CHAREYRE C, GARCON D, HORNEBECK W, AND CHARPIOT P. - Influence of homocysteine on matrix metalloproteinase-2: Activation and activity. Biochem. Biophys. Res. Commun. 263:498-503., 1999

BETTIN KJ. . - Afood frequency questionnaire design for a low literacy population. Am. J. Clin. Nutr. 59:492-505, 1982.

BISSONNETTE R, TREACY E, ROZEN R, BOUCHER B, CHON JS, GENEST J. - Fenobibrate raises plasma homocysteine levels in the fasted and fed states. Atherosclerosis, 155:455-462, 2001.

BJORKEGREN K, SVARDSUDD K. - Serum cobalamin, folate, methylmalonic acid and total homocysteine as vitamina B12 ans folate tissue deficiency markers amongst elderly Swedes -a population -based study. J. Inter. Med. 249(5): 423-32, 2001.

BJORKE-MONSEN AL, VOLLSET SE, UELAND PM, REFSUM H. - Plasma total homocysteine, vitamin status and 5,10-methylenetetrahydrofolate reductase polymorphism in children. Neth. J. Med. 51:S50-S50, 1998.

BLEICH S., DEGNER D. - Whole blood folate, homocysteine in serum and risk of first acute myocardial infarction., Atherosclerosis, 147:317-326, 1999.

BLOCK G . - A review of validations of dietary assessment methods. Am. J. epidem. 115:492-505, 1990. 
BLOCK G, HARTMAN AM, NAUGHTON DA. . - Areduced dietary questionnaire development and validation. Epidemiology, 1:58-64, 1990/

BLOM, HJ. - Consequences of homocysteine export and oxidation in the vascular system. Semin. Thromb. Hemost. 26:227-232, 2000.

BLOM H.J., D.P.E. ENGELEN, G.H.J.BOERS, A M. STADHOUDERS, R.C.A SENGERS, R. DE ABREU, M.T.W.B. TEOPOELE-POTHOFF AND J.M.F.TRIJBELS - Lipid peroxidation in homocysteinaemia. J. Inherit. Metab. Dis. 15:419-422. 1992,

BLOM H.J., H. KLEINVELD, G.H.J.BOERS, P.N.M.DEMACKER, H.L.M.HAKLEMMERS, M.T.W.B.TEPOELE-POTOHH AND J.M.F. TRIJBELS. - Lipid perioxidation and susceptibility of low density lipoproteine in vitro oxidation in hyperhomocysteinaemia. Eur. J. Clin. Invest. 25:149-154. 1995

BOOTH GL, WANG EEL. - Preventive health care, 2000update: screening and management of hyperhomocysteinemia for the prevention of coronary artery disease events. CMAJ. 163:21-29, 2000

BOSTOM AG, GOHH RY, TSAI MY, HOPKINS-GARCIA BJ, NADEAU MR, BIANCHI LA, JACQUES PF, ROSENBERG IH, AND SELHUB J - ExcesS prevalence of fasting and postmethionine-loading hyperhomocysteinemia in stable renal transplant recipients. Arterioscler. Thromb. Vasc. Biol. 17:1894-1900., 1997

BOURDON E AND BLACHE D. - The importance of proteins in defense against oxidation. Antiox Redox Signal. Boushey CJ, Beresford SAA, Omenn GS, and Motulsky AG (1995). A quantitative assessment of plasma homocysteine as a risk factor for vascular disease. Probable benefits of increasing folic acid intakes. JAMA. 274:1049-1057, 2001. 
BRATTSTRÖM L. - Vitamins as homocysteine-lowering agents. J. Nutr. 126:1276S-1280S., 1996

BRATTSTRÖM L, LANDGREN F, ISRAELSSON B, LINDGREN A, HULTBERG B, ANDERSSON A, CUSKELLY G, MCNULTY H, STRAIN SS, MCPARTLIN J, WEIR DG, SCOTT JM, DEN HEIJER M, BROUWER IA, BLOM HJ, BOS GMJ, SPAANS A, ROSENDAAL FR, THOMAS CMG, HAAK HL, WIJERMANS PW, GERRITS WBJ, NAURATH HJ, AND JOOSTEN E .Lowering blood homocysteine with folic acid based supplements: Metaanalysis of randomised trials. Br. Med. J. 316:894-898., 1998

BROEKMANS WM, KLOPPING-KETELAARS IA, SCHUURMAN CR, VERHAGEN $H$, VAN DEN BERG $H$, KOK FJ, AND VAN POPPEL $G$ - Fruits and vegetables increase plasma carotenoids and vitamins and decrease homocysteine in humans. J. Nutr. 130:1578-1583. 2000

BROUWER IA, VAN DUSSELDORP M, WEST CE, MEYBOOM S, THOMAS CMG, DURAN M, HOF KHV, ESKES TKAB, HAUTVAST JGAJ, STEEGERS-THEUNISSEN RPM. - Dietary folate from vegetables and citrus fruit decreases plasma homocysteine concentrations in humans in a dietary controlled trail J. Nutr. 129: 1135-1139, 1999.

BOUSHEY, C.J., BERESFORD, SAA., OMENN, GS., MOTULSKY, AGA. Quatitative assessment of plasma homocusteine as a risk factor for vascular disease. JAMA. 271(13): 1049-57, 1995.

BUTZ LW, Du VIGNEAUD V. - The formation of homologue of cystine by decomposition of methionine with sulfuric acid, J. Biol. Chem. 99:135-42, 1932. 
Case records of the Massachusets General Hospital. Marked cerebral symptoms following a limp of three months'duration. New. Engl. J. Med. 209:1063-6, 1933.

CANDITO M, BEDOUCHA P, MAHAGNE MH, SCAVINI G, CHATEL M. - TOTAL. PLASMA HOMOCYSTEINE DETERMINATION BY LIQUID CHROMATOGRAPHY BEFORE AND AFTER METHIONINE LOADING. Results in cerebrovascular diseas. J. Chromat. B. 692: 213-216, 1997.

CARSON NA, NEILL DW. - Metabolic abnormalities detected in a survey of mentally backward individuals in Northern Ireland. Arch. Dis. Child. 37: 505$13,1962$.

CASTELLI WP. - Lipids risk factors and ischaemic heart disease. Atherosclerosis, 124(Suppl)S1-S9, 1996.

CATTANEO M. - Hyperhomocysteinemia, atherosclerosis and thrombosis. Thromb Haemost 81:165-176., 1999

CATTANEO M, FRANCHI $F$, ZIGHETTI ML, MARITNELLI I, ASTI D, AND MANNUCCI PM - Plasma levels of activated protein $C$ in healthy subjects and patients with previous venous thromboembolism: Relationships with plasma homocysteine levels. Arterioscler. Thromb. Vasc. Biol. 18:13711375., 1998

CHALLEM. J., DOLBY,V. - Homocysteine The Secrect Killer, The real cause of heart disease and stroke. Keats Publishing, Inc. New Canaan, Connecticut. 1997.

CHAMBERS JC, UELAND PM, OBEID AO, WRIGLEY J, REFSUM H, KOONER JS. - Improved vascular endothelial funtion after oral B vitamins ; Na effect 
mediated through reduced concentrations of free plasma homocysteine. Circulation. 102(20): 2479-83, 2000.

CHAMBERS JC, MCGREGOR A, JEAN-MARIE J, OBEID OA, AND KOONER JS - Demonstration of rapid onset vascular endothelial dysfunction after hyperhomocysteinemia: An effect reversible with vitamin C therapy. Circulation, 99:1156-1160., 1999a

CHAMBERS JC, OBEID OA, AND KOONER JS - Physiological increments in plasma homocysteine induce vascular endothelial dysfunction in normal human subjects. Arterioscler. Thromb. Vasc. Biol. 19: 2922-2927. 1999b

CHANBERS JC, OBEID AO, REFSUM H, UELAND P, HACKETT D, HOOPER J, TURNER RM, THOMPSON SG, KOONER JS. - Plasma homocysteine concentrations and risk of coronary heart disease in UK Indian Asian and European men. Lancet, 355(9203): 523-7, 2000.

CHAO CL, CHIEN KL, AND LEE YT. - Effect of short-term vitamin (folic acid, vitamins B6 and B12) administration on endothelial dysfunction induced by post-methionine load hyperhomocysteinemia. Am. J. Cardiol. 84:13591361., 1999

CHEN Z AND BANERJEE R. - Purification of soluble cytochrome b5 as a component of the reductive activation of porcine methionine synthase. J. Biol. Chem. 273: 26248-55, 1998.

CHEN N, LIU Y, GREINER CD, AND HOLTZMAN JL. - Physiologic concentrations of homocysteine inhibit the human plasma GSH peroxidase that reduces organic hydroperoxides. J. Lab. Clin. Med. 136: 58-65., 2000 CHRISTENSEN B., LANDAAS, S., STENSVOLD I., DJUROVIC ., RETTERSTOL L, RINGSTAD J, BERG K., THELLE D.S. - Whole blood folate, 
homocysteine in serum, and risk of first acute myocardial infarction.

Atherosclerosis, 147: 317-326, 1999.

CHRISTODOULAKOS G, PANOULIS C, RIZOS D, MOUSTAKARIAS T, PHOCAS

I, CREATSAD G. - Homocysteine and folate levels in post menopausal women. Maturitas 39(2):161-7, 2001.

CLARKE R, ARMINTAGE J. - Vitamin supplementes and cardiovascular risk: review of the randamized trails of homocysteine-lowering vitamin supplements. Semin. Thromb. Hemost. 26(3): 341-8, 2000.

CLARK R, KHAW KT, WOODHOUSE P et al. - Variability and determinants of plasma total homocysteine in na elderly population. Clin. Chem. 44:102-107, 1998.

CLARKE, R., DALY, L., ROBINSON, K., NAUGHTEN, E., CAHALANE, S., FOWLER, B. - Hyperhomocystinemia: an independente risk factor for vascular disease. New Engl. J. 324: 1149-55, 1991.

CONSTANT J, BLANN AD, RESPLANDY F, PARROT $F$, SEIGNEUR M, AND RENARD M - Endothelial dysfunction during acute methionine load in hyperhomocysteinaemic patients. Atherosclerosis 147: 411-413, 1999

CORWELL PE, MORGAN SL, VAUGHN WH . - Modification of a high performance liquid chromatographic method for assay of homocysteine in human plasma. J. Chrom. 617L: 136-139, 1993.

CRAVO ML, GLORIA LM, SELHUB J, NADEAU MR, CAMILO ME, RESENDE MP, CARDOSO JN, LEITAO CN, AND MIRA FC. - Hyperhomocysteinemia in chronic alcoholism: Correlation with folate, vitamin B-12, and vitamin B-6 status. Am. J. Clin. Nutr. 63:.220-224., 1996 
D'ANGELO A AND SELHUB J. - Homocysteine and thrombotic disease. Blood, $90: 1-11,1997$

DARLEY K, LUSSIER-CACAN S, SELHUB J, DAVIGNON J., LATOUR $Y$, GENEST J. - Homocysteine and coronary artery disease in French Canadian subjects: relation with vitamins B12, B6, pyridoxal phosphate, and folate. Am. J. Cardiol. 75:1107-1111, 1995.

DeBREE A, VERSCHUREN WMM, BLOM HJ, KROMHOUT D. - Association between $\mathrm{B}$ vitamins intake and plasma homocysteine concentration in the general Dutch population aged 20-65y. Am. J. Clin. Nutr., 73:1027-1033, 2001

DeBREE A, van DUSSELDORP N, BROUWER IA, van het HOF, STEEGERS RPM - Folate intake in Europe: recommended, actual and desired intake. Eur. J. Clin. Nutr. 51:643-660, 1997.

de JONG SC, STEHOUWER CD, VAN DEN BERG M, KOSTENSE PJ, ALDERS D, JAKOBS C, PALS G, AND RAUWERDA JA. - Determinants of fasting and post-methionine homocysteine levels in families predisposed to hyperhomocysteinemia and premature vascular disease. Arterioscler. Thromb. Vasc. Biol. 19:1316-1324., 1999

Den HEIJER M, BLOM HJ, GERRITS WBJ, et al. - Is hyperhomocysteinaemia a risk factor for recurrent venus thrombosis? Lancet, 345: 882-5, 1995.

Den HEIJER, M., KOSTER, T., BLOM, HJ., et al. - Hyperhomocusteinemia as a risk factor for deep-vein thrombosis. N. Engl. J. Med. 334: 759-62, 1996.

den HEIJER M, BROUWER IA, BOS GMJ, BLOM HJ, VAN DER PUT NMJ, SPAANS AP, ROSENDAAL FR, THOMAS CMG, HAAK HL, WIJERMANS PW, AND GERRITS WBJ. - Vitamin supplementation reduces blood 
homocysteine levels: A controlled trial in patients with venous thrombosis and healthy volunteers. Arterioscler. Thromb. Vasc. Biol. 18: 356-361., 1998.

DeROSE DJ, CHARLES-MARCEL ZL, JAMISON JM, MUSCAT JE, BRAMAN MA, McLANE GD, MULLEN JK. - Vegan diet-based lifestyle program rapidly lowers homocysteine levels. Preventive Med.. 30:.225-233, 2000.

DI MinNo G, DAVÌ G, MARGAGLIONE M, CIRILLO F, GRANDONE E, CIABATTONI G, CATALANO I, STRISCIUGLIO P, ANDRIA G, PATRONO C, AND MANCINI M. - Abnormally high thromboxane biosynthesis in homozygous homocystinuria. Evidence for platelet involvement and probucol-sensitive mechanism. J. Clin. Invest .92:1400-1406., 1993

DONNELLY JG, PRONOVOST C. - Evaluation of the AbbottIMx fluorescence polarization immunoassay and bio-rad enzyme immunoassay for homocysteine:Comparison with high performance liquid chromatography. Ann. Clin. Biochem. 37:194-198, 2000.

DUAN W, LADENHEIM B, CUTLER RG, KRAUMAN II, CADET JL, MATTSON MP - Dietary folate deficiency and elevated homocysteine levels endanger dopaminergic neurons in models of Parkinson's disease. J. Neurochem. $80(1): 101-110,2002$

DUDMAN NPB, HICKS C, WANG J, AND WILCKEN DEL. - Human arterial endothelial cell detachment in vitro: Its promotion by homocysteine and cysteine. Atherosclerosis 91: 77-83., 1991

DUDMAN, N.P., D.E. WILCKEN, AND R. STOCKER. - Circulating lipid hydroperoxide levels in human hyperhomocysteinemia. Relevence to development of arteriosclerosis. Arterioscler. Thromb. 13: 512-516. 1993 
DURAND P, PROST M., LOREAU N, LUSSIER-CACAN S, DENIS B. - Impaired homocysteine metbolism and Atherothrombotic disease. Lab. Invest. 81: $645-672,2001$

DURAND P, PROST M, AND BLACHE D. - Pro-thrombotic effects of a folic acid deficient diet in rat platelets and macrophages related to elevated homocysteine and decreased n-3 polyunsaturated fatty acids. Atherosclerosis, 121: 231-243, 1996

DURAND P., LUSSIER-CACAN S., AND BLACHE D. - Acute methionine loadinduced hyperhomocysteiemia enhances platelet aggregation, thromboxane biosynthesis and macrophage-derived tissue factor activity in rats. FASEB J., $11: 157-1168,1997 a$

DURAND P, PROST M, AND BLACHE D. - Folic acid deficiency enhances oral contraceptive-induced platelet hyperactivity. Arterioscler. Thromb. Vasc. Biol. 17: 1939-1946, 1997b

DURAND P, PROST M, AND BLACHE D. - Folate deficiency and cardiovascular pathologies. Clin. Chem. Lab. Med. 36: 419-429, 1998a

DURAND P, PROST M, AND BLACHE D. - Folate deficiency and cardiovascular pathology. Rev. Fr. Labo. 307: 45-54., 1998 b.

"Diet debate. Is cholesterol the culprit?" Time, august 6 page 61, 1979

EBERHARDT RT, FORGIONE MA, CAP A, LEOPOLD JA, RUDD MA, TROLLIET M, HEYDRICK S, STARK R, KLINGS ES, MOLDOVAN NI, YAGHOUBI M, GOLDSCHMIDT-CLERMONT PJ, FARBER HW, COHEN $R$, AND LOSCALZO J. - Endothelial dysfunction in a murine model of mild hyperhomocyst(e)inemia. J. Clin. Invest. 106: 483-491., 2000. 
ECK LH, WILLET WC . - Considerations in modifying semiquantitative food frequency questionnaire. J. Am. Diet. Assoc. 91(8): 970-973, 1991.

ECK LH, KLESGES RC, HANSON CL, SLAWSON D, PORTIS L, LAVASQUE ME - Measuring short-term dietary intake: development and testing of a 1week food frequency questionnaire. J. Am. Diet. Assoc. 91(8): 940-945, 1991.

EIKELBOOM JW., LONN E, GENEST J., HANKEY G, YUSUF $S$. Homocyst(e)ine and cardiovascular disease: a critical review of the epidemiologic evidence. Ann. Intern. Med. 131(5): 363-75, 1999.

FENTON WA, AND ROSENBERG LE. - Inherited disorders of cobalamin transport and metabolism. In Scriver CR, Beaudet AL, Sly WS, and Valle D, editors, The metabolic and molecular bses of inherited disease. New York, McGraw-Hill, 3129-3149, 1995.

FERGUSON E, HOGG N, ANTHOLINE WE, JOSEPH J, SINGH RJ, PARTHASARATHY S, AND KALYANARAMAN B. - Characterization of the adduct formed from the reaction between homocysteine thiolactone and lowdensity lipoprotein: Antioxidant implications. Free Radic. Biol. Med. 26: 968977., 1999.

FINKELSTEIN,JD. - Metionine metabolism in mammals, J. Nutr. Biochem. 1: 228-237, 1990 .

FINKELSTEIN,JD. - Pathways and regulation of homocysteine metabolism in mammals. Semin. Thromb. Hemost. 26(3): 219-26, 2000.

FINKELSTEIN,JD., MARTIN,JJ. - Homocysteine. Int. J. Biochem. Cell Biol. 32(4): 385-9, 2000. 
FOHR IP, PRINZ-LANGENOHL R, BRUNSTRUP A, BOHLMANN AM, NAU H, BERTHOLD HK, PIETRZIK K. -5,10-Methyleneytetrahydrofolate reductase genotype determines the plasma homocysteine-lowering effect of supplementation with 5-methyltetrahydrofolate or folic acid in healthy young women. Am. J. Clin. Nutr. 75: 275-282, 2002.

FOKKEMA RM, WEIJER JM, JANNEKE DIJCK-BROUWER DA, VAN DOORMAAL JJ, MUSKIET FAJ. - Influence of Vitamin-optimized Plasma Homocysteine Cutoff Values on the Prevalence of Hyperhomocusteinemia. Clin. Che. 47(6): 1001-1007, 2001.

FORTIN, L.J. \& GENEST, J. Jr. - Measurement of homocyst(e)ine in the prediction of arteriosclerosis. Clin. Biochem. 28(2): 155-162, 1995.

FOWLER B. - Disorders of homocysteine metabolism. J. Inher. Metab. Dis., 20: 270-85, 1997.

FRANCO RF. ARAUJO AG. GUERREIRO JF. ELION J., ZAGO MA. - Analysis of the $677 \mathrm{C} \rightarrow \mathrm{T}$ mutation of methylenetetrahydrofolate reductase gene in different ethnic groups. Thromb. Haemost. 79:119-21, 1998.

FRANKEN DG, BOERS GHJ, BLOM HJ AND TRIJBELS JMH. - Effect of various regimens of vitamin $\mathrm{B} 6$ and folic acid on mild hyperhomocysteinaemia in vascular patients. J. Inherited. Metab. Dis. 17:159-162, 1994a.

FRANKEN DG, BOERS GHJ, BLOM HJ AND TRIJBELS JMH, KLOPPENBORT PWE - Treatment of mild hyperhomocysteinemia in vascular disease patients. Arteriocler. Thromb. 14: 465-470, 1994b.

FREYBURGER G, LABROUCHE S, SASSOUST G, ROUANET F, JAVORSCHI S, AND PARROT F. - Mild hyperhomocysteinemia and hemostatic factors in 
patients with arterial vascular diseases. Thromb. Haemost. 77: 466-471., 1997.

FRONTIERA MS, STABLER SP, KOLHOUSE JF, ALLEN RH. - Regulation of methionine metabolism:Effects of nitrous oxide and excess dietary methionine. J. Nutr. Biochem. 5: 28-38, 1994.

FROSST, P., HENK,J., BLOM,R., MILOS, PHILIPPE GOYETTE, CA., SHERPHARD, ROWENA, G., MATTHEWS, GODFRIED, JH., BOERS, MARTIN DEN HEIJAR, LEO,AJK., LAMBERTPWJ., VAN DEN HEUVEL, RIMA ROZEN, - A candidate risk factor for vascular disease: A common mutation in methylenetetrahydrofolate reductse". Nature Genetics 10:11113, 1995.

FROSST P., BLOM HJ., MILOS R. et al. - Identification of a candidate genetic risk factor for vascular disease: a common mutation at the methylenetetrahydrofolate reductase locus. Nat. Genet. 10:111-3, 1995.

FRYER RH, WILSON BD, GUBLER DB, FITZGERALD LA, RODGERS GM. Homocysteine a risk factor for peremature vascular disease and thrombosis, induces tissue factor activity in endothelial cells. Arterioscler. Thromb. 13:1327-1333, 1993.

FU W, DUDMAN NP, PERRY MA, YOUNG K, AND WANG XL - Interrelations between plasma homocysteine and intracellular S-adenosylhomocysteine. Biochem. Biophys. Res. Commun 271: 47-53., 2000

FUKAGAWA NK, MARTIN JM, WURTHMANN A, PRUE AH, EBENSTEIN D, AND O'ROURKE B. - Sex-related differences in methionine metabolism and plasma homocysteine concentrations. Am. J. Clin. Nutr. 72: 22-29.,2000. 
FUSTER V. - Mechanisms leading to myocardial infarction: insights from studies of vascular biology. Circulation, 90:2126-46, 1995

GARG UC, ZHENG ZJ, FOLSAM AR et al. - Short-term and long term variability of plasma homocysteine measurement. Clin.Chem. 43: 141-5, 1997.

GENEST, JJ., McNAMARA, JR., SALEM, DN., WILSON, PWF., SCHAEFER, EJ., MALINOW, MR. - Plasma homocyst(e)ine in men with premature coronary artery disease. J. Am. Col. Cardiol.16:1114-9, 1990.

GENEST, JJ., McNAMARA, JR., UPSON,B., SALEM, DN., ORDOVAS, JM., SCHAEFER, EJ., MALINOW, MR. - Prevalence of familial hyperhomocus(e)inemia in men with premature coronary artery disease. Arterioesclerosis Thromb. 11: 1129-36, 1991.

GENEST J, LUSSIER-CACAN S, QUI S, DAVIGNON J, LATOUR Y, SELHUB J . - Homocyst(e)ine and coronary disease in French Canadians: Relationship with vitamins B12, B6, pyridoxal phosphate andd folate. Can. J. Card. 9: 81E, 1993.

GERRITSEN T, VAUGHN JG., WEISMAN HÁ. - The identification of homocysteine in the urine. Biochem. Biophys. Res. Commum. 9: 493-6, 1962.

GILFIX BM, BLANK DW, ROSENBLATT DS. - Novel reductant for determination of total plasma homocysteine. Clin. Chem. 43: 687-688, 1997.

GLUECK, C J., PETER SHAW, LANG,J.E., TARCY,T., LUANN SIEVE-SNITH, YING WANG. - Evidence that homocysteine is na independent risk factor for atherosclerosis in hyperlipidemic patients. Am. J. cardiol. 75: 132-136, 1995. 
GRAEBER JE, SLOTT JH, ULANE RE, SCHULMAN JD, STUART MJ. - Effect of homocysteine and homocystine on platelet and vascular arachidonic acid metabolism. Pediatr. Res. 16: 490-493, 1982.

GRAHAM IM, DALY LE, REFSUM HM, ROBINSON K, BRATTSTRÖM LE, UELAND PM, PALMA-REIS RJ, BOERS GHJ, SHEAHAN RG, ISRAELSSON B, UITERWAAL CS, MELEADY R, MCMASTER D, VERHOEF P, WITTEMAN J, RUBBA P, BELLET H, WAUTRECHT JC, DE VALK HW, LÚIS ACS, PARROT-ROULAUD FM, TAN KS, HIGGINS I, AND GARCON D - Plasma homocysteine as a risk factor for vascular disease. The European Concerted Action Project. JAMA, 277: 1775-1781., 1997

GRIEND R, BIESMA DH, BANGA JD. . - Hyperhomocysteinaemia as a cardiovascular risk factor: an update. The Neth. J. of Med. 56:119-130, 2000.

GUTHIKONDA S, HAYNES WG. . - Homocysteine as a novel risk factor for atherosclerosis. Curr. Opin. Cardiol. 14(4): 283-911, 199.

HACKAM DG, PETERSON JC, AND SPENCE JD. - What level of plasma homocyst(e)ine should be treated? Effects of vitamin therapy on progression of carotid atherosclerosis in patients with homocyst(e)ine levels above and below 14 micromol/L. Am. J. Hypertens. 13:105-110., 2000

HAJJAR KA. - Homocysteine-induced modulation of tissue plasminogen activator binding to its endothelial cell membrane receptor. J. Clin. Invest. 91:28732879., 1993

HAJJAR KA, MAURI L, JACOVINA AT, ZHONG FM, MIRZA UA,PADOVAN JC, AND CHAIT BT. - Tissue plasminogen activator binding to the annexin II tail 
domain. Direct modulation by homocysteine. J. Biol. Chem. 273: 99879993., 1998

HALVORSEN B, BRUDE I, DREVON CA, NYSOM J, OSE L, CHRISTIIANSEN EN, AND NENSETER MS - Effect of homocysteine on copper ioncatalyzed, azo compound-initiated, and mononuclear cell-mediated oxidative modification of low density lipoprotein. J. Lipid. Res. 37:1591-1600., 1996.

HARKER LA, ROSS R, SLICHTER SJ SCOTT CR. - Homocysteine induced arteriosclerosis. The role of endothelial cell injury and platelet response in its genesis. J.Clin. Invest. 58: 31-741., 1976.

HARPEL PC, ZHANG XX AND BORTH W. - Homocysteine and hemostasis: Pathogenetic mechanisms predisposing to thrombosis. J. Nutr. 126: 1285S1289S. 1996.

HEINECKE JW, ROSEN H, SUZUKI LA, AND CHAIT A. - The role of sulfurcontaining amino acids in superoxide production and modification of low density lipoprotein by arterial smooth muscle cells. J. Biol. Chem. 262:10098-10103.,1987

HERRMANN W, SCHORR H, PURSCHWITZ K, RASSOUL F, RICHTER V. Total homocysteine, vitamin $\mathrm{B}(12)$, and total antioxidant status in vegetarians. Clin. Chem. 47 (6): 1094-1101, 2001.

HIRANO K, OGIHARA T, MIKI M, YASUDA H, TAMAI H, KAWAMURA N, AND MINO M. - Homocysteine induces iron-catalyzed lipid peroxidation of lowdensity lipoprotein that is prevented by alpha-tocopherol. Free Radic. Res. 21: $267-276 ., 1994$

HOEG JM - Evaluating coronary heart disease risk: tiles in the mosaic. JAMA, $277: 1387-1390,1997$. 
HOLVEN K.B., HOLM T., AUKRUST P., CHRISTENSEN R., KJEKSHUS J., ANDREASSEN A K., CULLESTAD L., HAGVE T.A, SVILAAS A, OSE L., NENSETER M.S. - Effect of folic acid treatment on endothelium-dependent vascodilation and nitric oxide-derived end products in hyperhomocysteinemic subjects. Am. J. Med. 110(7): 536-542, 2001

HURST JW. - Doenças de vazos sanguineas. Ed. Guanabara Koogan, 1990. IINGEBORG A, DUSSELDORP MV., WEST C.E., MEYBOOM S., THOMAS C.M.G., DURAN M., HOF K.H., ESKES T.K. ${ }^{a}$ B., HAUTVAST J.G. ${ }^{a} J$. AND STEEGERS-THEUNISSEN R.P.M. - Dietary folate from vegetables and citrus fruit decreases plasma homocysteine concentrations in humans in a dietary controlled trail. J. Nutri, 129:1135-1139, 1999.

Jacob RA, WU M., HENNING SM., AND SWENSEID ME. - Homocysteine Increases as folate decreases in plasma of healthy men during short-term dietary folate and methyl group restriction. J. Nutr. 124:1072-1080, 1994.

JACOBSON DW, GATAUTIS VJ, GREEN R, ROBINSON K, SSAVON SR, SECIC M, Jl J, OTTO JM, TAYLOR LM. Rapid HPLC. - Determination of total homocysteine and other thiols in serum and plasma : Sex differences and correlation with cobalamin and flate concentrations in healthy subjects. Clin. Chem. 40:873-881, 1994.

JACQUES PF, BOSTOM AG, WILLIAMS RR, ELLISON RC, ECKFELDT JH, ROSENBERG IH, SELHUB J, ROZEN R - Relation between the folate status a common mutation in methylenetrahydrofolate reducatse and plasma homocysteine concentrations. Circulation, 93: 7-9, 1996. 
JAKUBOWSKI H. - Metabolism of homocysteine thiolac-tone in human cell cultures. Possible mechanism for pathological consequences of elevated homocysteine levels. J. Biol. Chem. 272: 1935-1942., 1997

JAKUBOWSKI H. - Homocysteine thiolactone: Metabolic origin and protein homocysteinylation in humans. J. Nutr. 130(Suppl): 377S-381S.,2000 KANANI PM, SINKEY CA, BROWNING RL, ALLAMAN M, KNAPP HR, AND HAYNES WG. - Role of oxidant stress in endothelial dysfunction produced by experimental hyperhomocyst(e)inemia in humans. Circulation, 100: 1161-1168., 1999.

KANG SS, WONG PWK, NORUSIS M. - Homocysteinemaia due to folate deficiency. Metabolism, 36: 458-462, 1987.

KEEBLER ME, DE SOUZA C, FONSECA V. - Diagnosis and treatment of hyperhomocysteinemia. Curr. Atheroscler. Rep. 3(1):54-63, 2001.

KELLY P, MCPARTLIN J, SCOTT J. - A combined high performance liquid chromatographic microbiological assay for serum folic acid. Anal. Biochem. 238:179-183, 1996.

KHAJURIA A AND HOUSTON DS. - linduction of monocyte tissue factor expression by homocysteine: A possible mechanism for thrombosis. Blood, 96:966-972, 2000

KLEE GG. - Cobalamin and folate evalutation: Measurement of methylmalonic acid and homocysteine vs vitamin B12 and folate. Clin. Chem. 46(8): 12771283. 2000.

KOEHLER KM, BAUMGARTNER RN, GARRY PJ, ALLEN RH, STABLER SP, RIMM EB. - Association of folate intake and serum homocysteine in elderly 
persons according to vitamin supplementation and alcohol use ${ }^{1-3}$. Am. J. Clin. Nutr. 73: 628-37, 2001.

KOKAME $\mathrm{K}$, KATO $\mathrm{H}$, AND MIYATA T. - Homocysteine-respondent genes in vascular endothelial cells identified by differential display analysis. GRP78/BiP and novel genes. J. Biol. Chem. 271: 29659-29665., 1996.

KRAJCOVICOVA-KUDLACKOVA m, BLAICEK P, BABINSKA K, KOPSOVA J, KLVANOVA J, BEDEROVA A, MAGALOVA T. - Traditional and alternative nutrition-levels of homocysteine and lipid parameters in adults. Scand. J.clin. Lab. Invest. 60(8): 657-64, Dec 2000.

KRAJCOVICOVA-KUDLACKOVA M, BLAZICEK P, KOPCOVA J, BEDEROVA A, BAINSKA K. - Homocysteine levels in vegetarians versus omnivores. Ann. Nutr. Metab. 44(3):135-138, 2000.

KRUMDIECK CL AND PRINCE CW. - Mechanisms of homocysteine toxicity on connective tissues: Implications for the morbidity of aging. J. Nutr. 130: 365S-368S., 2000.

KWITEROVICH PO. Jr. - The effect of dietary fat, antioxidants, pro-oxidants on blood lipids, lipoproteins, and atherosclerosis. Am. Diet. Assoc. 97(Suppl)S31-41, 1996.

LAKSHMI AV, RAMALAKSHMI BA - Effect of pyridoxine or riboflavin supplementation on plasma homocysteine levels in women with oral lesions. Natl. Med. J. India, 11:171-172, 1998.

LANG D, KREDAN MB, MOAT SJ, HUSSAIN AS, POWELL CA, BELLAMY MF, POWERS HJ, LEWIS MJ. - Homocysteine-induced inhibition of endotheliumdpendent relaxation in rabbit aorta: Role for superoxide anions. Arterioscler. Thromb. Vasc. Biol. 20: 422-472., 2000 
LANGMAN LJ, COLE DE . - Homocysteine. Crit. Ver. Clin. Lab. Sci. 36(4): 365406, 1999.

LECLERC D., WILSON ${ }^{\text {a }}$, DUMAS R. GAFUIK C., SONG D., WATKINS D., HENG HHK, ROMMEN JM., SCHERER SW, ROSENBLATT DS AND GRAVEL RA.

- Cloning and mapping of a cDNA for methionine synthase reductase a flavoprotein defective in patients with homocysinuria. Proc. Natl. Acad. Sci. USA, 95: 3059-3064, 1998

LEE ME AND WANG H. - Homocysteine and hypomethy-lation. A novel link to vascular disease. Trends Cardiovasc. Med. 9: 49-54., 1999

LENTZ SR AND SADLER JE. - Inhibition of thrombomodulin surface expression and protein $\mathrm{C}$ activation by the thrombo-genic agent homocysteine. J. Clin. Invest. 88: 1906-1914., 1991

LENTZ SR AND SADLER JE. - Homocysteine inhibits von Willebrand factor processing and secretion by preventing transport from the endoplasmic reticulum. Blood, 81: 683-689., 1993

LENTZ SR, SOBEY CG, PIEGORS DJ, BHOPATKAR MY, FARACI FM, MALINOW MR, HEISTAD DD. - Vascular dysfunction in monkeys with dietinduced hyperhomocyst(e)inemia. J. Clin. Nvest. 98: 24-29, 1996.

LENTZ SR. - Homocysteine and vascular dysfunction. Life Sci. 61:1205-1215., 1997

LENTZ SR, ERGER RA, DAYAL S., MAEDA N., MALINOW MR., HEISTAD DD AND FRACI FM. - Folate dependence of hyperhomocysteinemia and vascular dysfunction in cystathionine beta-synthase-deficient mice. Am. J. Physiol. 279: H970-H975, 2000. 
LENTZ S.R., PIEGORS D.J. MALINOW M.R., HEISTAD D.D. - Supplementation of atherogenic diet with B vitamins does not prevent atherosclerosis or vascular dysfunction in monkeys. Circulation, 103(7):1006-1011, 2001.,

LORIA CN, INGRAM DD, FELDMAN JJ, WRIGHT JD, MADANS JH. - Serum folate and cardiovascular disease mortality among US men and women. Arch. Intern. Med. 160(21): 3258-62, 2000.

LOSCALZO J. - The oxidant stress of hyperhomocys-t(e)inemia. J. Clin. Invest. 98: $5-7 ., 1996$

LUBEC B, FANG-KIRCHER S, LUBEC T, BLOM HJ, AND BOERS GHJ. Evidence for McKusick's hypothesis of deficient collagen cross-linking in patients with homocystinuria. Biochim. Biophys. Acta. 1315:159-162., 1996

LUSSIER-CACAN S, XHIGNESSE M, PIOLOT A, SELHUB J, DAVIGNON J, AND GENEST J JR. - Plasma total homocysteine in healthy subjects: Sexspecific relation with biological traits. Am. J. Clin. Nut.r 64: 587-593., 1996

MALINOW, MR. - Hyperhomocys(e)inemia. A common and easily reversible risk factor for occlusive atherosclerosis. Circulation. 81: 2004-6, 1990.

MALINOW, MR. - Homocyst(e)ine and arterial occlusive diseases. J. Intern. Med. 236: 603-17, 1994.

MALINOW, MR., SEXTO, G., AVERBUCH, M., GROSSMAN, M., WILSON, D., UPSON, B. - Homocyst(e)ine in daily practice: levels in coronary artery disease. Coronary artery dis. 1:215-20, 1990.

MALINOW MR, DUELL PB, HESS DL, ANDERSON PH, KRUGER WD, PHILLIPSON BE, GLUCKMAN RA, BLOCK PC AND UPSON BM. Reduction of plasma homocyst(e)ine levels by breakfast cereal fortified with 
folic acid in patients with coronary heart disease. N. Engl. J. Med, 338:1009$1015,1998$.

MALINOW, MR., ANDREW, GB., RONALD, MK. - Homocyst(e)ine, diet, and cardiovascular disease. A statement for healthcare professionls from the nutrition committee, American Heart Association. Circulation. 99: 178-182, 1999.

MALINOW MR, KANG SS, TAYLOR LM. et al. - Prevalence of hyperhomocysteinemia in patients with peripheral arterial occlusive disease. Circulation, 79:1180-1188, 1989.

MANSOOR MN, KRISTENSEN O, HERVIG T. et al. - Plasma total homocysteine response to oral doses of folic acid and pyridoxine hydrochloride (vitamin B6) in healthy individuals. Oral doses of vitamin B6 reduce concentrations of serum folate. Scand. J. Clin. Lab. Invest. 59:139-146, 1999.

MANSOOR MA, BERGMARK C, SVARDAL AM, LONNING PE, UIELAND PM, Redox status and protein binding of plasma homocysteine and other aminothiols in patients with early-onset peripheral vascular disease: homocysteine and peripheral vascular disease. Arterioscler. Thromb. $15: 232-240,1995$

MANSOOR MA, GUTTORMSEN A, FISKERSTRAND T, REFSUM $H$, UELAND PM AND SVARDAL AM. - Redox status and protein binding of plasma aminothiols during the transient hyperhomocysteinemia that follows homocysteine administration. Clin. Chem. 39: 980-985., 1993.

MANSOOR MA, UELAND PM AND SVARDAL AM - Redox status and protein binding of plasma homocysteine and other aminothiols in patients with 
hyperhomocysteinemia due to cobalamin deficiency. Am. J. Clin. Nutr. 59: 631-635., 1994.

MARKS DB, MARKS AD, SMITH CM. - Basic Medical Biochemistry: a clinical approach. Williams and Wilkins, Baltimore MD, 1996.

MASON J.B., MILLER JW. - The effects of B12, B6 and folate on blood homocysteine levels. In Sauberlich HE, Machlin LJ., eds. Beyond deficiency: new views on the function and health effects of vitamins. New York: the Ney York Academy of Sciences, 360-362, 1992.

MATO JM., ALVAREZ L., ORTIZ P., PAJARES MA. - S-Adenosylmethionine synthesis: molecular mechanisms and clinical implications. Pharmacol. Ther. 73: 265-80, 1997.

MCCULLY, KS. - The Homocysteine Revolution, Keats Publishing, Inc. New Canaan, Connecticut. 1997.

McCULLY KS. - Homocysteine and vascular disease. Nature Med. 2: 386-389. 1996

MCCULLY KS. - Homocysteine theory of arteriosclerosis:Development and current status. Atherosclerosis Ver. 11:157-246, 1983.

MCCULLY KS. - Vascular pathology of homocysteinemai: Implications for the pathogenesis of arteriosclerosis. Am. J. Path. 56:111-28, 1969

MCCULLY K.S., OLSZEWSKI A J. AND VEZERIDIS.M.P. - Homocysteine and lipid metabolism in atherogeneis: effect of the homocysteine thiolactonyl derivatives. Thioretinaco and thioretinamide. Atherosclerosis, 83: 197-206, 1990.

McKAY DL, PERRONE G, RASMUSSEN H, DALLAL G, BLUMBERG JB., Multivitamin/Mineral supplementation imporves plasma B-vitamin status and 
homocysteine concentration in healthy older adults consuming a folatefortified diet. J. Nutr. 130: 3090-3096, 2000.

MCKEEVER WP, WEIR DG, MOLLOY A, SCOT JM. - Betaine-homocysteine methyltransferase: Organ distributions in man pig and rat subcellular distribution. Clin. Sci. 81: 551-556,1991.

McKINLEY JC, McNULTY H, McPARTLIN J, STRAIN JJ, PENTIEVA K, WARD M, WEIR DG, SCOTT Mj. - Low-dose vitamin B-6 effectively lowers fasting plasma homocysteine in healthy elderly persons who are folate and riboflavin replete. Am. J. Clin. Nutr. 73: 759-764. 2001.

MIELYNK S, POGRIBNA M, POGRIBNY IP, YI P, JAMES SJ. - Measurement of plasma and intracellular S-adenosylmethionine and S-adenosylhomocysteine utilizing coulometric electrochemical detection:Alterations with plasma homocysteine and pyridoxal 5'-phosphate concentrations. Clin. Chem. 46 : 265-272. 2000 .

MIDORIKAWA $S$, SANDA $H$, HASHIMOTO $S$ AND WATANABE $T$. Enhancement by homocysteine of plasminogen activator inhibitor-1 gene expression and secretion from vascular endothelial and smooth muscle cells. Biochem. Biopys. Res. Comm. 272: 182-185., 2000.

MIJATOVIC V,KENEMANS P, JAKOBS C, VAN BALL MV, PETERS-MULLER ER AND VAN DER MOOREN MJ. - A randomized controlled study of the effects of 17 beta-estradiol-dydrogesteron on plasma homocysteine in postmenopausal women, Obstet. Gynecol. 91: 432-436, 1998.

MOLGAARD J., MALINOW MR., LASSVIK C, HOLM AC., UPSON B., OLSSON AG. - Hyperhomocyst(e)inaemia: na independent risk factor for intermittent claudication. J Intern. Med. 231: 273-9, 1992. 
MOLLOY AM , DALY S, MILLS JL, KIRKE PH, WHITEHEAD AS, RAMSBOTTOM D., CONLEY MR., WEIR DG AND SCOTT JM. - Thermolabile variant of 5,10-methylenetetrahydrofolate redutase associated with low red-cell folates: implication for folate intake ecommendations:, Lancet, 349: 1591-93,1997.

MORRISON HI, SCHAUBEL D, DESMEULES M AND WIGLE DT. - Serum folate and risk of fatal coronoary heart disease. JAMA, 275:1893-1896., 1996.

MORSHAROV E, CRANFORD MR AND BANERJEE R. - The quantitatively important relationship between homocysteine metabolism and glutathione synthesis by transsulfuration pathway and its regulation by redox changes. Biochemistry, 39:13005-13011, 2000.

MUDD SH., LEVY HL. Et al. - Disorders of transsulfuration: In: Scriver CR, Beaudet Al. Sly Ws., Valle D. eds. The Metabolic and Molecular Bases of Inherited disease. $1^{\text {st }}$ edn. Vol 1. New York: McGraw-Hill, 1279-327, 1995.

MUDD SH, SKOVBY F., LEVY HL et al. - The natural history of homocystinuria due to cystathionine $\beta$-synthase deficiency. Am. J.Hum. Genet. 37:1-3, 1985 MULLER T, HAIDINGER D, LUFT C, HORVATH W, POELZ W,HALTMAYER M. Associations between erythrocyte mean corpuscular volume and peripheral and arterial disease in male subjects: a case control study. Angiology, 52(9): $605-13,2001$

MUNDAY R - Toxicity of thiols and disulphides: Involvement of free-radical species. Free Radic. Biol. Med. 7: 659-673. 1989.

MURDOCH JC., RODGER JC., RAO SS. FLETCHER CD, DUNNINGAN MG. Down's syndrome: na atheroma-free model?. Br. Med. J. 2: 26-8, 1977. 
NALLAMTHU BK, FENDRICK AM, RUBENFIRE M, SAINT S, BANDEKAR RR, OMENN GS. Potential clinical and economic effects of Homocyst(e)ine lowering. Arc. Internal. Med. 160(22): 3506-3412, 2000.

NAPPO F, DeROSA N, MARFELLA R, DeluCIA D, INGROSSO D., PERNA AG, FARZATI B, AND GIUGLIANO D. - Impairment of endothelial functions by acute hyperhomocysteinemia and reversal by antioxidnt vitamins. JAMA, 281: $2113-2118,1999$.

NISHINAGA M, OZAWA T, AND SHIMADA K. - Homocysteine, a thrombogenic agent, suppresses anticoagulant heparan sulfate expression in cultured porcine aortic endothelial cells. J. Clin. Invest. 92: 1381-1386., 1993

NORLUND L, GRUBB A, FEX G. - The increase of plasma homocysteine concentrations with age in part ot the deterioration of renal function as determined by plasma cystatin. Clin. Chem. Lab. Med. 36:175-178, 1998.

NYGÅRD O, REFSUM H, UELAND PM, AND VOLLSET SE - Major lifestyle determinants of plasma total homocysteine distribution: The Hordaland Homocysteine Study. Am. J. Clin. Nutr. 67: 263-270., 1998

NYGARD O, VOLLSET SE, REFSUM $H$, STENSVOLD I., TVERDAL A, NORDREHAUG JE, UELAND PM AND KVALE G. - Total plasma homocysteine and cardiovascular risk profile. The Hordaland homocysteine study. JAMA, 274:1526-1533.

NYGARD O., S.E. VOLLSET, H. REFSUM, L.BRATTSTROM AND P.M. UELAND, - total Homocysteine and cardiovascular disease J. Int. Med. 246: 425-454. 1999

O'LEARY K, SHEEHY PJ. - Influence of folic acid-fortified foods on folate status in a folate depletion-repletion rat mode Br. J. Nutr. 85(40): 441-6, 2001. 
OLSZEWSKI AJ AND MCCULLY KS. - Homocysteine content of lipoproteins in hypercholesterolemia. Atherosclerosis, 88:,61-69., 1991

OLSZEWSKI AJ AND MCCULLY KS. - Homocysteine metabolism and the oxidative modification of proteins and lipids. Free Radic. Biol. Med. 14: 683693., 1993

OUTINEN PA, SOOD SK, LIAW PCY, SARGE KD, MAEDA N, HIRSH J, RIBAU J, PODOR TJ, WEITZ JI, AND AUSTIN RC. - Characterization of the stressinducing effects of homocysteine. Biochem. J. 332: 213-221. 1998.

PAGAN K, HOU J, GOLDENBERG RL, CLIVER SP, TAMURA T. - Effect of smoking on serum concentrations of total homocysteine and B vitamins in mid pregnancy. Clinica Chimica. Acta. 306:.103-109, 2001.

PANCHARUNITI n., LEWIS C.A.,SAUBERLICH H.E. PERKINS L.L., GO R.C.P., ALVAREZ J. ${ }^{\circ}$, MCALUSO M., ACTON T.T., COPELAND R.B. COUSINS ${ }^{\circ}$ L., GORE T.B. CORNWELL P.E. AND ROSEMAN J.M. - Plasma homocyst(eine), folate and vitamin B-12 concentrations and risk for early onset coronary artery disease. Am. J. Clin. Nutr. 59: 940-948, 1994.

PANGANAMALA RV, KARPEN CW AND MEROLA AJ - Perioxide mediated effects of homocysteine on arterial proastacyclin synthesis. Protaglandins. Leuk. Med. 22: 349-356. 1986.

PASTEUR L - Address to the Fraternal Association of Former Students of Ecole Central de Artes et Manufactures, Paris, Nay 15, 1885 em Familiar Medical Quotations, Ed. Strauss MD. Little Brown and Company, Boston, 1968. PERRY DJ . - Hyperhomocysteinaemai. Bailliere's Clin. Haematology, 12(3): $451-477,1999$. 
PERRY I.J., REFSUM H., MORRIS R.W., EBRAHIM S.B., UELAND P.M., SHAPRE AG. - Prospective study of serum homocysteine concentration and risk of stroke in middle-aged British men. Lancet, 346:1395-8, 1995

PETRI M, ROUBENOFF R, DALLAL GE, NADEAU MR, SELHUB J, AND ROSENBERG $\mathrm{H}$. - Plasma homocysteine as a risk factor for atherothrombotic events in systematic lupus erythemato-sus. Lancet, 348:1120-1124., 1996

PFEIFFER CM, HUFF DL AND GUNTER EW . - Rapid and accurate HPLC assay for plasma total homocysteine and cysteine in a clinical laboratory setting. Clin. Chem. 45: 290-292, 1999.

QI LING AND K.A HAJJAR - Inhibition of Endothelial Cell Trhomoboresistance by Homocysteine. J. Nutr. 130: 373S-376S, 2000.

QUINILVAN EP, McPARTLIN J, McNUTTY H, WARE M, STRAIN JJ, WEIR DG, SCOTT JM. - Importance of both folic acid and vitamin B12 in reduction of the risk of vascular disease., Lancet, 359: 227-228, 2002.

RASMUSSEN LB, OVESEN L, BULOW I, KNUDSEN N, LAURBERG P, AND PERRILD H. - Folate intake, lifestyle factors, and homocysteine concentrations in younger and older women. Am. J. Clin. Nutr. 72:.11561163., 2000.

RAY JG, COLE DEC, BOSS SC - An Ontario-wide study of vitamin B12, Serum folate, and red cell folate levels in relation to plasma homocysteine: is a preventable public health issue on the rise. Clinical Biochemistry, 33(5): $337-343,2000$. 
RAYAN M, ROBINSON K, CLARKE R,REFSUM H, UELAND $p$, GRAHAM I Vitamin B6 and folate reduce homocysteine concentrations in coronary artery disease. Ir. J. Med. Sci, 162: 197, 1993.

REFSUM H, HELLAND S, UELAND PM. - Radioenzymic determination of homocysteine in plasma and urine. Clin. Chem. 31: 624-8, 1985.

RIDDEL LJ., CHISHOLM ${ }^{\text {a }}$, WILLIAMS S., AND MANN JI. - Dietary strategies for lowering homocysteine concentrations. Am. J. Clin. Nutr. 71:1448-54, 2000. RIMM EB, WILLETT WC, HU FB, SAMPSON L, COLDITZ GA, MANSON JE, HENNEKENS C, AND STAMPFER MJ. - Folate and vitamin B6 nfrom diet and supplements in relation to risk of coronary heart disease among women. JAMA, 279: 359-364. 1998.

ROBINSON K, ARHEART K, REFSUM H, BRATTSTRÖM L, BOERS G, UELAND P, RUBBA P, PALMA-REIS R, MELEADY R, DALY L, WITTEMAN J, AND GRAHAM I. - Low circulating folate and vitamin B6 concentrations: Risk factors for stroke, peripheral vascular disease, and coronary artery disease. Circulation, 97: 437-443., 1998

ROBINSON K, MAYER EL, MILLER DP, GREEN R, Van LENTE F, GUPTA A, KOTTKE-MARCHANT K, SAVON SR, SELHUB J, NISSEN SE, KUTNER M, TOPOL EJ, JACOBSEN DW. - Hyper homocysteinemia and low pyridoxal phosphate. Common and independent reversible risk factors for coronary artery disease. Circulation, 92:,2825-2830, 1995.

RODGERS GM AND CONN MT - Homocysteine an atherogenic stimulus, reduces protein $\mathrm{C}$ activation $\mathrm{b}$ arterial and venous endothelial cells. Blood, 75:,895-901. 1990 
ROSENBLATT DS - Inherited disorders of folate transport and metabolism. Em Scriver CR, Beaudet Al, Sly WS and Valle D, editors, Metabolic basis of inherited disease. New York, McGraw-Hill, 3111-3128.1995

SAMPSON DA., O'CONNOR, Nutr. Res. 9: 259, 1989.

SANCHEZ SE, ZHNG C, MALINOW NR, WAREJAUREGUI S, LARABURE G., WILLAMS MA. - Plasma folate, vitamin B12 and homocyst(e)ine concentrations in preeclamptic and normotensive Peruvian women. Am. J. epidemiol. 153(5): 474-80, 2001.

SAW SM, YUAN JM, ONG CN, ARAKAWA K, LEE HP, COETZEE GA, YU MC. Genetic, dietary, and other lifestyle determinants of plasma homocysteine concentrations in middle- aged and older Chinese men and women in Singapore. Am. J. Clin. Nutr. 73(2): 232-9, 2001.

SCHAEFER EJ . - Lipoproteins, nutrition, and heart disease. Am. J. Clin. Nutr. $75(2): 191-212,2002$

SCHIMKE RN., McKUSICK VA., HUANG T., POLLAC AD. - Homocystinuria. Studies of 20 families with 38 affected members. JAMA, 193: 87-95, 1965.

SCHNEEDE J, REFSUM $H$, UELAND PM - Biological and environmental determinants of plasma homocysteine. Seminars in Thromobosis and Hemostasis, vol 26: 263-280, 2000.

SCHÖNEICH C, ASMUS K-D, DILLINGER U, AND VON BRUCHHAUSEN F Thiyl radical attack on polyunsaturated fatty acids: A possible route to lipid peroxidation. Biochem. Biophys. Res. Commun 161:113-120., 1989

SCOTT J. WEIR D. - Homocysteine and cardiovascular disease. QJM, 89:.561$563,1996$. 
SELHUB J, JACQUES PF, BOSTOM AG., et al. - Association between plasma homocysteine concentrations and extracranial carotid-artery stenosis. New Engl.J.Med. 332:.286-91, 1995.

SELHUB J., JACQUES PF., WILSON PWF. RUSH D., ROSENBER IH. vitamin status and intake as primary determinants of homocysteinemai in na elderly population. JAMA, 270:.2693-8, 1993.

SELHUB J AND MILLER JW. - The pathogenesis of homocysteinemia: Interruption of the coordinate regulation by S-adenosylmethionine of the remethylation and transsulfuration of homocysteine. Am. J.Clin. Nutr. $55: 131-138,1992$

SILBERBERG J, CROOKS R, FRYER J, WLODARCZYK J, NAIR B, GUO XW, XIE LJ, AND DUDMAN N. - Gender differences and other determinants of the rise in plasma homocysteine after L-methionine loading. Atherosclerosis, 133:105-110., 1997

SIMON MO., ROSOLOVA H - A population study of the influence of beer consumption on folate and homocysteine concentrations. Eur. J. Clin. Nutr $55(7): 605-9,2001$

SMOLIN LA, SCHNEIDER JÁ - Measurement of total plasma cysteamine using high performance liquid chromatography with electrochemical detection. Ann. Biochem, 168: 374-379, 1988.

SPARROW CP AND OLSZEWSKI J - Cellular oxidation of low density lipoprotein is caused by thiol production in media containing transition metal ions. J. Lipid. Res. 34:1219-1228. 1993

STABLER S.P. MARCELL PD.D. POWELL ER. et al. - Evaluation of total homocysteine in the serum of patients with cobalamin or folate deficiency 
detected by capillary gas chromatography-mass spectrometry. J. Clin. Invest. 81:.466-74, 1988.

STAMFER, MJ., MALINOW, MR., WILLETT, WC., NEWCOMIER, LM., UPSON,B., ULLMANN, D., TISHLER, PV., HENNEKENS, CH. - A prospective study of plasma homocyst(e)ine and risk of myocardial infration in US Physicians. JAMA, 268: 877-81, 1992.

STMLER JS, OSBORNE JÁ, JARAKI O, RABBANI LE, MULLINS M, SINGEL D AND LOSCALZO J - Adverse vascular effects of homocysteine are modulated by endothelium-derived relaxing factor and related oxides of nitrogen. J. Clin. Invest. 91: 308-318. 1993.

STAMILER JS AND SLIVKA A - Biochemical chemistry of thiols in the vasculature and in vascular-related disease. Nutr. Rev. 54:1-30, 1996.

STARKEBAUM G AND HARLAN JM. - Endothelial cell injury due to coppercatalyzed hydrogen peroxide generation from homocysteine. J. Clin. Invest. $77: 1370-1376 ., 1986$

SUDEN SLF., RENDUCHINTALA MS. PARK EI. MIKLASZ SD. GARRAW TA. Betaine-homocysteine methyltransferase expression in porcine and human tissues and chromosomal localization of the human gene. Arch. Biochem Biophys. 345:171-4, 1997.

SUPERKO H.R. - New aspects of risk factor for the development of atherosclerosis, including small low-density lipoprotein, homycyst(e)ine and lipoproteina(a), Current Science, 1995, 347-354., 1995

TAOKA S, OHJA S, SHAN X, KRUGER WD AND BANERJEE R. - Evidence for heme-mediated redox regulation of human cystahionine beta-synthase activity, J. Biol. Chem. 273:.25179-25184. 1998. 
TAWAKOL A, OMLAND T, GERHARD $M$, WU JT AND CREAGER MA. Hyperhomocyst(e)inemia is associated with impaired endothelium-dependent vasodiation in humans. Circulation, 95:1119-1121. 1997.

TAYLOR LM. Jr, DeFRANG RD., HARRIS EJ Jr., PORTER JM. - The association of elevated plasma homocyst(e)ine with progression of syrnptomatic peripheral arterial disease. J.Vasc. Surg. 13:128-36, 1991.

TELLING OV, SIPS JHM .- Bioanalysis of the investigational antitumor drug 5,10-dideaza-5,6,7,8-tetrahydrofolic acid by high performance liquid chromatography with ultraviolet detection. J. Chrom. 576:158-162, 1992.

TONSTAD S, REFSUM SIVERTSE M - Relation of total homocysteine and lipid levels in children to premature cardiovascular death in male relatives., Pediatr. Res. 40: 47-52

TSAI J-C, PERRELLA MA, YOSHIZUMI M, HSIEH C-M, HABER E, SCHLEGEL R, AND LEE M-E - Promotion of vascular smooth muscle cell growth by homocysteine: A link to atherosclerosis. Proc. Natl. Acad. Sci. USA, 91: 6369-6373., 1994.

TSAI JC, WANG $H$, PERRELLA MA, YOSHIZUMI M, SIBINGA NES, TAN LC, HABER E, CHANG THT, SCHLEGEL R, AND LEE ME. - Induction of cyclin a gene expression by homocysteine in vascular smooth muscle cells. J. Clin. Invest. 97:146-153., 1996.

TYAGI SC. - Homocysteine redox receptor and regulation of extracellular matrix components in vascular cells. Am. J. Physiol. 274: C396-C405., 1998.

UBBINK JB, VERMAAK WJH, BENNETT, JM., BECKER PJ. VAN STADEN, DA. - The prevalence of homocysteinemia and hypercholesterolemia in 
angiographically defined coronary heart disease. Klin. Wochenschr. 69: 527-34, 1991a.

UBBINK JB, VERMAAK WJH, BISSBORT S - rapid high performance liquid chromatographic assay for total homocysteine levels in human serum. J. Chromat. 565: 441-446, 1991 b.

UBBINK JB, VERMAAK WJH, VAN DER MERWE A, BECKER PJ. - The effect of blood sample aging and food consumption on plasma total homocysteine levels. Clin. Chim. Acta. 207:119-28, 1992

UBBINK JB, VERMAAK WJH, VAN DER MERWE A, BECKER PJ. - Vitamin B12, vitamina B6, and folate nutritional status in men with hyperhomocysteinemia, American Jornal of Clinical Nutrition, January 57: 47-53, 1993.

UBBINK JB. - Vitamin nutrition status and homocysteine: An atherogenic risk factor. Nutr Rev 52:383-387., 1994.

UBBINK JB. - Should all elderly people receive folate supplements?. Drugs Aging, 13: 415-420, 1998.

UELAND PM, MANSOOR MA, GUTTORMSEN AB, MÜLLER F, AUKRUST P, REFSUM H, AND SVARDAL AM. - Reduced, oxidized and protein-bound forms of homocysteine and other aminothiols in plasma comprise the redox thiol status - A possible element of the extracellular antioxidant defense system. J. Nutr. 126:1281S-1284S., 1996.

UELAND, PM., REFSUM, H., BRATTSTROM L. - Plasma homocysteine and cardiovascular disease in: Francis RB Jr, ed. Atherosclerotic cardiovascular disease, hemosrasis, and endothelial funtion. New York: Marcel Dekkar, 183-236, 1992. 
UELAND PM, REFSUM $H$, STABLER SP, MALINOW MR, ANDERSSON A, ALLEN RH. - Total homocysteine in plasma or serum:Methods and clinical applications. Clin. Chem. 39:1764-1779, 1993.

UELAND PM AND REFSUM H. - Plasma homocysteine, a risk factor for vascular disease: Plasma levels in health, disease and drug therapy. J. Lab. Clin. Med. 114:.473-501, 1989.

UNDAS A, WILLIAMS EB, BUTENAS $S$, ORFEO T, AND MANN KG. Homocysteine inhibits inactivation of factor Va by activated protein C. J. Biol. Chem. 276:.4389-4397., 2001

UNGVARI Z, PACHER P, RISCHÁK K, SZOLLÁR L, AND KOLLER A . Dysfunction of nitric oxide mediation in isolated rat arterioles with methionine diet-induced hyperhomocysteinemia. Arterioscler. Thromb. Vasc. Biol. 19:1899-1904., 1999.

UPCHURCH GR JR, WELCH GN, FABIAN AJ, FREEDMAN JE, JOHNSON JL, KEANEY JF JR, AND LOSCALZO J. - Homocyst(e)ine decreases bioavailable nitric oxide by a mechanism involving glutathione peroxidase. $\mathbf{J}$. Biol. Chem. 272:17012-17017., 1997

VAHERISTO LT, OLLILAINEN V, VARO P . - Liquid chromatographic determination of olate monoglutametes in fish, meat, egg and airy products consumed in Finland. J. AOAC Inter. 80(2): 373-378, 1997 a.

VAHTERISTO L, LEHIKOINEN K, OLLILAINEN V, VARO P. . - Application of na HPLC assay for the determination of folate derivates in some vegetables, fruits and berries consumed in Finland. Food Chem. 59(4): 589-597, 1997b VAN DEN BERG M, STEHOUWER CDA, BIERDRAGER E, AND RAUW-ERDA JA - Plasma homocysteine and severity of athero-sclerosis in young 
patients with lower-limb atherosclerotic disease. Arterioscler. Thromb. Vasc. Biol. 16:165-171. 1996

Van den BERG M, BOERS GHJ, FRANKEN DG, BLOM HJ, Van KEMP GJ, JAKOBS C, RAUWERDA JÁ, KLUFT C, AND STEHOUWERT CDA. Hyperhomocysteinaemia and entothelial dysfunction in young patients with peripheral arterial occlusive disease. Eur. J. clin. Invest. 25:176-181, 1995.

VAN DER GRIEND R, BIESMA DH, HAAS FJ, FABER JA, DURAN $M$, MEUWISSEN OJ, AND BANGA JD. - The effect of different treatment regimens in reducing fasting and postmethionine-load homocysteine concentrations. J. Intern. Med. 248: 223-229.,2000

VENTURA P, PANINI R, VERLATO C, SCARPETTA G, AND SALVIOLI G. Peroxidation indices and total antioxidant capacity in plasma during hyperhomocysteinemia induced by methio-nine oral loading. Metabolism 49: $225-228 ., 2000$

VERHAAR MC, STROES E, RBELINK TJ . - Folates and cardiovascular disease. Arterioscler. Thromb. Vasc. Biol. 22(1): 6-13, 2002.

VERHOEF P, HENNEKENS CH., MALINOW MR., KOK FJ., WILLETT WC., STMPFER MJ. - A propective study of plasma homocyst(e)ine and risk of ischemic stroke. Stroke, 25:1924-30, 1994.

VERHOEF, P., STAMFER, MJ. - Prospective studies of homocysteine and cardiovascular disease. Nutr. Ver. 53: 283-8, 1995.

VERMIEULEN EG, STEHOUWER CD, TWISK JW, VAN DEN BM, DE JONG SC, MACKAAY AJ, VAN CAMPEN CM, VISSER FC, JAKOBS CA, BULTERJIS EJ, AND RAUWERDA JA - Effect of homocysteine-lowering treatment with 
folic acid plus vitamin B6 on progression of subclinical atherosclerosis: A randomized, placebo-controlled trial. Lancet, 355: 517-522.,2000

VESTER B, RASMUSSEN K. . - High performance liquid chromatography method for rapid and accurate determination of homocysteine in plasma and serum. Eur. J. Clin. Chem. Clin. Biochem. 29: 549-554, 1991.

Von EOCKERDSTEIN,A., MALINOW, MR., UPSON, B., HEINRICH,J., SCHULTE,H., SCHONFELD, R., KOHLER, E., ASSMANN, G. - Effects of age, lipoproteinas, and hemostatic parameters on the role of homocust(e)inemia as a cardiovascular risk factor in men. Arteriosclerosis. Thromb. 14: 460-4, 1994.

VOUTILAINEN S, MORROW JD, ROBERTS LJ II, ALFTHAN G, ALHO $H$, NYYSSÖNEN K, AND SALONEN JT - Enhanced in vivo lipid peroxidation at elevated plasma total homocysteine levels. Arterioscler. Thromb. Vasc. Biol. 19:1263-1266., 1999

VOUTILAINEN S., MORROW J.D., ROBERTS L.J., ALFTHAN G., ALHO H., NYYSSONEN K., SALONEN J.T. - Enhanced in vivo lipid peroxidation at elevated plasm total homocysteine levels., Arterioscler. Trhomb. Vasc. Biol. 19:1263-1266., 1999.

WALD DS, BISHOP L, WALD NJ, LAW M, HENNESSY E, WEIR D, MCPARTLIN J, SCOTT J. - Randomaized trail of folic acid supplimentation and serum homocysteine levels. Arch. Intern. Med. 161(5): 695-700, 2001.

WALL RT, HARLAN JM, HARKER LA AND STRIKER GE. - Homocysteineinduced endothelial cell injury in vitro: A model for the study of vascular injury. Thromb. Res. 18:113-121. 1980. 
WANG $\mathrm{H}$, YOSHIZUMI M, LAI KH, TSAI JC, PERRELLA MA, HABER E, AND LEE ME. - Inhibition of growth and p21ras methyl-ation in vascular endothelial cells by homocysteine but not cysteine. J. Biol. Chem. 272:.25380-25385., 1997

WANG J, DUDMAN NPB AND WILCKEN DEL - Effects of homcysteine and related compounds on prostacyclin production by cultured human vascular endothelial cells. Thromb. Haemost. 70:104-1052. 1993.

WELCH GN LOSCALZO J. - Homocysteine and atherothrombosis. N. Engl. J. Med. 338: 1042-1050, 1998.

WILCKEN DEL, WILCKEN B. - The pathogenesis of coronary artery disease. A possible role for methionine metabolism. J. Clin. Invest. 57:1079-82, 1976.

WILCKEN DE, WILCKEN B. - B vitamins and homocysteine in cardiovascular disease and gaing. Ann. NY Acad. Sci. 854:361-370, 1998.

WILLIAM B. KANNEL, M.D. E THOMAS J. THOM, B.A. - The Heart,1990 WILLIAMS, RR., MALINOW,MR., HUNT, SC., UPSON, B., WU, LL., HOPKINS, PM., STULTS, BN., KUIDA, H. - Hyperhomocyst(e)inemia in Utah siblings with early coronary disease. Coronary Artery. Dis. 1:.681-5, 1990.

WOO KS, CHOOK P, LOLIN YI, SANDERSON JE, METREWELI C, AND CELERMAJER DS. - Folic acid improves arterial function in adults with hyperhomocysteinemia. J. Am. Coll. Cardiol. 34: 2002-2006., 1999 WOO KS, CHOOK P, LOLIN YI, CHEUNG ASP, CHAN LT, SUN YY, SANDERSON JE, METREWELI C AND CELERMAJER DS Hypermocyst(e)inemaia is a risk factor for arterial endothelial dysfunction in humans. Circulation, 96:2542-2544. 1997. 
WOOD JL AND GRAHAM A - Structural requirements for oxidation of low-density lipoportein by thiols. FEBS Lett. 366: 75-80, 1995.

WOODSIDE JV.YOUNG IS. YARNELL JWG, MCMASTER AND EVENS AE. The effects of oral vitamin supplementation on cardiovascular risk factors. Proc. Nutr. Soc. 56: 479-488, 1997.

WU L.L. WU J., HUNT S.C., JAMES B.C., VINCENT G.M. WILLIAMS R.R., AND HOPKINS P.N. - Plasma Homocyst(e)ine as a risk factor for early familial coronary artery disease.Clin. Chem. 40(4): 552-561., 1994

wnw.saude.gov.br

YAP S, NAUGHTEN ER, WILCKEN B, WILCKEN DE, AND BOERS GH. Vascular complications of severe hyper-homocysteinemia in patients with homocystinuria due to cystathionine beta-synthase deficiency: Effects of homocysteine-lowering therapy. Semin. Thromb. Hemost. 26: 335-340, 2000

YI P, MELNYK S, POGRIBNA M, POGRIBNY IP, HINE RJ, AND JAMES SJ Increase in plasma homocysteine associated with parallel increases in plasma S-adenosylhomocysteine and lymphocyte DNA hypomethylation. J. Biol. Chem. 275: 29318-29323., 2000

YU HH, JOUBRAN R, ASMAI M, LAW T, SPENCER A, JOUMA M, RIFAI N. Agreement among four homocysteine assays and results in patients with coronary atherosclerosis and controls. Clin. Chem. 46: 258-264. 


\section{ANEXOS}




\section{Anexo I - Termo de Consentimento}

\section{Hiperhomocisteinemia e o Risco Cardiovascular}

Responsável: Dr. Edson Rodrigues

RG:

6.413.205

Endereço:

Fone:

Av. São Francisco de Assis, 218 - Bragança Paulista (011) 7844.8350

O abaixo assinado (nome, idade, RG, endereço)

declara que é de livre e espontânea vontade que está participando como voluntário do projeto de pesquisa supra-citado, de responsabilidade do Prof. Dr. Edson Rodrigues, sob supervisão dos médicos Newton Carlos Polimeno e José Jaime da Silva Teles Filho do HUSF. O abaixo-assinado está ciente que:

1. O objetivo da pesquisa é verificar os níveis plasmáticos de homocisteína e vitaminas $B 12, B 6$ e ácido fólico, e que para tal, serão coletados de 5 a $10 \mathrm{ml}$ de sangue através de punção de veia antecubital.

2. A participação neste estudo não the acarretará nenhum benefício terapêutico.

3. Obteve todas as informações necessárias para poder decidir conscientemente sobre a participação da referida pesquisa.

4. Os nome e dados referentes aos voluntários participantes da pesquisa serão mantidos em sigilo, e os autores não os identificarão pôr ocasião da exposição e/ou publicação dos mesmos.

5. Poderá contatar o Comitê de Ética em Pesquisa da USF para apresentar recursos ou reclamações em relação a pesquisa.

Bragança Paulista, de de

Nome do Voluntário:

Assinatura: 


\section{Anexo II - Carta da Comissão da Ética}

UNIVERSIDADE

Bragança Paulista, 03 de dezembro de 1997

\section{COMITÊ DE ÉTICA EM PESQUISA -USF}

Estudo: Hiperhomocisteinemia e o risco cardiovascular

Autores Prof. Dr. Édson Rodrigues

O CEP-USF, em sua reunião ordinária realizada em 28 de novembro de 1997, analizou o projeto supra-citado, näo encontrando nele qualquer infração dos códigos de ética em pesquisa

Parecer: o referido projeto está de acordo com as normas que regem a ética em pesquisa

Prof. Dr. José Pedcazzoli Júnior

Comitê de Ética em Pesquisa

Universidade São Francisco

CAATLS DE ITATIBA Ruz Alexandre Rorigues Barbosa 45 - CEP $13.251-900$ Fone (011) 7805-1262 - FAX (011) 7805-1933
CÁMTPUS DE SĀO PAULO Rua Hannernann 352 - Pari - CEP $03031-040$ Fone (011) 227-0255 - FAX (011) 227-8183 
Anexo III - Avaliação Nutricional Inquérito - 1

\section{UNIVERSIDADE SÃO FRANCISCO \\ Faculdade de Ciências Médicas}

Nome:

RG Data

Peso: Estatura: IMC:

Freqüência de Consumo de Alimentos

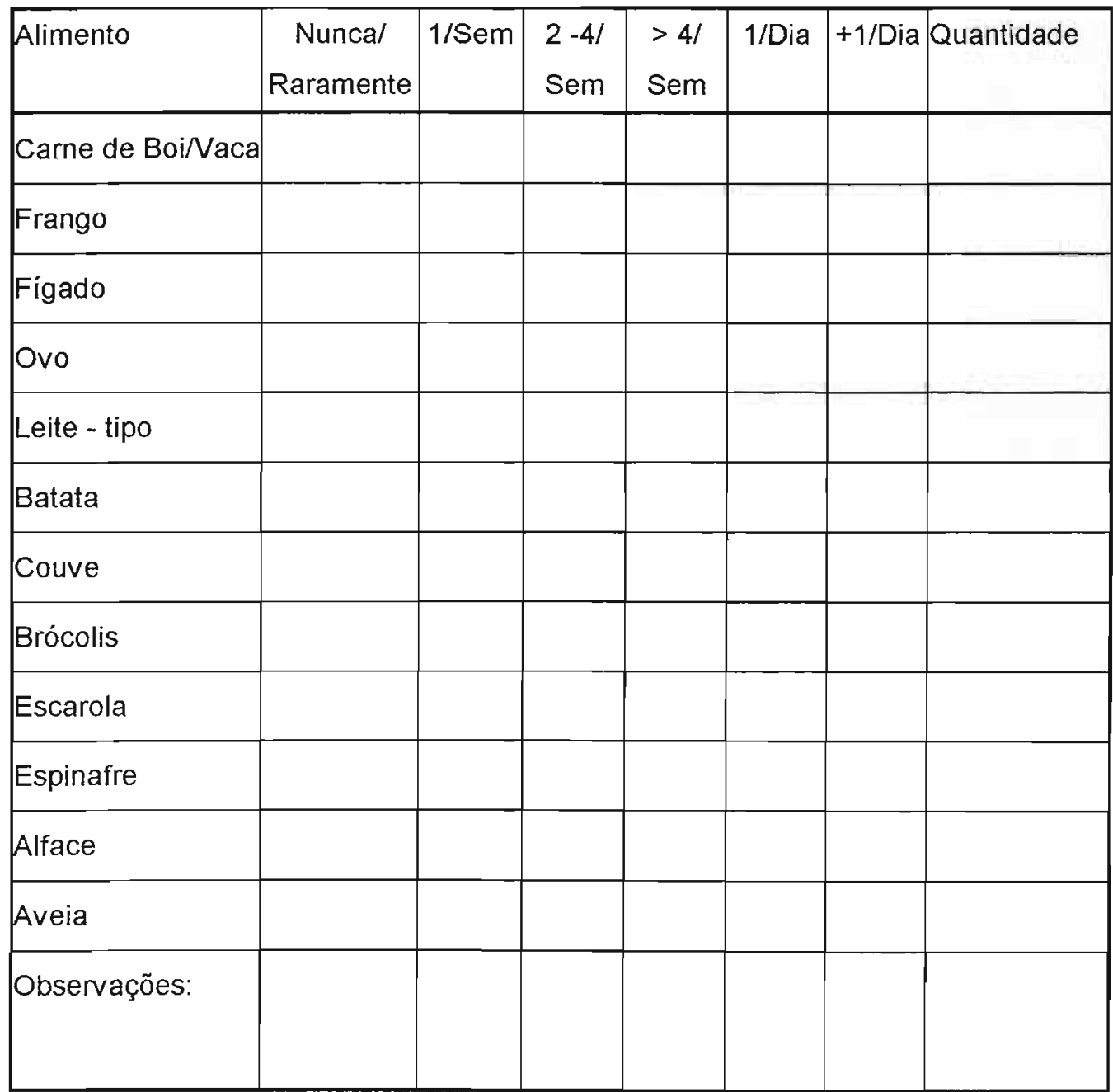


Anexo IV - Avaliação Nutricional Inquérito - 2

UNIVERSIDADE SÃO FRANCISCO

Faculdade de Ciências Médicas

Nome

RG.

Peso

Estatura

IMC

Paciente Rural /Urbano No Data

Frequiência de Consumo de Alimentos

\begin{tabular}{|c|c|c|c|c|c|c|c|c|}
\hline Alimento & $\begin{array}{l}\text { Nunca } \\
\text { Raramente }\end{array}$ & $1 /$ sem & $\begin{array}{l}2-4 / \\
\text { sem }\end{array}$ & $\begin{array}{l}>4 / \\
\text { sem }\end{array}$ & $\begin{array}{l}1 / \mathrm{di} \\
\mathrm{a}\end{array}$ & $+1 / d i a$ & $\begin{array}{l}\text { Forma de } \\
\text { preparo }\end{array}$ & Quantidade \\
\hline $\begin{array}{l}\text { Carne de } \\
\text { vaca e boi }\end{array}$ & & & & & & & 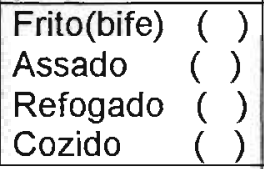 & \\
\hline Frango & & & & & & & 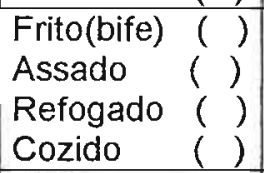 & \\
\hline Ovo & & & & & & & $\begin{array}{ll}\text { Frito } & (\text { ) } \\
\text { Cozido } & (\text { ( ) } \\
\text { Omelete } & (\text { ) }\end{array}$ & \\
\hline Leite-tipo & & & & & & & $\begin{array}{ll}\text { A } & (\text { ) } \\
\text { B } & (\text { ) } \\
\text { C/semi-des }(~) \\
\text { Desnatado ( ) } \\
\text { Integral ( })\end{array}$ & \\
\hline Batata & & & & & & & $\begin{array}{ll}\text { Frito } & (\text { ) } \\
\text { Assado } & (\text { ) } \\
\text { Refogado } & (\text { ) } \\
\text { Cozido } & (\text { ) }\end{array}$ & \\
\hline $\begin{array}{l}\text { Couve } \\
\text { manteiga }\end{array}$ & & & & & & & $\begin{array}{ll}\text { Crua } & (\text { ) } \\
\text { Refogado } & (\text { ( ) } \\
\text { Cozido } & (\text { ) }\end{array}$ & \\
\hline Brócolis & & & & & & & $\begin{array}{ll}\text { Cura } & (\text { ) } \\
\text { Refogado } & ()^{\prime} \\
\text { Cozido } & (\text { ) }\end{array}$ & \\
\hline Escarola & & & & & & & $\begin{array}{ll}\text { Crua } & (\text { ) } \\
\text { Refogado } & ()^{\prime} \\
\text { Cozido } & (\text { ) } \\
\end{array}$ & \\
\hline Espinafre & & & & & & & $\begin{array}{ll}\text { Crua } & (\text { ) } \\
\text { Refogado } & (() \\
\text { Cozido } & (\text { ) }\end{array}$ & \\
\hline \multicolumn{9}{|l|}{ Alface } \\
\hline Aveia & & & & & & & & \\
\hline
\end{tabular}


Anexo V - Valores da ingestão diária de vitaminas $B_{6}, B_{12} e$ ácido fólico por indivíduos da zona urbana e rural.

\begin{tabular}{c|c|c|c|c|c|c|c}
\hline \multirow{2}{*}{$\begin{array}{c}\text { Parâmetros } \\
\text { Estudados }\end{array}$} & \multicolumn{3}{c|}{ Urbana } & \multicolumn{3}{c|}{ Rural } & \multirow{2}{*}{$p$} \\
\cline { 2 - 7 } & Média & DP & EPM & Média & DP & EPM & \\
\hline Vitamina $\mathrm{B}_{6}(\mathrm{mg} / \mathrm{dia})$ & 2,14 & 3,62 & 0,39 & 0,47 & 0,42 & 0,046 & $0,00^{\star}$ \\
\hline Vitamina $\mathrm{B}_{12}(\mu \mathrm{g} / \mathrm{dia})$ & 5,77 & 8,25 & 0,90 & 6,63 & 7,25 & 0,780 & 0,473 \\
\hline Folato $(\mu \mathrm{g} / \mathrm{dia})$ & 73,53 & 62,32 & 6,84 & 58,57 & 50,48 & 5,44 & $0,041^{*}$ \\
\hline
\end{tabular}

$* p<0.05$ 
Anexo VI - Médias dos níveis plasmáticos das vitaminas $B_{6}$ e $B_{12}$ ácido fólico, Hcy, TG, colesterol total, VLDL, LDL e HDL, dos indivíduos das zonas urbana e rural.

\begin{tabular}{|c|c|c|c|c|c|}
\hline \multirow{2}{*}{$\begin{array}{l}\text { Parâmetros } \\
\text { estudados }\end{array}$} & \multicolumn{2}{|c|}{ Urbano } & \multicolumn{2}{|c|}{ Rural } & \multirow[t]{2}{*}{$p$} \\
\hline & Média & DP & Média & DP & \\
\hline Vitamina $B_{6}(\eta \mathrm{mol} / \mathrm{L})$ & 0.187 & 0,06 & 0.16 & 0,05 & $0,000^{*}$ \\
\hline Vitamina $\mathrm{B}_{12}(\mathrm{pg} / \mathrm{mL})$ & 350,08 & 87,10 & 386,01 & 149,53 & 0,057 \\
\hline Folato $(\eta \mathrm{mol} / \mathrm{L})$ & 18.62 & 3.60 & 8.85 & 4,27 & $0,000^{*}$ \\
\hline Hcy $(\mu \mathrm{mol} / \mathrm{L})$ & 12,82 & 5,58 & 16,56 & 9,22 & $0,002^{\star}$ \\
\hline $\mathrm{TG}(\mathrm{mg} / \mathrm{dL})$ & 100,86 & 49,88 & 141,37 & 73,96 & $0,000^{*}$ \\
\hline Colesterol (mg/dL) & 192,82 & 30,96 & 173,96 & 34,29 & $0,000^{*}$ \\
\hline VLDL(mg/dL) & 20,17 & 9,97 & 28,27 & 14,79 & $0,000^{*}$ \\
\hline $\mathrm{LDL}(\mathrm{mg} / \mathrm{dL})$ & 131,53 & 30,85 & 107,10 & 34,81 & $0,000^{*}$ \\
\hline HDL-colesterol (mg/dL) & 41,11 & 12,27 & 38,58 & 23,47 & 0,380 \\
\hline
\end{tabular}

${ }^{*} p<0.05$ 


\section{Anexo VII - Valores de Referências para os niveis plasmáticos das Vitaminas $B_{6}, B_{12}$ e Ácido Fólico bem como os níveis desejáveis dos lipidios TG, Colesterol, LDL, e HDL}

\begin{tabular}{r|c}
\hline Vitamina $B_{6}(\eta \mathrm{mol} / \mathrm{L})$ & $0,73-1,38$ \\
\hline Vitamina $\mathrm{B}_{12}(\mathrm{pg} / \mathrm{mL})$ & $211-911$ \\
\hline Ácido Fólico $(\eta \mathrm{mol} / \mathrm{L})$ & $2,5-45.4$ \\
\hline $\mathrm{TG}(\mathrm{mg} / \mathrm{dL})$ & $<200$ \\
\hline Colesterol total $(\mathrm{mg} / \mathrm{dL})$ & $<200$ \\
\hline LDL-colesterol(mg/dL) & $<130$ \\
\hline HDL-colesterol $(\mathrm{mg} / \mathrm{dL})$ & $>55$ (homens) \\
\end{tabular}

